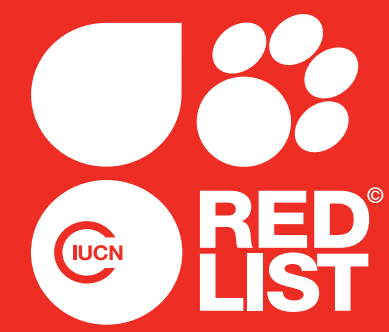

\title{
THE CONSERVATION STATUS AND DISTRIBUTION OF THE BREEDING BIRDS OF THE ARABIAN PENINSULA
}

Compiled by Andy Symes, Joe Taylor, David Mallon, Richard Porter, Chenay Simms and Kevin Budd

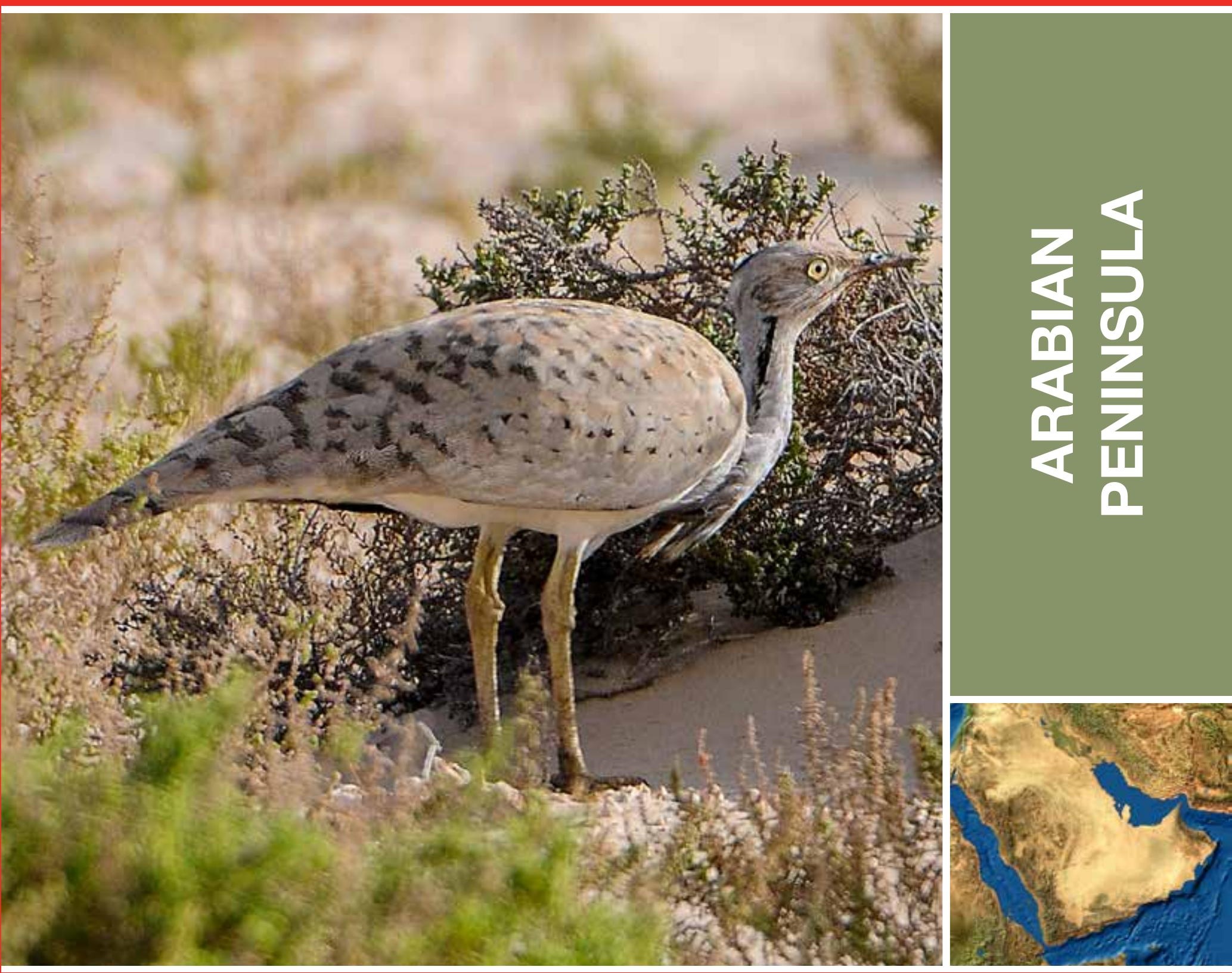

The IUCN Red List of Threatened Species ${ }^{\mathrm{TM}}$ - Regional Assessment

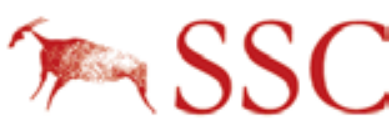

Species Survival Commission
22 Birdlife INTERNATIONAL
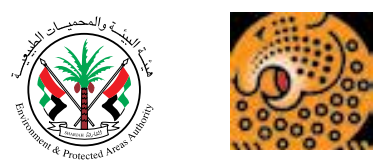


\section{About IUCN}

IUCN, International Union for Conservation of Nature, helps the world find pragmatic solutions to our most pressing environment and development challenges.

IUCN's work focuses on valuing and conserving nature, ensuring effective and equitable governance of its use, and deploying nature-based solutions to global challenges in climate, food and development. IUCN supports scientific research, manages field projects all over the world, and brings governments, NGOs, the UN and companies together to develop policy, laws and best practice.

IUCN is the world's oldest and largest global environmental organization, with almost 1,300 government and NGO Members and more than 15,000 volunteer experts in 185 countries. IUCN's work is supported by almost 1,000 staff in 45 offices and hundreds of partners in public, NGO and private sectors around the world. www.iucn.org

\section{About the Species Survival Commission}

The Species Survival Commission (SSC) is the largest of IUCN's six volunteer commissions with a global membership of around 7,500 experts. SSC advises IUCN and its members on the wide range of technical and scientific aspects of species conservation, and is dedicated to securing a future for biodiversity. SSC has significant input into the international agreements dealing with biodiversity conservation.

\section{About BirdLife International}

BirdLife International is the world's largest nature conservation Partnership. BirdLife is widely recognised as the world leader in bird conservation. Rigorous science informed by practical feedback from projects on the ground in important sites and habitats enables us to implement successful conservation programmes for birds and all nature.

\section{About the Environment and Protected Areas Authority}

The Environment and Protected Areas Authority (EPAA), Sharjah is charged with managing and protecting the indigenous fauna, flora, landscapes and associated cultural heritage in the Emirate of Sharjah.

The EPAA is also committed to addressing the greater ecological issues facing the region and has organised regional conservation workshops since 2000. These workshops, hosted by the Breeding Centre for Endangered Arabian Wildlife, have become a fixture and attract representatives from all over the region. They add their own expertise and discuss problems, concerns and, if possible, develop a conservation strategy.

The workshops have now gone to the next level in cooperation with the IUCN Red List office and starting to produce IUCN Red List regional assessments of chosen taxa. 


\section{THE CONSERVATION STATUS AND DISTRIBUTION OF THE BREEDING BIRDS OF THE ARABIAN PENINSULA}

Compiled by Andy Symes, Joe Taylor, David Mallon, Richard Porter, Chenay Simms and Kevin Budd 
The designation of geographical entities in this book, and the presentation of material, do not imply the expression of any opinion whatsoever on the part of IUCN or other participating organizations, concerning the legal status of any country, territory, or area, or of its authorities, or concerning the delimitation of its frontiers or boundaries.

The views expressed in this publication do not necessarily reflect those of IUCN or other participating organizations.

Published by: IUCN, Gland, Switzerland and Cambridge, UK and the Environment and Protected Areas Authority, Government of Sharjah, UAE.

Copyright: @ 2015 International Union for Conservation of Nature and Natural Resources Reproduction of this publication for educational or other non-commercial purposes is authorized without prior written permission from the copyright holder provided the source is fully acknowledged.

Reproduction of this publication for resale or other commercial purposes is prohibited without prior written permission of the copyright holder.

Red List logo: @ 2008

ISBN: $\quad 978-2-8317-1751-7$

DOI: $\quad$ http://dx.doi.org/10.2305/IUCN.CH.2015.MRA.5.en

Citation: $\quad$ Symes, A., Taylor, J., Mallon, D., Porter, R., Simms, C. and Budd, K. (2015). The Conservation Status and Distribution of the Breeding Birds of the Arabian Peninsula. Cambridge, UK and Gland, Switzerland: IUCN, and Sharjah, UAE: Environment and Protected Areas Authority.

Cover photo: Houbara bustard Chlamydotis undulata. @ A Ahmed Al Ali.

All photographs used in this publication remain the property of the original copyright holder. Photographs should not be reproduced or used in other contexts without written permission from the copyright holder.

Available from: Environment and Protected Areas Authority, c/o Breeding Centre for Endangered Arabian Wildlife, PO Box 29922, Sharjah, United Arab Emirates, Email: bceaw@bceaw.ae

Printed in the United Arab Emirates 


\section{Contents}

Acknowledgements

Executive Summary

$\begin{array}{ll}\text { 1. Background } & 1\end{array}$

1.1 The Assessment Region 1

1.2 Birds of Arabia 3

1.3 Conservation status $\quad 4$

1.4 Objectives of the assessment 4

$\begin{array}{ll}\text { 2. Assessment methodology } & 7\end{array}$

$\begin{array}{ll}2.1 \text { Global and regional assessments } & 7\end{array}$

$\begin{array}{ll}2.2 \text { Taxonomic scope } & 7\end{array}$

$\begin{array}{ll}2.3 \text { Preliminary assessments and review process } & 7\end{array}$

$\begin{array}{lr}\text { 3. Results } & 8\end{array}$

4. Conclusions 14

4.1 Conservation priorities 14

4.2 Application of project outputs $\quad 15$

$\begin{array}{ll}4.3 \text { Future work } & 15\end{array}$

$\begin{array}{ll}\text { 5. References and further reading } & 17\end{array}$

$\begin{array}{llr}\text { Appendix 1. } & \text { Participants List } & 19\end{array}$

Appendix 2. Regional Red List assessments of the breeding birds of the Arabian Region 20

$\begin{array}{lll}\text { Appendix 3. Endemic, near-endemic and threatened species distribution maps } & 38\end{array}$ 



\section{Acknowledgements}

We would like to thank His Highness Sheikh Dr Sultan bin Mohammed Al Qasimi, Member of the Supreme Council and Ruler of Sharjah, for his support and guidance, and for continuing to champion biodiversity conservation in Arabia; without which the success of this workshop would not have been possible.

We are grateful to our host organizations, the Environment and Protected Areas Authority (EPAA), Government of Sharjah and the Breeding Centre for Endangered Arabian Wildlife (BCEAW) for providing logistical and administrative support and making sure the communications and evaluation workshop ran smoothly. We would especially like to thank Ms. Hana Al Suwaidi (Chairperson, EPAA), and Mr Paul Vercammen (Operations Manager, BCEAW). Workshop facilitators in Sharjah were Andy Symes, Joe Taylor, and David Mallon.

All of IUCN's global Red Listing processes rely on the willingness of scientists to contribute and pool their collective knowledge to make the most reliable estimates of species conservation status. Without their enthusiastic commitment to species conservation, this kind of regional overview would not be possible.

We would like to thank the following people who gave their time and valuable expertise to evaluate all of the assessments at the workshop held in Sharjah, asking forgiveness from anyone whose name is inadvertently omitted or misspelled: Jeruel Cabadonga Aguhob, Ahmed Al Ali, Husam Al-Asfoor, Mahmood Alabri, Waheed Abdullah Al Fazari, Sharif al Jbour, Masa'a Mahdi Al Jumaily, Khalid Al Rasbi, Monif Al Rashidi, Omar Al-Saghier, Hassan Zain Al Sharif, Nabegh Asswad, Abdullah As Suhaibani, Adel Mohammed Al Awadhi, Salah Behbehani, Laith el-Moghrabi, Richard Hornby, Mike Jennings, Maher Kabshawi, Reza Khan, Shahid Bashir Khan, Dr. Pathan, Mike Pope, Richard Porter, Cromwell Purchase, Mudhafar Salim, Boudjema Samraoui, Mohammed Shobrak, and Nick Williams. Funding for data compilation, workshop facilitation and data editing was provided through the EPAA and BirdLife International.

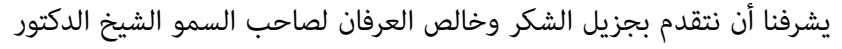

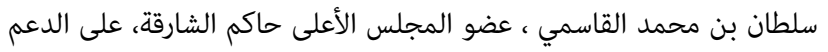

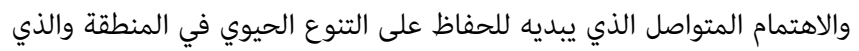

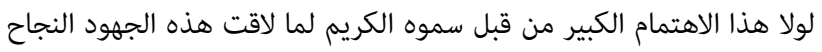
في الحفاظ على التنوع الحيوي.

كما أننا نتقدم بالشكر إلى هيئة البيئة والمحميات الطبيعية في إمارة الشارقة

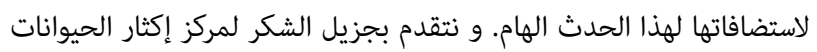

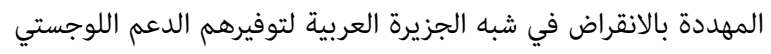

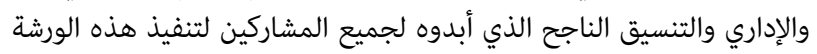

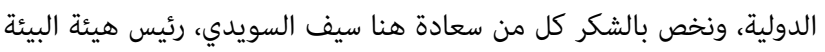

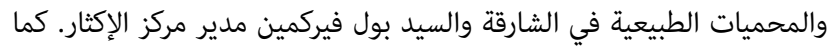
نشكر منسقي الورشة، آندي سيمس، جو تايلور، و ديفيد مالون.

أن جميع العلماء والخبراء في القائمة الحمراء للأنواع المهددة بالانقراض الحاض

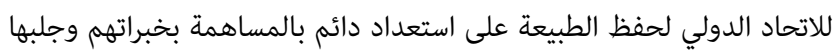

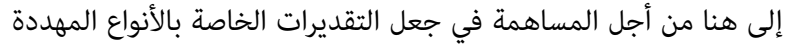
بالانقراض أكثر موثوقية والتي بدونها سيتعذر علينا جمع البيانات والتأكد منها.

وكذلك نشكر جميع المساهمين في الورشة الذين قدموا خبراتهم ووقتهم

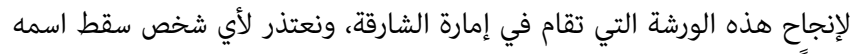

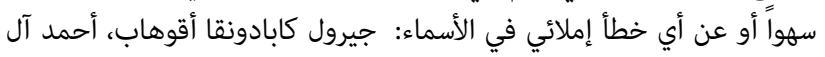

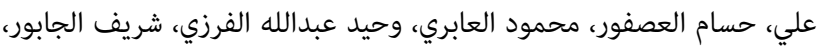

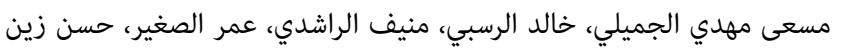

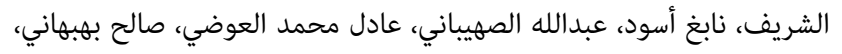

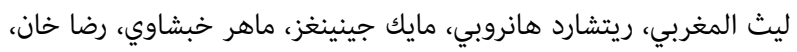

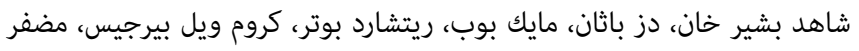

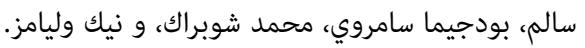

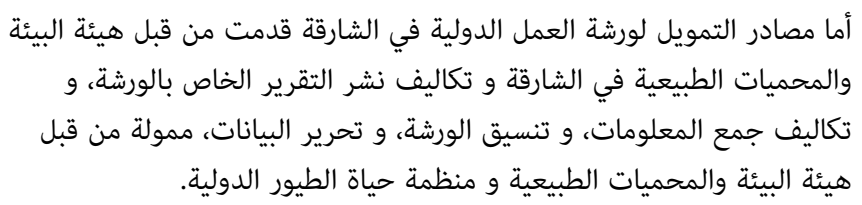





\section{Executive Summary}

The project region, defined here to include Arabian Peninsula, plus Iraq, Syria, and Lebanon, contains a diversity of desert, mountain, and wetland habitats and lies at the crossroads of the Rift Valley/Red Sea and the East Asia/East Africa flyways. Bird species richness is high and 357 species are known to breed in the region. Of these, 28 species were excluded from this assessment as their occurrence in the region is marginal. The conservation status of the remaining 329 species was assessed through the application of the IUCN Red List Categories and Criteria at the global and regional scales during a workshop held at the Breeding Centre for Endangered Arabian Wildlife (BCEAW) in Sharjah, UAE from 3-7 February 2013 in cooperation with BirdLife International.

Overall, species richness is highest around the edges of the Arabian Peninsula, especially the south-western mountains and Dhofar, with the least diverse area being the Rub' al Khali (or Empty Quarter) and the areas of endemism generally follow the same pattern. A total of 35 species (10.6\%) are endemic or near-endemics (greater than $70 \%$ of global range) to the region; the island of Socotra has an especially high number of endemic species (10). Nearly one quarter (24\%) of the regions 329 breeding bird species are considered to be regionally Threatened or Near Threatened and one, the Ostrich (Struthio camelus), is Regionally Extinct.

Habitat loss remains the overriding threat to the breeding birds within the region, but some species particularly the Falconiformes and Gruiformes are both sought-after and heavily exploited by falconers.

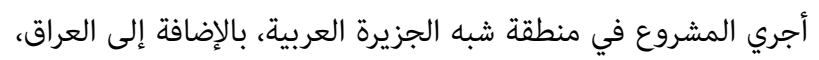

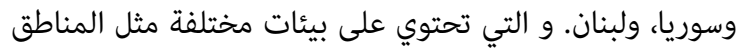

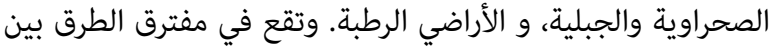

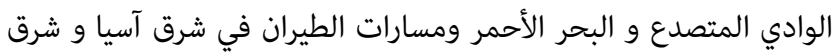

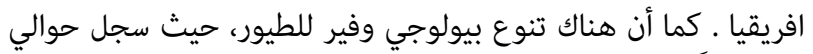

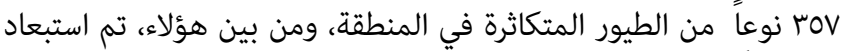

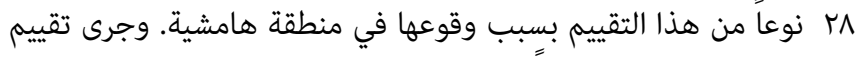

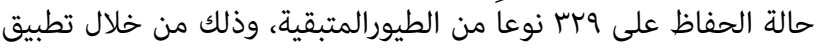

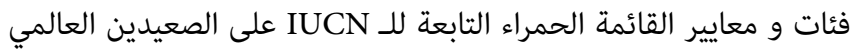

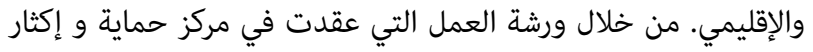

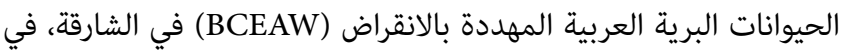

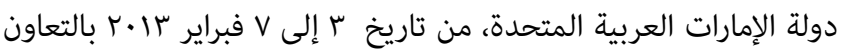
مع منظمة حياة الطيور الدولية.

على الأغلب، وفرة التنوع البيولوجي للطيور هي الأكثف على أطراف شبه

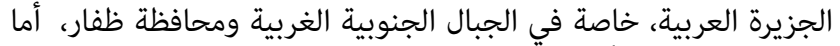

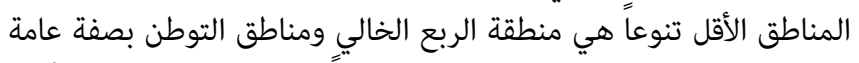

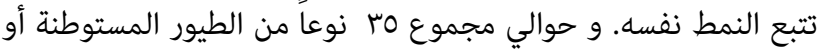

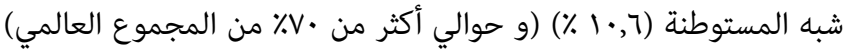

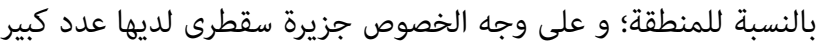

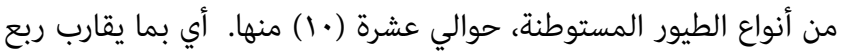

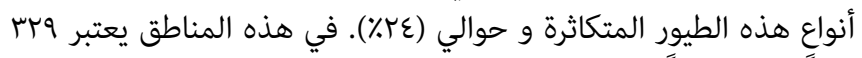

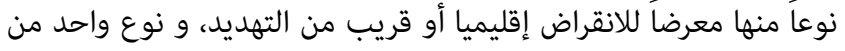

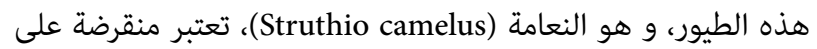

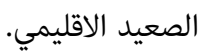
ولا يزال عامل فقدان الموائل المهدد الرئيسي للطيور المتكاثرة

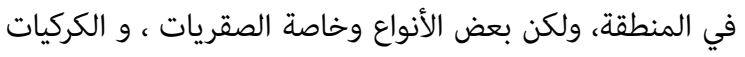

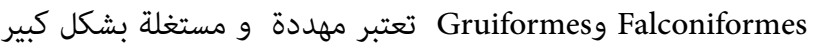
من قبل الصقارين. 



\section{Background}

\subsection{The Assessment Region}

The assessment region covered the whole of the Arabian Peninsula, plus Iraq, Syria and Lebanon, including offshore islands and the Socotra archipelago (Figure. 1). The total area covered exceeds $3,000,000 \mathrm{~km}^{2}$.

Most of the interior of the region is composed of sand and gravel deserts, arid steppes and rocky plateaus intersected by numerous wadis. The largest of these are Wadi Rum in Jordan and the Wadi Hadhramaut-Wadi Masilah system in southern Yemen. Sand dunes make up large areas, with the Rub al Khali (Empty Quarter) in the south-east occupying about 640,000 $\mathrm{km}^{2}$. Black basalt lava flows (harrat) cover about $30,000 \mathrm{~km}^{2}$ in northern Saudi Arabia and adjacent parts of Syria and Jordan.

Mountains fringe the entire region except for the north-east coast of the Gulf. The western mountains run along the coast and rise steeply from the sea, shelving more gradually towards the desert interior. They reach their highest point at Jebel An Nabi Shu'ayb $(3,666 \mathrm{~m})$ in Yemen. The southern part of this range, in south-west Saudi Arabia and Yemen, receives summer rainfall and the western escarpment is intensively cultivated by means of terraced fields and cut by many steep wadis, some of which contain some water throughout the year and are partially wooded, with species of Ficus, Cordia, Breonardia and Tamarindus. At higher elevations, some patches of open

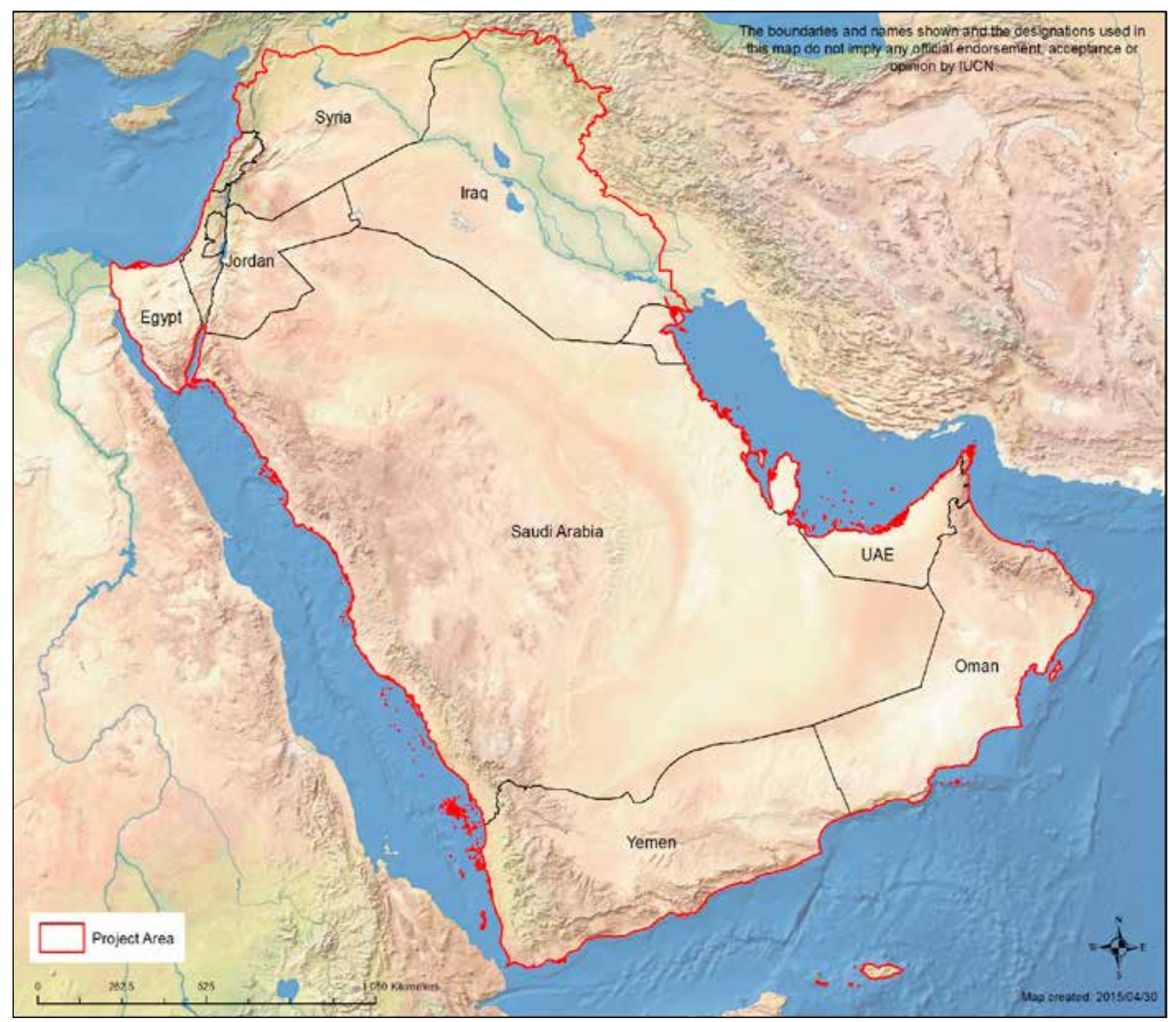

Figure 1. The Assessment Region as defined through the current report. 
juniper Juniperus procera woodland remain. The mountains of Dhofar, southern Oman and the Mahra region of eastern Yemen attain elevations of 1,400-1,800 $\mathrm{m}$ and also receive rain from the summer monsoon. Dense woodland on their seaward slopes contains Anogeissus dhofarica, Commiphora habessinica and frankincense Boswellia sacra trees. Between Dhofar and the SW mountains lies an extensive limestone plateau, the jol.

The Hajar Mountains of Oman and UAE stretch along the south-east coast for about $700 \mathrm{~km}$ between the Musandam Peninsula and Ras al Hadd. Their highest point, on Jebel Al Akhdar, reaches $3,009 \mathrm{~m}$. The northern edge of the region is bordered by the Zagros Range, reaching 3,611 $\mathrm{m}$ in the Kurdistan region of Iraq. A strip of lower hills belonging to the Mediterranean biome runs south along the western edge of the region from the Turkish border through Lebanon, Syria and Jordan. The vegetation consists of Mediterranean scrub, Pine Pinus spp. forests and the well-known cedar of Lebanon Cedrus libani.

Salt flats (sabkha) occur on coasts and in places inland. Narrow coastal strips - the Tihama in the south-west and Batinah in Oman - contain extensive areas of agriculture. Mangroves are an important but declining habitat especially along the Gulf and Red Sea coasts.

Apart from the Tigris and Euphrates rivers of Syria and Iraq, and the Orontes and Jordan rivers in the west, permanent water is restricted to a few mountain wadis. Temporary streams and pools occur after rainfall. The marshes of southern Iraq are the region's major wetland. Draining these marshes for political reasons reduced them to about $10 \%$ of their original extent by 2003 . Reflooding since then has restored about $55 \%$ of the area covered in the 1970s.

The Damaniyat, Farasan, and Hanish Islands as well as many smaller islets in the Gulf and Red Sea provide important breeding habitat for seabirds and other species. There are important stopover and wintering sites for migrant and wintering shorebirds and waterbirds along the coasts, notably Barr al Hikman in Oman.

Vegetation over most the region is generally sparse and low, though many wadis have open Acacia-Commiphora woodland, and several species of Acacia and Zizyphus are widespread. In Oman and UAE, groves of Prosopis cineraria trees (ghaf) occur. Overgrazing by livestock has adversely affected much of the original natural vegetation.

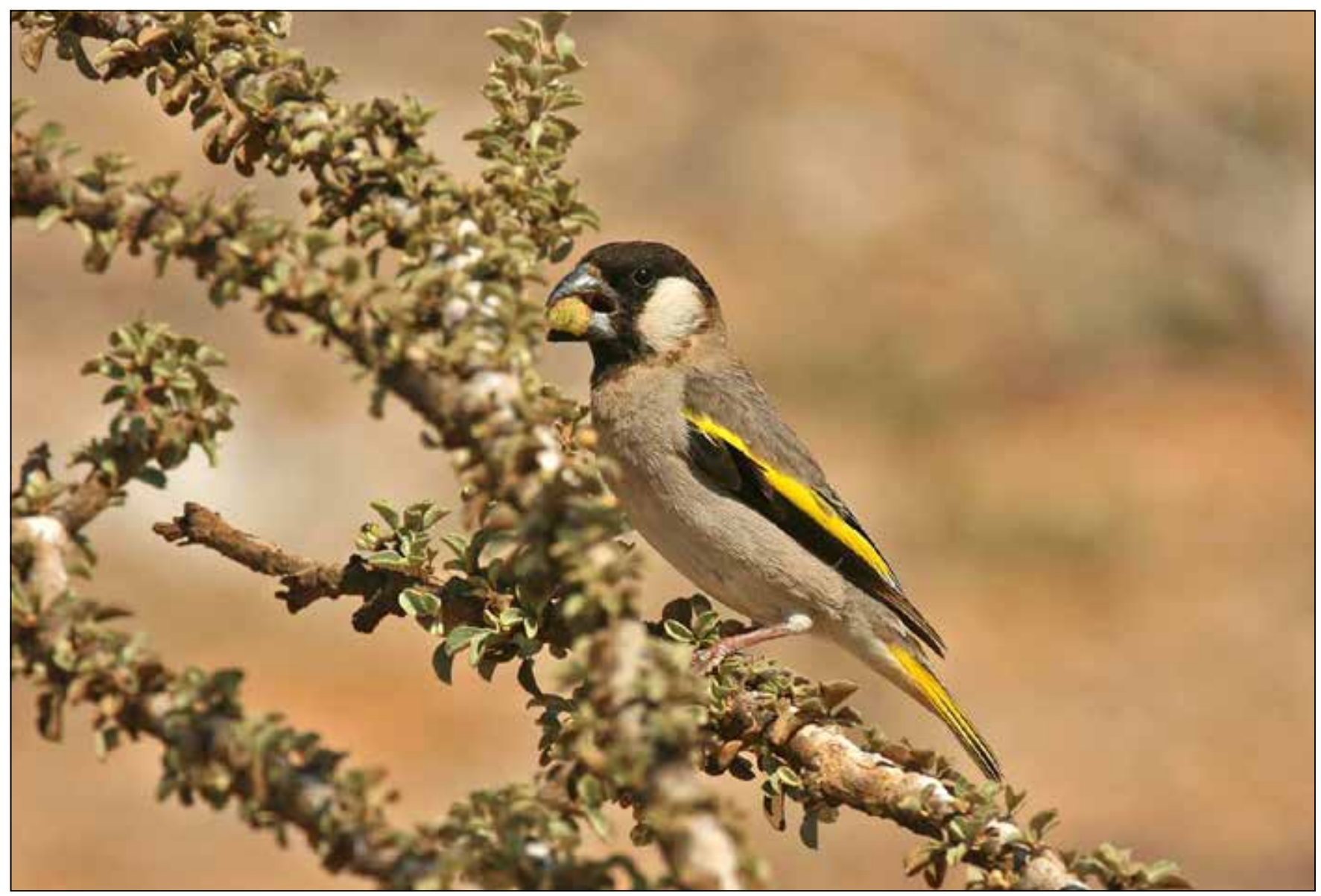

Endemic to Socotra but widespread and stable the Socotra Grosbeak Rhynchostruthus socotranus is classified as Least Concern. (C) Richard Porter. 
The Arabian Region lies at the junction of three biogeographic realms: western Palearctic, Afrotropical, and Oriental, which is reflected in the composition of the flora and fauna, including the birds. The south-west mountains, Dhofar and Hadhramaut form part of two global biodiversity hotspots Horn of Africa and Eastern Afromontane (Mittermeier et al. 2004).

\subsection{Birds of Arabia}

There are 357 species of birds breeding within the assessment region. Of these, 28 species were excluded from this study as their distribution in the region is marginal. The remaining 329 species of breeding birds belong to 20 major groups, with the vast majority (48.9\%) belonging to the order Passeriformes (Table 1).

Endemism is relatively low with only 26 (7.9\%) species endemic to Arabia, as defined here: 14 of these species occur on the mainland, 10 on the Socotra archipelago and two are seabirds that are breeding endemics, including Jouanin's Petrel Bulweria fallax, only on Socotra. There is a concentration of endemic species in the highlands of SW Saudi Arabia and
Yemen with some also occurring in the Dhofar mountains of Oman. Arabian Partridge Alectoris melanocephala and Arabian Wheatear Oenanthe lugentoides are more widespread and two species are restricted to the north of the region Basra Reed Warbler Acrocephalus griseldis in the Iraq marshes and Syrian Serin Serinus syriacus in the western hills: both of these are assessed as Endangered.

A further nine species are considered near-endemics (defined as having $\geq 70 \%$ of their global range in the region), including Crab Plover Dromas ardeola as a breeding near-endemic. Proposed taxonomic splits currently under consideration may increase the number of endemic and near-endemic forms: For example Green Bee-eater Merops orientalis, Sinai Rosefinch Carpodacus synoicus, and Cinereous Bunting Emberiza cineracea. The same taxonomic review may also result in Barbary Falcon Falco pelegrinoides being lumped with Peregrine F. peregrinus. Table 2 lists the endemic and near-endemic species and Appendix 3 shows the distributions of endemic and near-endemic species occurring in the region.

It is important to note that there is a high proportion of regional endemics and near-endemics within the small number of species belonging to the orders; Procellariiformes

Table 1. Diversity and endemism in breeding birds orders in the Arabian region

\begin{tabular}{|c|c|c|c|c|}
\hline Order & No. of species & $\begin{array}{c}\text { Number of } \\
\text { endemics }\end{array}$ & $\begin{array}{c}\text { Number of } \\
\text { near-endemics }\end{array}$ & Percentage endemic \\
\hline Struthioniformes & 1 & 0 & 0 & $0.0 \%$ \\
\hline Podicipediformes & 2 & 0 & 0 & $0.0 \%$ \\
\hline Procellariiformes & 2 & 1 & 0 & $50.0 \%$ \\
\hline Pelecaniformes & 7 & 1 & 0 & $14.3 \%$ \\
\hline Ciconiiformes & 18 & 0 & 0 & $0.0 \%$ \\
\hline Phoenicopteriformes & 1 & 0 & 0 & $0.0 \%$ \\
\hline Anseriformes & 5 & 0 & 0 & $0.0 \%$ \\
\hline Falconiformes & 26 & 1 & 0 & $3.8 \%$ \\
\hline Galliformes & 9 & 2 & 1 & $33.3 \%$ \\
\hline Gruiformes & 2 & 0 & 0 & $0.0 \%$ \\
\hline Charadriiformes & 34 & 0 & 1 & $2.9 \%$ \\
\hline Pterocliformes & 6 & 0 & 0 & $0.0 \%$ \\
\hline Columbiformes & 11 & 0 & 0 & $0.0 \%$ \\
\hline Cuculiformes & 5 & 0 & 0 & $0.0 \%$ \\
\hline Strigiformes & 12 & 1 & 1 & $16.7 \%$ \\
\hline Caprimulgiformes & 4 & 0 & 0 & $0.0 \%$ \\
\hline Apodiformes & 6 & 0 & 0 & $0.0 \%$ \\
\hline Coraciiformes & 14 & 0 & 0 & $0.0 \%$ \\
\hline Piciformes & 3 & 1 & 0 & $33.3 \%$ \\
\hline \multirow[t]{2}{*}{ Passeriformes } & 161 & 19 & 6 & $15.5 \%$ \\
\hline & 329 & 26 & 9 & $10.6 \%$ \\
\hline
\end{tabular}


(tube-nosed seabirds) (2 species, 1 endemic), Galliformes (chicken-like birds) (9 species, 3 endemic), and Piciformes (woodpeckers and relatives) (3 species, 1 endemic).

\subsection{Conservation status}

One of the most widely used indicators for assessing the health of ecosystems and their biodiversity is the conservation status of plants and animals. It is also an important component of priority-setting exercises for species conservation. At the global level, the best source of information on the conservation status of plants and animals is the IUCN Red List of Threatened Species (IUCN, 2012). Taxa that have been evaluated using the IUCN Red List Categories and Criteria: Version 3.1 (IUCN, 2001) (http://www.iucnredlist.org/technical-documents/ categories-and-criteria) are included on the Red List, along with details of their taxonomy, distribution information (including a range map), population status, habitat and ecology, threats, utilization and conservation measures in place and needed. The IUCN Red List Categories and Criteria is designed to determine the relative risk of extinction, with the main purpose of highlighting those taxa that are facing a higher risk of global extinction (i.e., those listed as Critically Endangered, Endangered and Vulnerable). Species in these three categories are collectively referred to as 'threatened.

\subsection{Objectives of the assessment}

This assessment has two main objectives:

- To assist in regional conservation planning by assessing the status and distribution of all species occurring within the region; and

- To develop a network of regional experts to support future assessments and the updating of the information on these species.

The assessment provides two main direct outputs:

- A report on the status of the breeding birds of the Arabian region, including a Red List assessment of all the species, an identification of the main threats for each species, and a spatial representation of the centres of species richness and threats;

- A database that provides a baseline for monitoring the status of the breeding birds of Arabian Peninsula. The data presented in this report and the booklet provides a snapshot based on available knowledge at the time of writing.

The database will continue to be updated and made freely and widely available. BirdLife International will ensure wide dissemination of this data to relevant decision makers, NGOs, and scientists to inform the implementation of conservation actions on the ground.

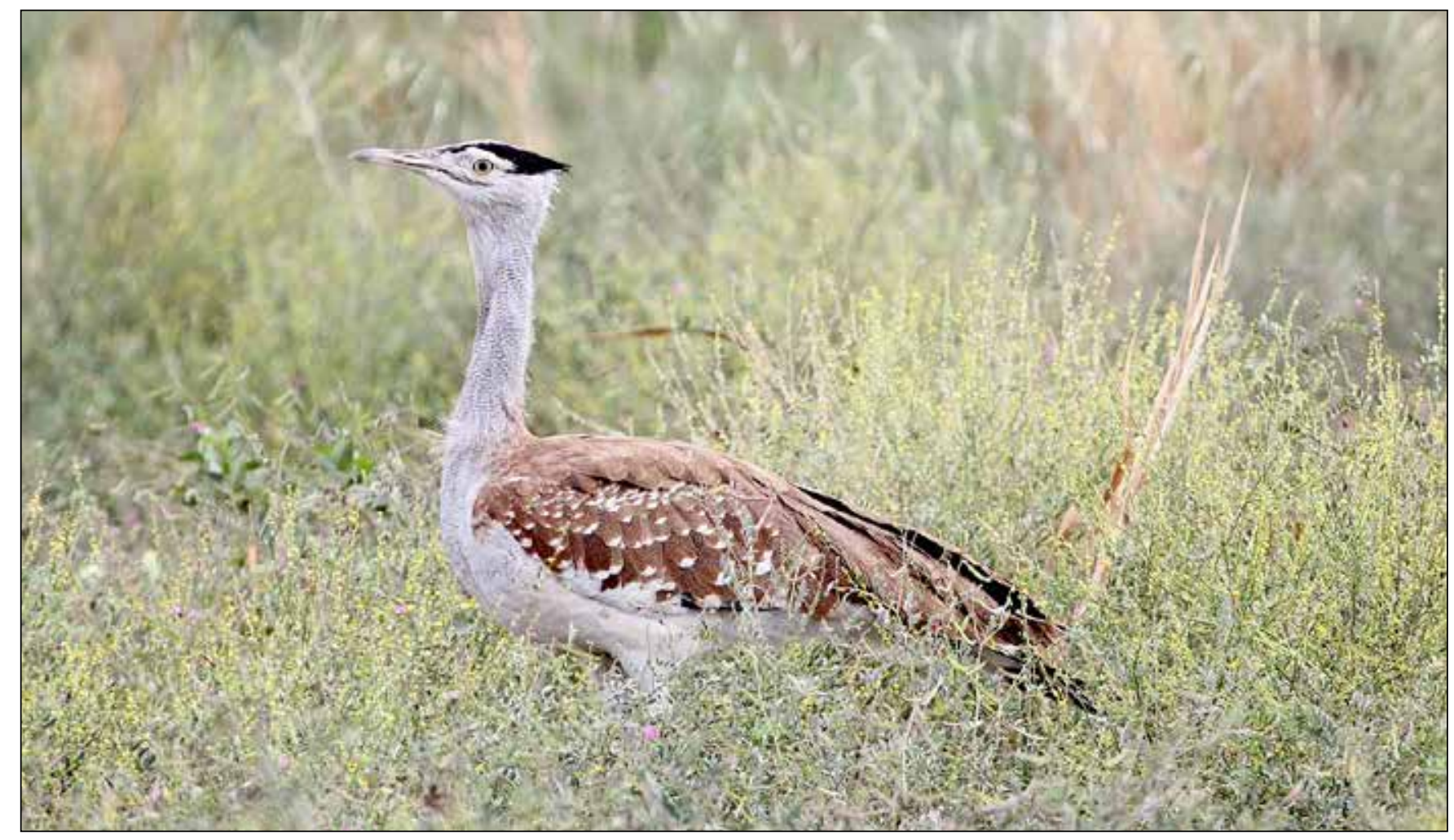

Arabian Bustard Ardeotis arabs is Critically Endangered due to a very rapid population decline and with fewer than 50 breeding females remaining . (c) Richard Porter. 
Table 2. Endemic and near-endemic breeding bird species in the assessment region.

\begin{tabular}{|c|c|c|c|c|}
\hline Common Name & Species name & $\begin{array}{l}\text { Regional Red List } \\
\text { Category \& Criteria }\end{array}$ & Population Trend & $\begin{array}{c}\% \text { global } \\
\text { range }\end{array}$ \\
\hline \multicolumn{5}{|l|}{ Mainland endemics } \\
\hline Arabian Partridge & Alectoris melanocephala & $\mathrm{LC}$ & Increasing & 100 \\
\hline Philby's Partridge & Alectoris philbyi & $\mathrm{LC}$ & Decreasing & 100 \\
\hline Arabian Woodpecker & Dendrocopos dorae & $\mathrm{VU} A 2 \mathrm{ac}+\mathrm{A} 3 \mathrm{c}+\mathrm{A} 4 \mathrm{c}$ & Decreasing & 100 \\
\hline Arabian Wheatear & Oenanthe lugentoides & $\mathrm{LC}$ & Decreasing & 100 \\
\hline Yemen Thrush & Turdus menachensis & $\mathrm{LC}$ & Decreasing & 100 \\
\hline Yemen Accentor & Prunella fagani & NT & Decreasing & 100 \\
\hline Basra Reed-warbler & Acrocephalus griseldis & EN B2ab(i,ii,iii,iv,v) & Unknown & 100 \\
\hline Yemen Warbler & Sylvia buryi & NT & Decreasing & 100 \\
\hline Syrian Serin & Serinus syriacus & $\mathrm{EN} \mathrm{A} 2 \mathrm{acd}+\mathrm{A} 3 \mathrm{~cd}+\mathrm{A} 4 \mathrm{acd}$ & Decreasing & 100 \\
\hline Olive-rumped Serin & Serinus rothschildi & $\mathrm{LC}$ & Decreasing & 100 \\
\hline Yemen Serin & Serinus menachensis & $\mathrm{LC}$ & Increasing/stable & 100 \\
\hline Yemen Linnet & Carduelis yemenensis & $\mathrm{LC}$ & Stable & 100 \\
\hline Arabian Waxbill & Estrilda rufibarba & $\mathrm{LC}$ & Stable/decreasing & 100 \\
\hline Arabian Grosbeak & Rhynchostruthus percivali & NT & Decreasing & 100 \\
\hline \multicolumn{5}{|l|}{ Breeding endemic seabirds } \\
\hline Socotra Cormorant & Phalacrocorax nigrogularis & VU A2acd $+3 c d+4 a c d$ & Decreasing & 100 \\
\hline Jouanin's Petrel & Bulweria fallax & NT & Unknown & 100 \\
\hline \multicolumn{5}{|l|}{ Socotra endemics } \\
\hline Socotra Buzzard & Buteo socotraensis & VU D1 & Stable & 100 \\
\hline Socotra Scops Owl & Otus socotranus & $\mathrm{LC}$ & Stable/increasing & 100 \\
\hline Socotra Starling & Onychognathus frater & $\mathrm{LC}$ & Stable & 100 \\
\hline Socotra Sunbird & Nectarinia balfouri & $\mathrm{LC}$ & Stable/increasing & 100 \\
\hline Island Cisticola & Cisticola haesitatus & NT & Stable & 100 \\
\hline Socotra Warbler & Incana incana & $\mathrm{LC}$ & Stable & 100 \\
\hline Socotra Sparrow & Passer insularis & $\mathrm{LC}$ & Stable & 100 \\
\hline Abd Al Kuri Sparrow & Passer hemileucus & VU D1 & Stable & 100 \\
\hline Socotra Grosbeak & Rhynchostruthus socotranus & $\mathrm{LC}$ & Stable & 100 \\
\hline Socotra Bunting & Emberiza socotrana & NT & Stable & 100 \\
\hline \multicolumn{5}{|l|}{ Near-endemic species } \\
\hline Arabian Babbler & Turdoides squamiceps & $\mathrm{LC}$ & Increasing & 98.18 \\
\hline Tristram's Starling & Onychognathus tristramii & $\mathrm{LC}$ & Stable & 98.09 \\
\hline White-spectacled Bulbul & Pycnonotus xanthopygos & $\mathrm{LC}$ & Increasing & 91.44 \\
\hline Hume's Owl & Strix butleri & $\mathrm{LC}$ & Stable? & 86.34 \\
\hline Iraq Babbler & Turdoides altirostris & $\mathrm{LC}$ & Increasing & 86.08 \\
\hline Sand Partridge & Ammoperdix heyi & $\mathrm{LC}$ & Decreasing & 80.20 \\
\hline Arabian Golden Sparrow & Passer euchlorus & $\mathrm{LC}$ & Stable & 76.43 \\
\hline Crab Plover & Dromas ardeola & VU D1 & Decreasing & 72.27 \\
\hline Palestine Sunbird & Nectarinia osea & $\mathrm{LC}$ & Increasing & 70.72 \\
\hline
\end{tabular}




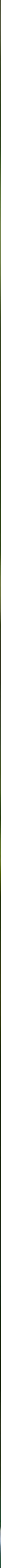




\section{Assessment methodology}

\subsection{Global and regional assessments}

This was primarily an assessment of the regional conservation status of all bird species breeding in the Arabian region. The status of each species was assessed according to the IUCN Red List Categories and Criteria. Version 3.1 (IUCN 2001) and the Guidelines for Application of IUCN Criteria at Regional Levels (IUCN 2003).

\subsection{Taxonomic scope}

All native bird species known to breed in the Arabian region were included in the assessment. Species that are vagrant or of marginal or uncertain occurrence, were classed as Not Applicable. Several local subspecies and forms have been recognized. Two of them, Asir Magpie Pica pica asirensis and Kalba Kingfisher Todiramphus chloris kalbensis, have also been given a separate assessment alongside the full species.

Non-native species that have established breeding populations derived from escapes, deliberate introductions or arrival on ships (Jennings 2010, Porter \& Aspinall 2010) were not individually assessed as part of this project. Some of these species are very invasive and damaging to indigenous biodiversity, notably the House Crow Corvus splendens and Common Myna Acridotheres tristis. For more details on non-native species in the Arabian Peninsula see Jennings (2010). The House Crow has since been eliminated from Socotra (Suleiman and Taleb 2010), an important measure in conserving the island's unique biodiversity. Several escaped cage birds have established populations, particularly in the UAE.

The list also includes 28 breeding species that were considered Not Applicable for regional assessment because their occurrence in the region is marginal or there are no recent confirmed records. One newly described species that was described after the workshop, Omani Owl Strix omanensis (Robb et al. 2013), was not assessed; this has since been shown to be Strix butleri ( Robb et al. 2015).

\subsection{Preliminary assessments and review process}

A provisional list of birds breeding in the region was compiled prior to the workshop by Andy Symes and Joe Taylor (BirdLife International) from the IUCN Red List database, together with information on their global Red List category, status, population trend, countries of occurrence, and proportion of global range in the region and generation length.

The provisional species list was reviewed at the beginning of the workshop and those species not confirmed as breeding in the region were omitted. The 357 species that remained were assessed by two working groups, with a final collective session held to resolve outstanding issues and assess the regionally endemic species.

Key supplementary information on distribution, status and population estimates were obtained from the Atlas of the Breeding Birds of Arabia (Jennings 2010) and the second edition of the Field Guide to the Birds of the Middle East (Porter \& Aspinall 2010). Recent checklists of the birds of Iraq (Salim et al. 2013) and Syria (Murdoch \& Betton 2008) were used as the basis for those countries. Up to date status reports were provided for Jordan (RSCN 2013) and Socotra (Porter and Suleiman 2013, 2014).

Following the workshop, the assessments were reviewed and supplementary information added from recent publications where appropriate and any remaining issues resolved through communications with workshop participants. 


\section{Results}

A full list of the breeding bird species from the Arabian Region, their regional IUCN Red List status, criteria, and a summary justification is given in Appendix 2. The list also includes 28 breeding species that were considered Not Applicable for regional assessment because their occurrence in the region is marginal or there are no recent confirmed records. The number of species in the different IUCN Red List Categories is shown in Figure 2 and Table 3. In summary, seven species were categorized as regionally Critically Endangered (CR), 21 species are Endangered (EN) and 21 Vulnerable (VU). Altogether, 49 species (c.15\%) fall into one of these three categories which are collectively regarded as 'threatened'. The distribution of threatened species is shown in Figure 4. A further 31 species are Near Threatened (NT) and 247 (c.75\%) of the 329 species assessed were Least Concern (LC), the lowest category of threat. One species (Ostrich) is Regionally Extinct and one (Eurasian Penduline-tit) is Data Deficient. Species classed as threatened (Critically Endangered, Endangered and Vulnerable) and Near Threatened are listed in Table 4.

Of the seven species categorized as regionally Critically Endangered (CR) two are falcons (Falco biarmicus and F. cherrug), which are highly sought-after for falconry, and two are bustards, including the iconic Houbara Chlamydotis

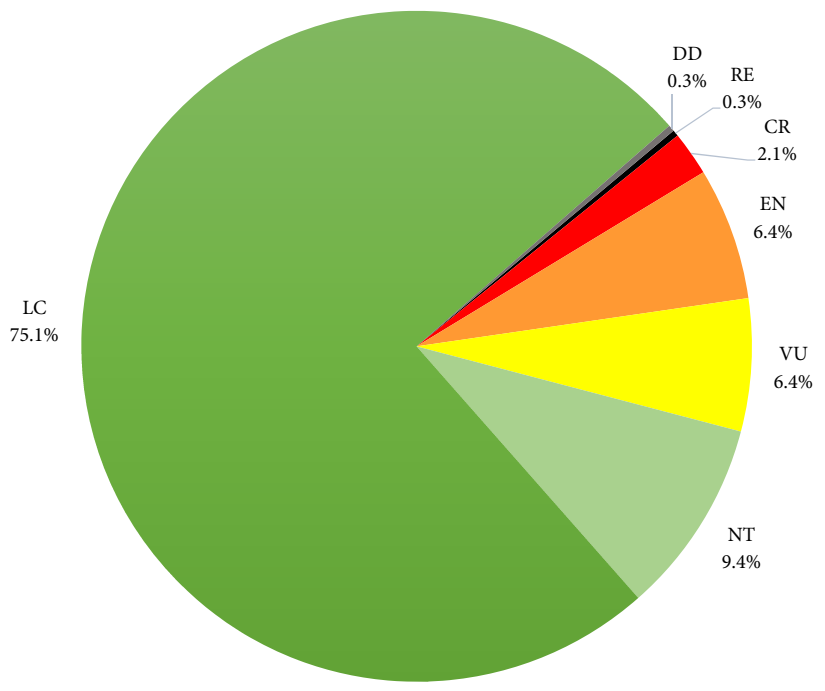

Figure 2. The number of species regionally assessed in the different Red List categories ( $\mathrm{RE}=$ Regionally Extinct; $\mathrm{CR}=$ Critically Endangered; DD = Data Deficient; EN = Endangered; VU = Vulnerable; NT = Near Threatened; LC = Least Concern).

undulata, which are heavily exploited, also by falconers.

Breeding birds of the Arabian region belong to 20 taxonomic orders and considerable differences exist among these groups in both species numbers as well as threatened status (see Table 5). Passeriformes constitute the majority of breeding birds. Pelecaniformes (71.4\%), Anseriformes (80\%), Falconiformes(65.4\%), and Gruiformes (100\%) are particularly threatened.

Table 3. Summary of the Red List status for all of the breeding birds of the Arabian region.

\begin{tabular}{lcc}
\hline & Global Red & Regional Red \\
IUCN Red List categories & List 2012 & List \\
\hline Extinct (EX) & 0 & 0 \\
Extinct in the Wild (EW) & 0 & 1 \\
Critically Endangered (CR) & 1 & 7 \\
Endangered (EN) & 4 & 21 \\
Vulnerable (VU) & 11 & 21 \\
Near Threatened (NT) & 10 & 31 \\
Least Concern (LC) & 302 & 247 \\
Data Deficient (DD) & 0 & 1 \\
Not Evaluated (NE) & 0 & 0 \\
\hline Total number of breeding birds assessed & $\mathbf{3 2 9}$ & $\mathbf{3 2 9}$ \\
\hline
\end{tabular}


Table 4. Threatened and Near Threatened breeding birds in the assessment region

\begin{tabular}{|c|c|c|c|c|c|}
\hline Common Name & Scientific Name & Order & $\begin{array}{l}\text { Regional } \\
\text { Status }\end{array}$ & Criteria & Endemic \\
\hline Northern Bald Ibis & Geronticus eremita & Ciconiiformes & $\mathrm{CR}$ & $\mathrm{D}, \mathrm{C} 2 \mathrm{a}(\mathrm{i}),(\mathrm{ii}), \mathrm{B} 1+2 \mathrm{ab}(\mathrm{v})$ & \\
\hline African Darter & Anhinga rufa & Pelecaniformes & CR & C2a(ii) & \\
\hline Lanner Falcon & Falco biarmicus & Falconiformes & $\mathrm{CR}$ & C2a(ii). EN A2,3,4, D1. & \\
\hline Saker Falcon & Falco cherrug & Falconiformes & $\mathrm{CR}$ & C1, C2a(ii), D & \\
\hline Arabian Bustard & Ardeotis arabs & Gruiformes & CR & $\begin{array}{l}\text { A2,A3,A4abd; C2aii. Perhaps } \\
\text { also D and C2ai and C1? }\end{array}$ & \\
\hline Houbara Bustard & Chlamydotis undulata & Gruiformes & $\mathrm{CR}$ & A2,A3,A4abd. probably C1 & \\
\hline Brown Fish-owl & Ketupa zeylonensis & Strigiformes & CR & & \\
\hline Black Francolin & Francolinus francolinus & Galliformes & EN & A2bd & \\
\hline White-headed Duck & Oxyura leucocephala & Anseriformes & EN & $\mathrm{D}$ & \\
\hline African Sacred Ibis & Threskiornis aethiopicus & Ciconiiformes & EN & $\mathrm{D}$ & \\
\hline Yellow Bittern & Ixobrychus sinensis & Ciconiiformes & EN & & \\
\hline Goliath Heron & Ardea goliath & Ciconiiformes & EN & $\mathrm{D}$ & \\
\hline Sooty Falcon & Falco concolor & Falconiformes & $\mathrm{EN}$ & D1 & \\
\hline Peregrine Falcon & Falco peregrinus & Falconiformes & EN & D1 & \\
\hline Griffon Vulture & Gyps fulvus & Falconiformes & $\mathrm{EN}$ & $\mathrm{A} 2 \mathrm{ae}$ & \\
\hline Tawny Eagle & Aquila rapax & Falconiformes & EN & C2a(ii) & \\
\hline Golden Eagle & Aquila chrysaetos & Falconiformes & $\mathrm{EN}$ & $\mathrm{C} 2 \mathrm{a}(\mathrm{i})$ & \\
\hline Verreaux's Eagle & Aquila verreauxii & Falconiformes & EN & $\mathrm{D}$ & \\
\hline Sooty Tern & Sterna fuscata & Charadriiformes & EN & $\mathrm{D}$ & \\
\hline Black-bellied Sandgrouse & Pterocles orientalis & Pterocliformes & EN & $\mathrm{C} 2 \mathrm{a}(\mathrm{ii})$ & \\
\hline African Olive-pigeon & Columba arquatrix & Columbiformes & EN & $\mathrm{D}$ & \\
\hline Collared Kingfisher & Todiramphus chloris & Coraciiformes & EN & $\mathrm{A} 2 \mathrm{c}+3 \mathrm{c}+4 \mathrm{c} ; \mathrm{B} 2 \mathrm{abi}, \mathrm{ii}, \mathrm{iii}, \mathrm{iv}, \mathrm{v}$ & \\
\hline Basra Reed-warbler & Acrocephalus griseldis & Passeriformes & EN & B2ab(i,ii,iii,iv,v) & YES \\
\hline Sykes's Warbler & Hippolais rama & Passeriformes & EN & $\mathrm{D}$ & \\
\hline Oriental White-eye & Zosterops palpebrosus & Passeriformes & EN & $\mathrm{D}$ & \\
\hline Red-rumped Wheatear & Oenanthe moesta & Passeriformes & EN & D1 & \\
\hline Syrian Serin & Serinus syriacus & Passeriformes & EN & $\mathrm{A} 2 \mathrm{acd}+\mathrm{A} 3 \mathrm{~cd}+\mathrm{A} 4 \mathrm{acd}$ & YES \\
\hline European Goldfinch & Carduelis carduelis & Passeriformes & EN & $\mathrm{A} 2 \mathrm{bd}+3 \mathrm{~d}+4 \mathrm{bd}$ & \\
\hline Helmeted Guineafowl & Numida meleagris & Galliformes & VU & $\mathrm{A} 2 \mathrm{~b}, \mathrm{~d}(+3 \mathrm{~b}, \mathrm{~d}+4 \mathrm{~b}, \mathrm{~d} ?)$ & \\
\hline Hamerkop & Scopus umbretta & Ciconiiformes & VU & $\mathrm{C} 2 \mathrm{a}(\mathrm{ii})$ & \\
\hline Pink-backed Pelican & Pelecanus rufescens & Pelecaniformes & VU & C2a(ii) & \\
\hline Pygmy Cormorant & Phalacrocorax pygmeus & Pelecaniformes & $\mathrm{VU}$ & $\mathrm{C} 1$ & \\
\hline Socotra Cormorant & Phalacrocorax nigrogularis & Pelecaniformes & VU & $\mathrm{A} 2 \mathrm{acd}+\mathrm{A} 3 \mathrm{~cd}+\mathrm{A} 4 \mathrm{acd}$ & YES \\
\hline Barbary Falcon & Falco pelegrinoides & Falconiformes & VU & A2ad & \\
\hline Black-winged Kite & Elanus caeruleus & Falconiformes & VU & D1 & \\
\hline Lammergeier & Gypaetus barbatus & Falconiformes & $\mathrm{VU}$ & D1 & \\
\hline Egyptian Vulture & Neophron percnopterus & Falconiformes & VU & A2ae & \\
\hline Lappet-faced Vulture & Torgos tracheliotos & Falconiformes & VU & D1 & \\
\hline Short-toed Snake-eagle & Circaetus gallicus & Falconiformes & VU & D1 & \\
\hline Socotra Buzzard & Buteo socotraensis & Falconiformes & VU & D1 & YES \\
\hline Crab Plover & Dromas ardeola & Charadriiformes & VU & $\mathrm{C} 1$ & $>70 \% \mathrm{GR}$ \\
\hline Roseate Tern & Sterna dougallii & Charadriiformes & VU & D1 & \\
\hline Arabian Woodpecker & Dendrocopos dorae & Piciformes & $\mathrm{VU}$ & $\mathrm{A} 2 \mathrm{ac}+3 \mathrm{c}+4 \mathrm{ac}$ & YES \\
\hline Middle Spotted Woodpecker & Dendrocopos medius & Piciformes & $\mathrm{VU}$ & $\mathrm{C} 2 \mathrm{a}(\mathrm{i})$ & \\
\hline White-throated Dipper & Cinclus cinclus & Passeriformes & VU & D1 & \\
\hline Abd Al Kuri Sparrow & Passer hemileucus & Passeriformes & $\mathrm{VU}$ & D1 & YES \\
\hline Richard's Pipit & Anthus richardi & Passeriformes & VU & D1 & \\
\hline
\end{tabular}


Table 4. Threatened and Near Threatened breeding birds in the assessment region continued.

\begin{tabular}{|c|c|c|c|c|c|}
\hline Common Name & Scientific Name & Order & $\begin{array}{c}\text { Regional } \\
\text { Status }\end{array}$ & Criteria & Endemic \\
\hline Fire-fronted Serin & Serinus pusillus & Passeriformes & VU & D1 & \\
\hline Asian Crimson-winged Finch & Rhodopechys sanguineus & Passeriformes & VU & D1 & \\
\hline Marbled Duck & Marmaronetta angustirostris & Anseriformes & NT & C2aii & \\
\hline Red-crested Pochard & Netta rufina & Anseriformes & NT & $\mathrm{D} 1, \mathrm{C} 2 \mathrm{a}(\mathrm{i})$ & \\
\hline Ferruginous Duck & Aythya nyroca & Anseriformes & NT & $\mathrm{C} 2 \mathrm{a}(\mathrm{i})$ & \\
\hline Jouanin’s Petrel & Bulweria fallax & Procellariiformes & NT & $\mathrm{D} 2$ & YES \\
\hline Abdim's Stork & Ciconia abdimii & Ciconiiformes & NT & D1 & \\
\hline White Stork & Ciconia ciconia & Ciconiiformes & NT & D1 & \\
\hline Grey Heron & Ardea cinerea & Ciconiiformes & NT & D1 & \\
\hline Purple Heron & Ardea purpurea & Ciconiiformes & NT & D1 & \\
\hline Masked Booby & Sula dactylatra & Pelecaniformes & NT & $\mathrm{D} 2$ & \\
\hline Lesser Kestrel & Falco naumanni & Falconiformes & NT & D1 & \\
\hline Western Marsh-harrier & Circus aeruginosus & Falconiformes & NT & D1 & \\
\hline Water Rail & Rallus aquaticus & Charadriiformes & NT & D1 & \\
\hline Pied Avocet & Recurvirostra avosetta & Charadriiformes & NT & D1 & \\
\hline Greater Sand Plover & Charadrius leschenaultii & Charadriiformes & NT & D1 & \\
\hline Great Spotted Cuckoo & Clamator glandarius & Cuculiformes & NT & D1 & \\
\hline Common Cuckoo & Cuculus canorus & Cuculiformes & NT & D1 & \\
\hline Klaas's Cuckoo & Chrysococcyx klaas & Cuculiformes & NT & D1 & \\
\hline European Roller & Coracias garrulus & Coraciiformes & NT & D1 & \\
\hline Common Kingfisher & Alcedo atthis & Coraciiformes & NT & D1 & \\
\hline Horned Lark & Eremophila alpestris & Passeriformes & NT & D1 & \\
\hline Island Cisticola & Cisticola haesitatus & Passeriformes & NT & C2a(ii) & YES \\
\hline Moustached Warbler & Acrocephalus melanopogon & Passeriformes & NT & D1 & \\
\hline Yemen Warbler & Sylvia buryi & Passeriformes & NT & $A 2 c+3 c+4 c$ & YES \\
\hline Black Redstart & Phoenicurus ochruros & Passeriformes & NT & D1 & \\
\hline Common Redstart & Phoenicurus phoenicurus & Passeriformes & NT & D1 & \\
\hline Rufous-tailed Rock-thrush & Monticola saxatilis & Passeriformes & NT & D1 & \\
\hline Yemen Accentor & Prunella fagani & Passeriformes & NT & C2a(ii) & YES \\
\hline Grey Wagtail & Motacilla cinerea & Passeriformes & NT & D1 & \\
\hline Arabian Grosbeak & Rhynchostruthus percivali & Passeriformes & NT & C2a(ii) & YES \\
\hline Ortolan Bunting & Emberiza hortulana & Passeriformes & NT & D1 & \\
\hline Socotra Bunting & Emberiza socotrana & Passeriformes & NT & $\mathrm{B} 1+2 \mathrm{ab}$ & YES \\
\hline
\end{tabular}




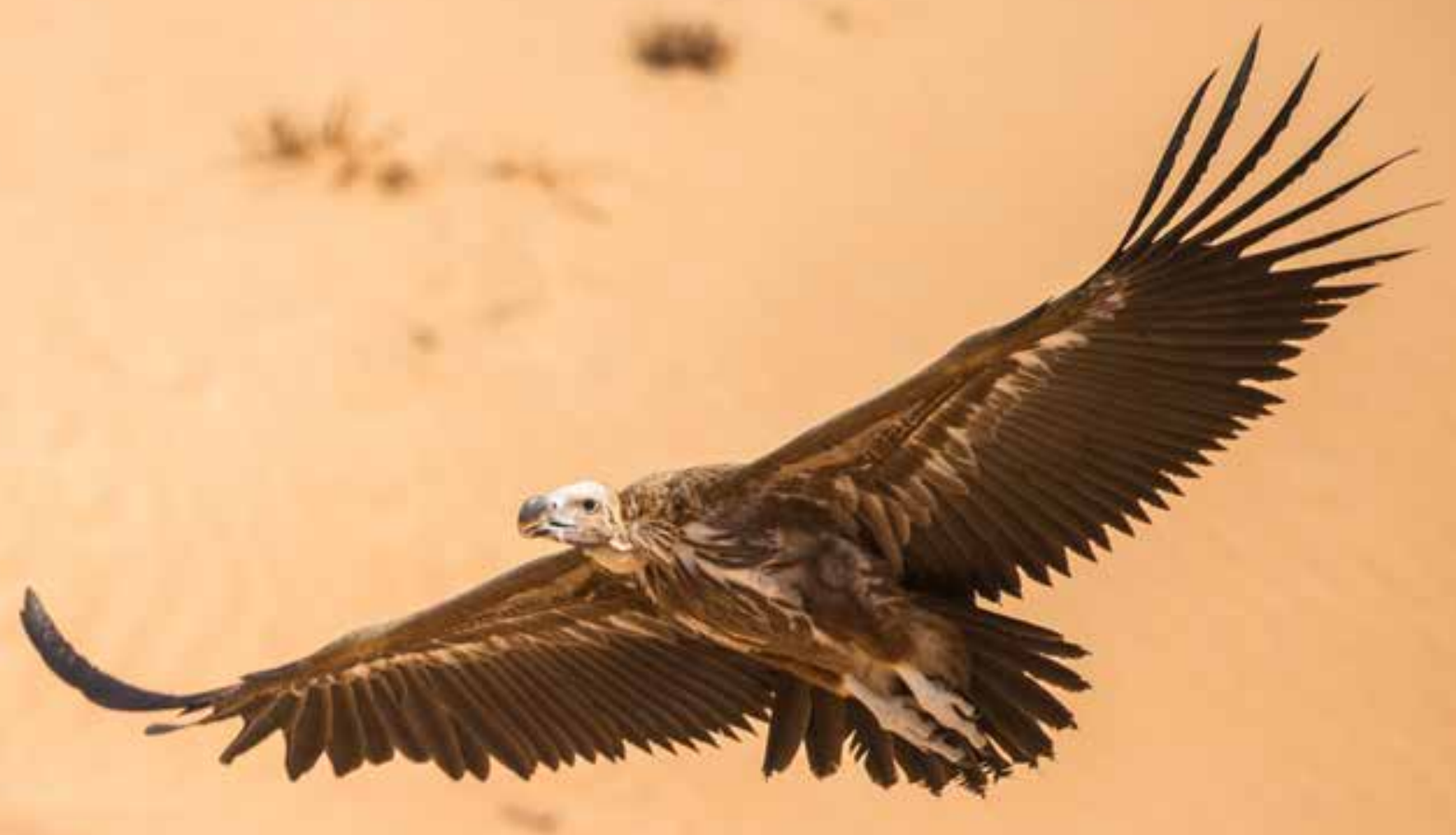

While there is no evidence of vulnerability to Diclofenc in the region there is real concern for vultures in Arabia due to declining populations; with both the Lappet-faced Vulture Torgos tracheliotos (above) and the Egyptian Vulture Neophron percnopterus (below) assessed as Vulnerable. Both photographs $\odot$ Ahmed Al Ali.

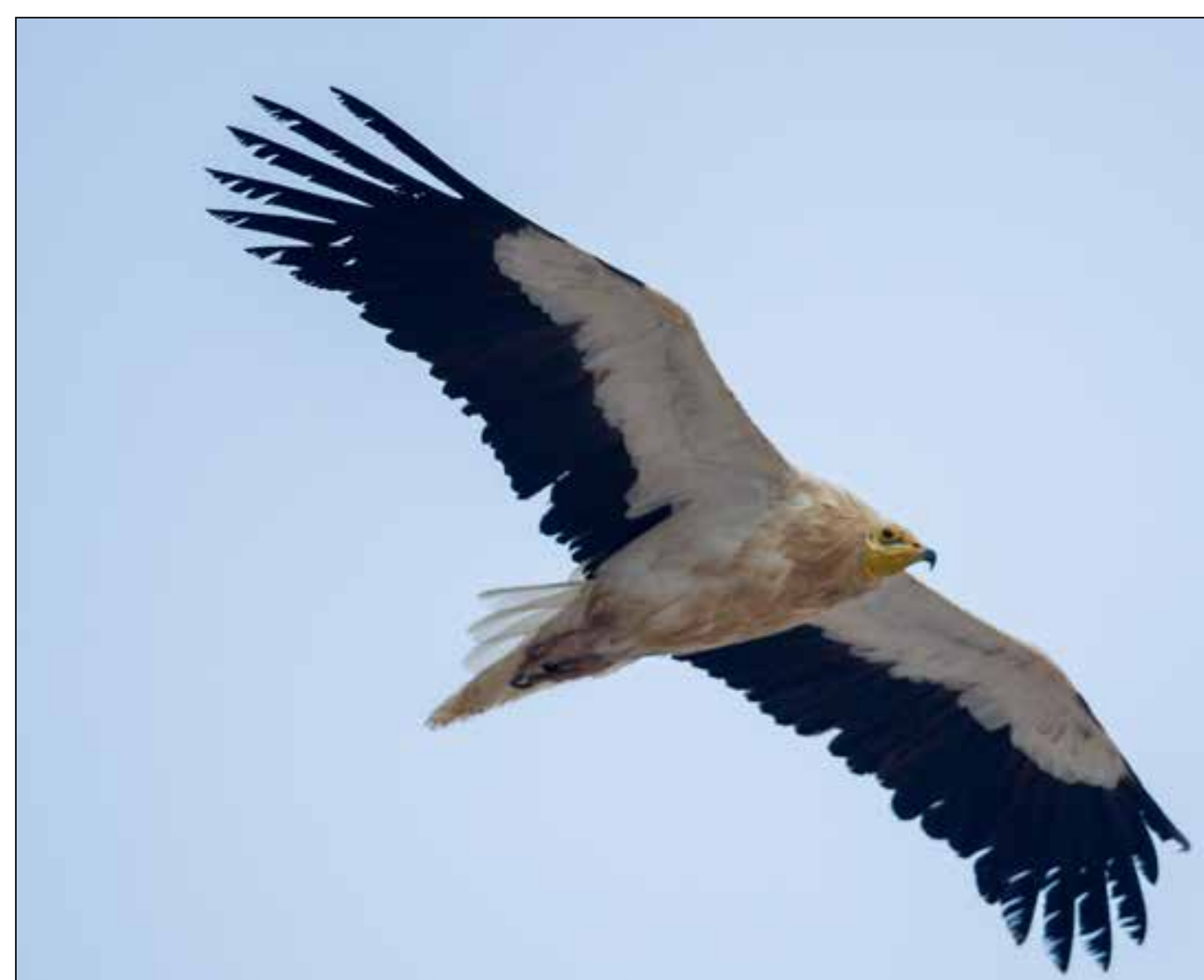


Table 5. Regional Red List status by taxonomic order

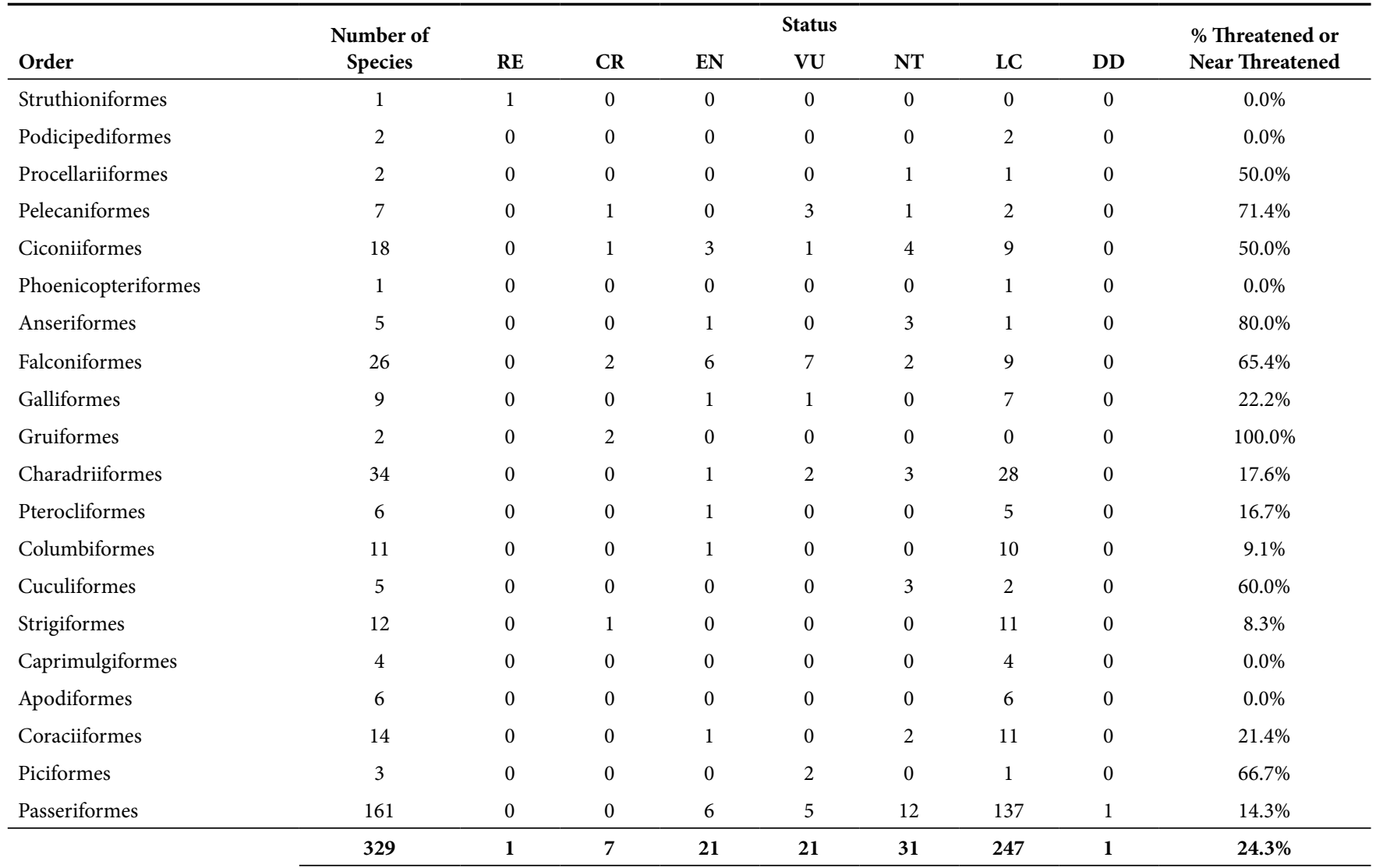

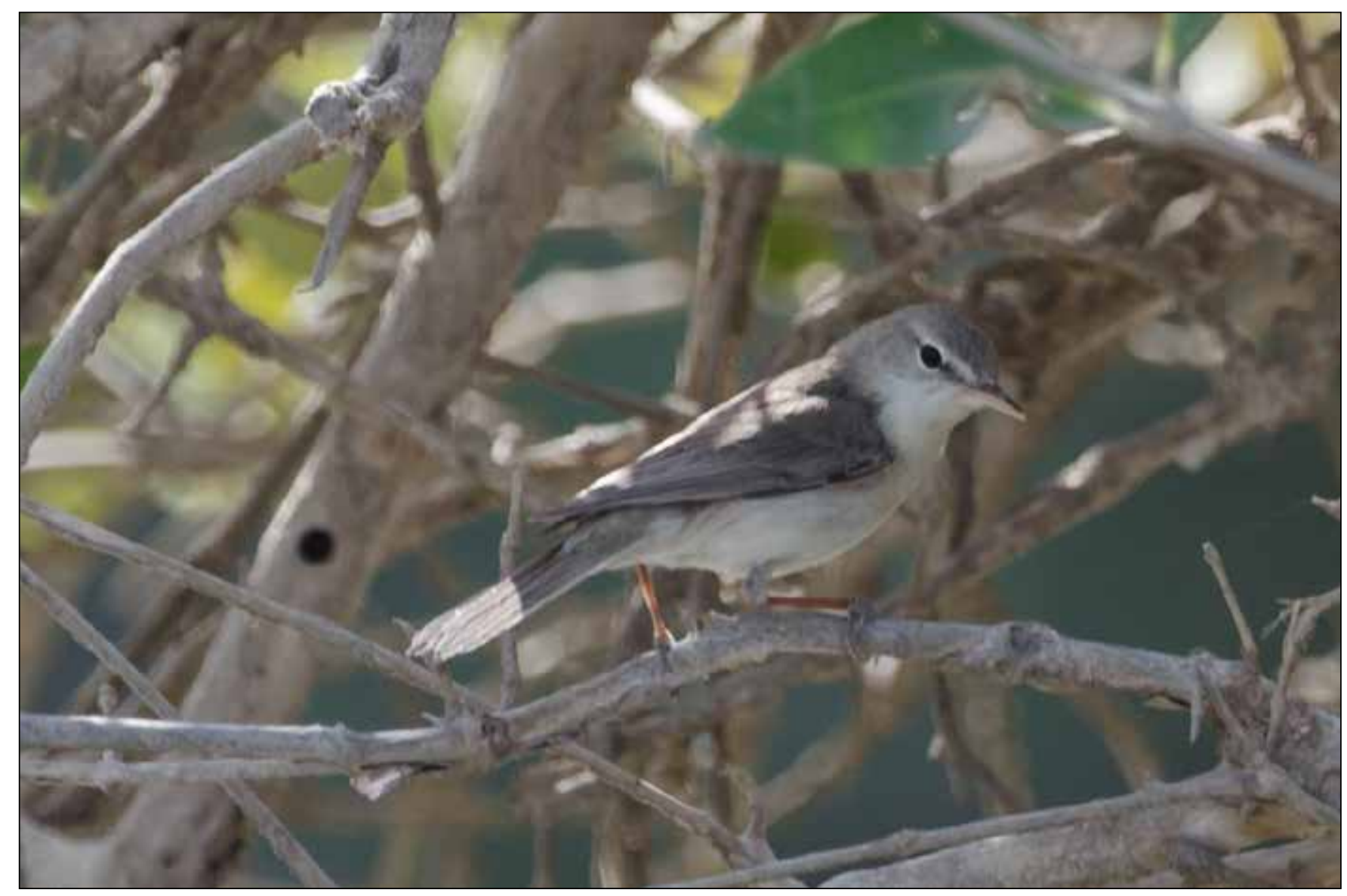

Sykes's Warbler Iduna rama is widely distributed in western and central Asia, but in Arabia is only known to breed in the mangroves in Khor Kalba; on the east coast of the UAE. @ Ahmed Al Ali. 


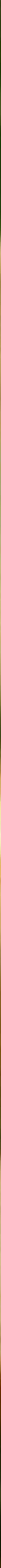




\section{Conclusions}

\subsection{Conservation priorities}

The regional assessment of breeding birds benefited greatly from the amount of recent attention given to the birds of this region and in particular the ABBA project, so ably coordinated by Mike Jennings. This assessment has revealed that around $25 \%$ of breeding birds in the Arabian Peninsula are threatened (Critically Endangered, Endangered, Vulnerable) or Near Threatened, according to the IUCN Categories and Criteria. Of the remainder, 247 species are assessed as Least Concern and one as Data Deficient. Figures 3 and 4 provide an overview of the areas of species richness for endemic species and threatened species, respectively.
The Socotra archipelago harbours 10 endemic breeding birds. Of these 10 species, two are categorized as Vulnerable and two as Near Threatened, with the remaining six species Least Concern. Thus the endemic avifauna is not highly threatened, overall, at present. However, these islands remain of exceptional conservation importance for birds and many other endemic species (e.g. reptiles - see Cox et al. 2012) and they require special conservation attention in order to safeguard this unique fauna in the medium to long-term.

A second area of very high significance for endemic breeding birds is a relatively narrow band in the highlands of the southwest of the region, running through Asir in Saudi Arabia and western Yemen. Eight endemic breeding birds occur here,

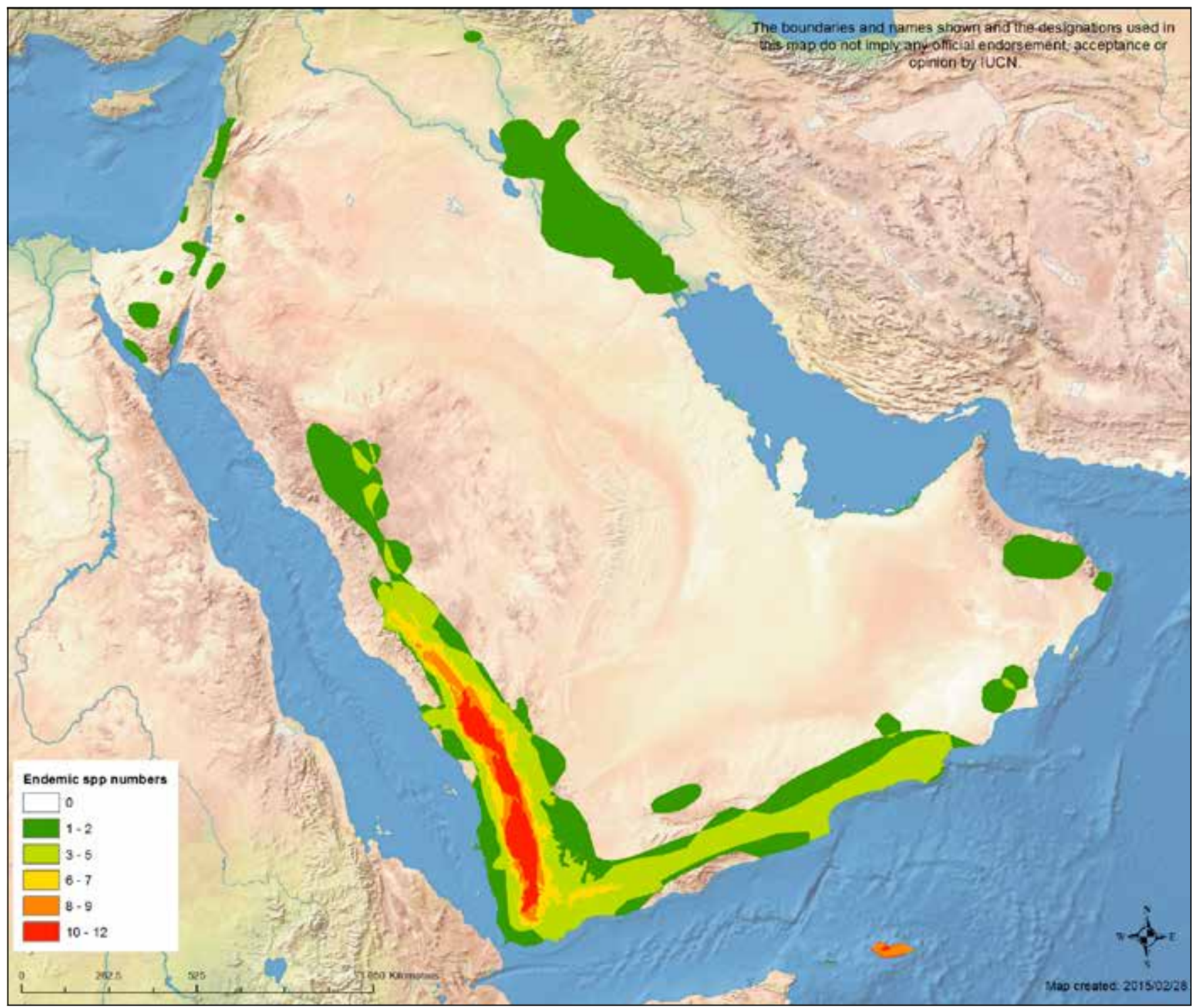

Figure 3. Species richness of endemic breeding birds of Arabia. 
one is Vulnerable, three are Near Threatened and four Least Concern. Therefore, as with Socotra, levels of threat to the endemic species may not appear particularly high at this time, but these mountains also harbour non-endemic breeding species that are threatened and have wide importance for biodiversity conservation. It is therefore essential to conduct systematic monitoring of species' status and threats, such as shortage of water and consequent effects on vegetation, climate change, and tree cutting. The Tigris and Euphrates valleys also hold many threatened species, especially in the Iraq marshes, which represent a unique ecosystem and are an internationally important site for biodiversity conservation.

\subsection{Application of project outputs}

The outputs of this assessment can be used to inform conservation measures for individual species and suites of species. They can also be applied at the regional scale to assist governments and organizations, such as IUCN, to identify important sites for conservation, including Key Biodiversity Areas, at national or regional scales.

\subsection{Future work}

If the information on the breeding birds of the Arabian Peninsula is to be effectively integrated within the development or environmental planning process then:

- The data collated will need to be maintained and updated regularly through on-going collaboration with the network of experts who have contributed their valuable time to this project, and others;

- Links between IUCN and its partners and decision and policy makers and regional decision makers and policy makers must be maintained and strengthened and the

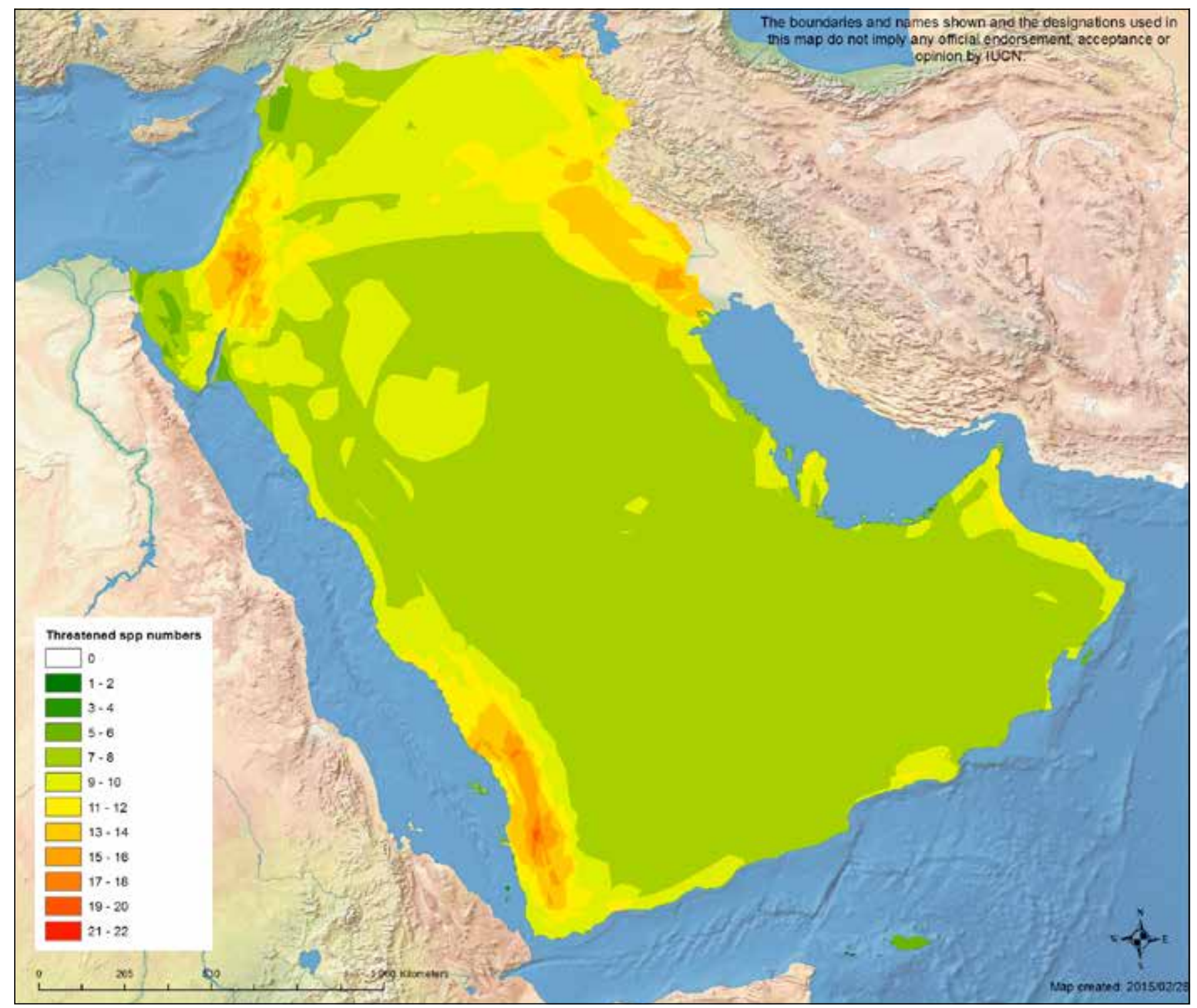

Figure 4. Species richness of threatened breeding birds of Arabia. 
data must be made freely available to these people and/ or organizations; and

- A "best practice" methodology for the process of integrating biodiversity information within the environmental/development planning process needs to be developed. It is important that this methodology aims to provide the information in a "user-friendly" format for all stakeholders and provides guidelines as to when and where the information should appropriately be made available.

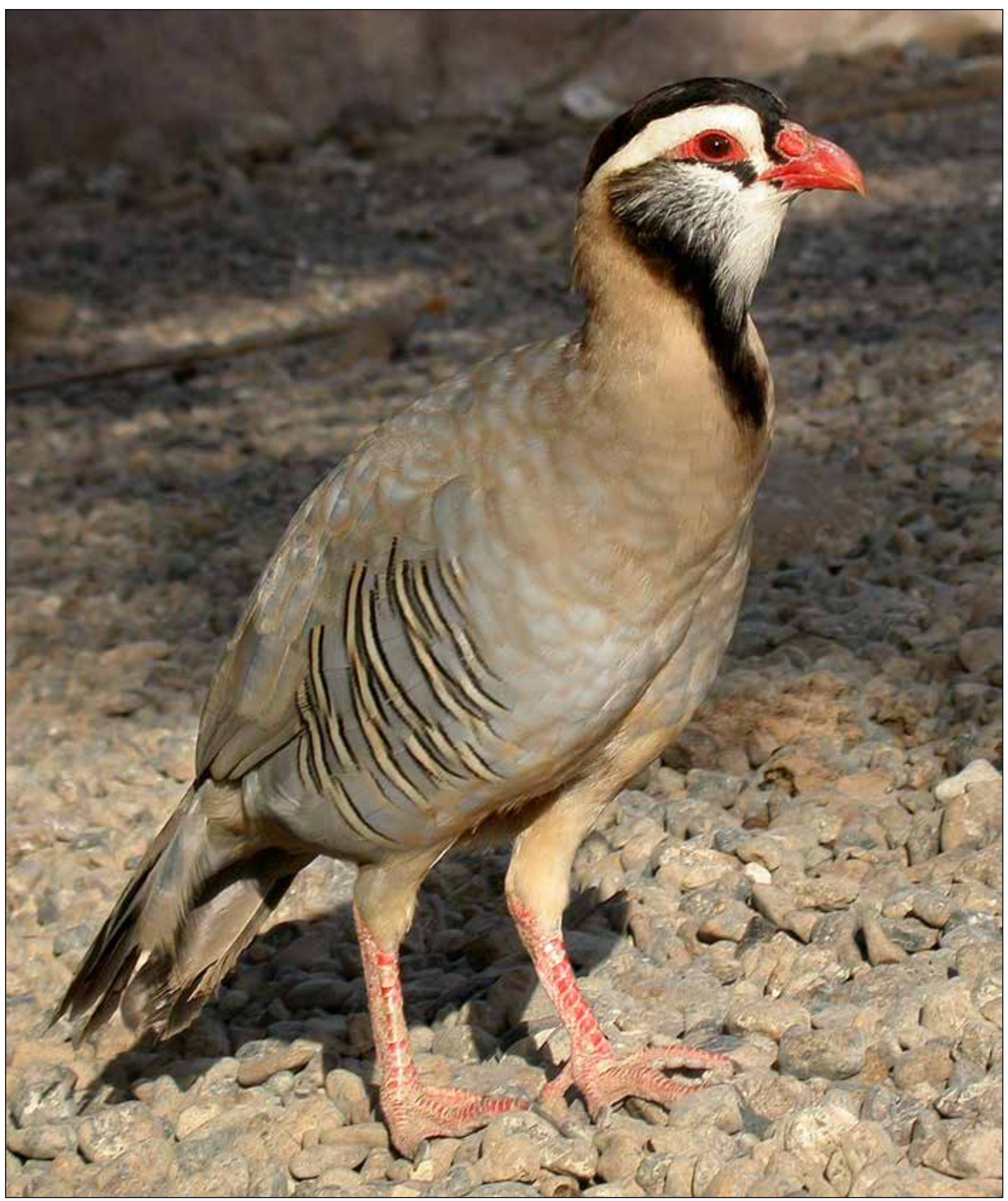

The Arabian Partridge Alectoris melanocephala is endemic to southwestern Arabia and southern Oman. Classified as Least Concen as population is increasing. (C) Jane and Kevin Budd. 


\section{References and further reading}

Andrews, I.J. (1995) The birds of the Hashemite Kingdom of Jordan. Musselburgh, Scotland, UK: I.J. Andrews.

BirdLife International (2013) Species factsheet: Hypocolius ampelinus. Downloaded from http:www.birdlife.doc.org on 01 July 2013.

Cox, N.A., Mallon, D., Bowles, P., Els, J. \& Tognelli, M.F. (Compilers) (2012) The conservation status and distribution of reptiles of the Arabian Peninsula. Cambridge, UK and Gland Switzerland: IUCN, and Sharjah, UAE: Environment and Protected Areas Authority.

Eriksen, J., Sargeant, D.E. and Victor, R. (2003) Oman Bird List. Edition 6. Muscat, Oman: Centre for Environmental Studies and Research, Sultan Qaboos University.

Gallagher, M.D. and Woodcock, M.W. (1980). The Birds of Oman. London, UK: Quartet Books.

IUCN (2001) IUCN Red List Categories and Criteria. Version 3.1. Gland, Switzerland \& Cambridge, UK: IUCN.

IUCN (2003) Guidelines for Application of IUCN Criteria at Regional Level. Gland, Switzerland \& Cambridge, UK: IUCN.

Jennings, M.C. (2010) Atlas of the breeding birds of Arabia. Fauna of Arabia 25.

Mallon, D. \& Budd, K. (Compilers) (2011) Regional Red List Status of Carnivores in the Arabian Peninsula. Cambridge, UK and Gland Switzerland: IUCN, and Sharjah, UAE: Environment and Protected Areas Authority.

Mittermeier, R.A. et al. Editors. (2004) Hotspots Revisited. Washington DC: Cemex/Conservation International.

Murdoch, D.A. \& Betton, K.F. (2008) A checklist of the birds of Syria. Sandgrouse Supplement 2: 1-48.

Perlman, Y. \& Meyrav, J., compilers (2009) Checklist of the birds of Israel. Tel-Aviv: Israel Ornithological Center, Society for the Protection of Nature in Israel.

Pons, J-M, Kirwan, G., Porter, R. \& Fuchs, J. (2013) A reappraisal of the systematic affinities of Socotran, Arabian and East African scops-owls (Otus, Strigidae) using a combination of molecular, biometric and acoustic data. Ibis 155: 518-533.
Porter, R.F. (2014) The mystery of the 'Syrian' Serins wintering in northern Iraq is solved. Sandgrouse 36: 58-60.

Porter, R. \& Aspinall, S. (2010) Birds of the Middle East. Second edition. London: Christopher Helm. Helm Field Guides.

Porter, R.F. \& Suleiman, A.S. (2012) The Egyptian vulture Neophron percnopterus on Socotra, Yemen: population, ecology, conservation and ethno-ornithology. Sandgrouse 34: 44-62.

Porter, R.F. \& Suleiman, A.S. (2013) The populations and distribution of the breeding birds of the Socotra archipelago, Yemen: 1. Sandgrouse to buntings. Sandgrouse 35: 43-81.

Porter, R.F. \& Suleiman, A.S. (2014). The populations and distribution of the breeding birds of the Socotra archipelago, Yemen: 2. Shearwaters to terns. Sandgrouse 36: 8-33.

Porter, R., Samraoui, B., Livet, D., Mallon, D. and Budd, K. (2009) Proceedings of the 10th Conservation Workshop for the Fauna of Arabia: Shorebirds of the Arabian Peninsula. Sharjah, UAE: Environment and Protected Areas Authority.

RSCN (2013). The state of Jordan's birds report. Amman, Jordan: Royal Society for the Conservation of Nature.

Robb, M.S., van den Bergh, A.B. \& Constantine, M. (2013) A new species of Strix owl from Oman. Dutch Birding 35: 275-310.

Robb, M. S., Sangster, G., Aliabadian, M., van den Berg, A. B., Constantine, M., Irestedt, M., Khani, A., Babak, S.M., Nunes, J.M.G., Willson, M.S. \& Walsh, A. J. (2015) The rediscovery of Strix butleri (Hume, 1878) in Oman and Iran, with molecular resolution of the identity of Strix omanensis Robb, van den Berg and Constantine, 2013. bioRxiv. Available at: http://biorxiv.org/content/ early/2015/08/20/025122.full.pdf.

Salim, M.A., Al Sheikhly, O.F., Majeed, K.A. \& Porter, R.F. (2012) An annotated checklist of the birds of Iraq. Sandgrouse 34: 4-43.

Suleiman, A.S. \& Taleb, N. (2010) Eradication of the House Crow Corvus splendens on Socotra, Yemen. Sandgrouse 32: 136-140.

Vere Benson, S. (1970) Birds of Lebanon and the Jordan Area. London: International Council for Bird Preservation \& Frederick Warne \& Co Ltd. 


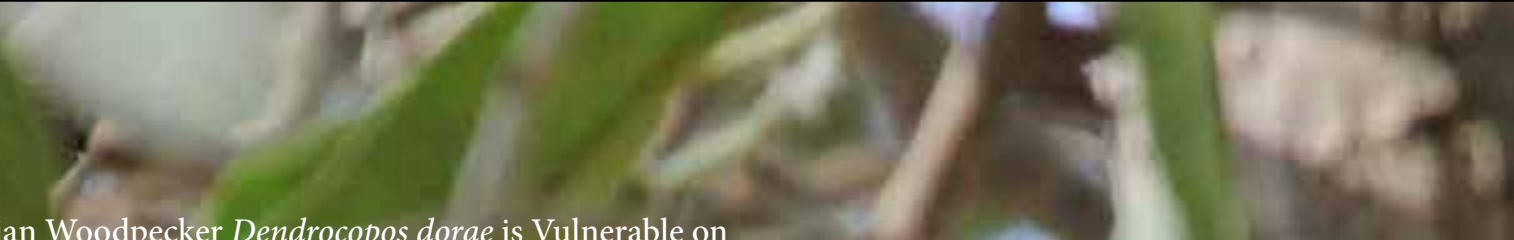

The Arabian Woodpecker Dendrocopos dorae is Vulnerable on the Arabian Peninsula and in decline due to habitat loss and degradation. (๑) Richard Porter

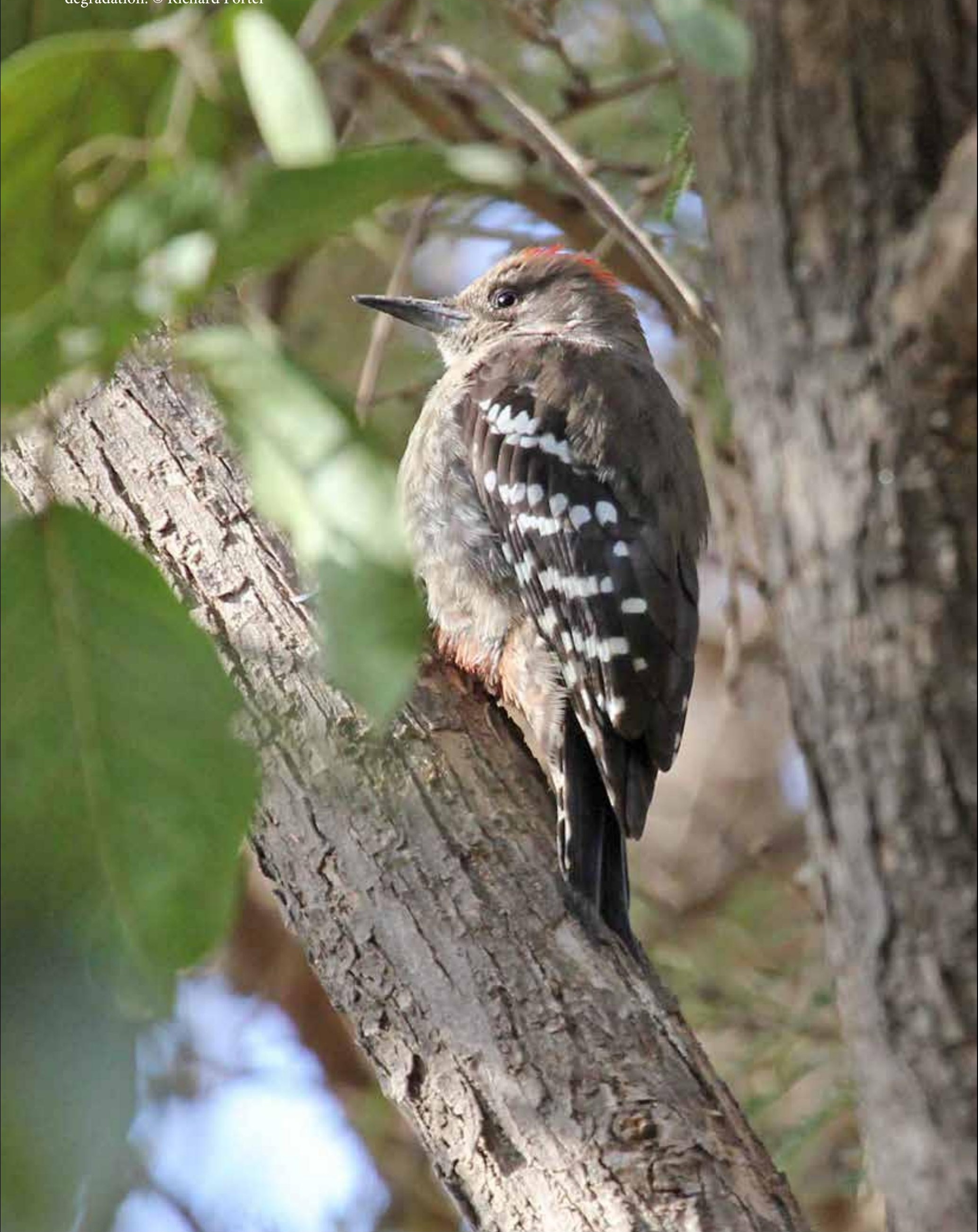




\section{Appendix 1. Participants List}

\begin{tabular}{|c|c|}
\hline Algeria & Boudjema Samraoui \\
\hline Bahrain & Adel Mohammed Al Awadhi \\
\hline Iraq & Mudhafar Salim \\
\hline Jordan & Sharif al Jbour \\
\hline Jordan & Laith el-Moghrabi \\
\hline Kuwait & Salah Behbehani \\
\hline Kuwait & Mike Pope \\
\hline Oman & Khalid Al Rasbi \\
\hline Oman & Husam Al-Asfoor \\
\hline Oman & Mahmood Alabri \\
\hline Oman & Waheed Abdullah Al Fazari \\
\hline Qatar & Cromwell Purchase \\
\hline Saudi Arabia & Abdullah As Suhaibani \\
\hline Saudi Arabia & Mohammed Shobrak \\
\hline Saudi Arabia & Monif Al Rashidi \\
\hline Syria & Nabegh Asswad \\
\hline UAE & Reza Khan \\
\hline UAE & Jeruel Cabadonga Aguhob \\
\hline UAE & Hassan Zain AlSharif \\
\hline UAE & Ahmed Al Ali \\
\hline UAE & Shahid Bashir Khan \\
\hline UAE & Maher Kabshawi \\
\hline UAE & Dr. Pathan \\
\hline UAE & Richard Hornby \\
\hline UAE & Nick P. Williams \\
\hline UK & Mike Jennings \\
\hline UK & Joe Taylor \\
\hline UK & Andy Symes \\
\hline $\mathrm{UK}$ & Richard Porter \\
\hline UK & David Mallon \\
\hline Yemen & Masaa Mahdi Al Jumaily \\
\hline Yemen & Omar Al-Saghier \\
\hline
\end{tabular}

University of Guelma

Directorate of Protected Areas

Nature Iraq

BirdLife International

IUCN-ROWA

The Scientific Centre, Kuwait

Kuwait Ornithological Records Committee

Omani Wild Animals Breeding Centre

Royal Court Affairs

Royal Court Affairs

Office for Conservation of the Environment, Diwan of the Royal Court

Al Wabra Wildlife Preservation

Environmental Balance Est.

Taif University

University of Hail

Syrian Society for the Conservation of Wildlife

Dubai Municipality

Dubai Municipality

Dubai Municipality

Environment \& Protected Areas Authority

Environment Agency - Abu Dhabi

Environment Agency - Abu Dhabi

Management of Nature Conservation

Nautica Environmental Associates

UNEP/CMS Office - Abu Dhabi

Atlas of the Breeding Birds of Arabia

BirdLife International

BirdLife International

BirdLife International

Manchester Metropolitan University

Sana’a University

UNDP Global Environmental Facility, Small Grants Program 


\section{Appendix 2. Regional Red List assessments of the breeding birds of the Arabian Region}

Reg cat = Regional Red List category; Reg adj = regional adjustment to category due to potential rescue effect (IUCN 2003); Criteria = RL criteria (IUCN 2001); In Notes/Justification column, 'ABBA' = Atlas of the Breeding Birds of Arabia (Jennings 2010).

\begin{tabular}{|c|c|c|c|c|c|}
\hline Common Name & Scientific Name & Reg Cat & Reg adj & Criteria & Regional trend \\
\hline Ostrich & Struthio camelus & RE & & & \\
\hline
\end{tabular}

The form S. c. syriacus was formerly quite widely distributed in the region but became extinct during the 20th century (del Hoyo et al. 1992, Jennings 1996). In Jordan last records date from 1920s-1930s, with unconfirmed reports in 1941 and 1966 (Andrews 1995). The NE African form S.c. camelus has been reintroduced into Mahazat as-Sayd Reserve in Saudi Arabia (125-150 birds).
Helmeted Guineafowl
Numida meleagris
$\mathrm{VU}$
A2b,d (+3b,d+4b,d?)
Declining

2,000 pairs (ABBA) but declining due to hunting, egg collecting for food and rearing and habitat degradation. Hunting pressure is exacerbated by movements of soldiers in connection with conflicts in some areas. Anecdotal evidence indicates severe declines in Saudi Arabia; not as many seen in Yemen as formerly; the price for live birds is increasing (currently 4 times that for Philby's Partridge). Decline estimated at $>30 \%$ (but less than $50 \%$ ) over the 12-year trend period (3 generations). VU A2abd +A3abd; C1. Little or no rescue effect. Some morphological differences noted compared to African populations but not formally named as a subspecies.

Chukar Alectoris chukar $\quad$ LC $\quad$ Declining

6,000 pairs (ABBA) plus birds in north; considered to be declining in Iraq, Syria and Jordan, but not enough for NT.
Philby's Partridge
Alectoris philbyi
LC
Declining

ENDEMIC. 50,000 mature individuals in Arabian Peninsula (ABBA); stable in Yemen; declining in Saudi Arabia owing to hunting and changes in agriculture; can be seen around tourist complexes in Saudi Arabia and near edge of Sana’a city; still plenty of agricultural areas in Yemen; considered a bit of a pest, and thus persecuted.
Arabian Partridge
Alectoris melanocephala
LC
Increasing

ENDEMIC. 400,000 pairs (ABBA). Native in SW Arabia and S Oman, possibly introduced into northern Oman and UAE. Captive bred birds released into areas for hunting; probably increasing.
See-see Partridge
Ammoperdix griseogularis
LC
Stable?

Widespread and numerous in the north. Hunting pressure may be low, as numbers are not decreasing in e.g. lowland Syria.
Sand Partridge
Ammoperdix heyi
LC
Declining

Near Endemic. 900,000 pairs in Arabian Peninsula (ABBA). Declining outside PAs in Jordan; very susceptible to hunting as it lives at lower elevations compared to other partridges. Decline estimated at $<20 \%$ so has not reached threshold for NT under criterion A.
Black Francolin
Francolinus francolinus
EN
A2bd
Declining

Big decline throughout regional range (Iraq, Jordan, Syria) due to hunting and destruction of riparian habitats. Decline estimated at least $50 \%$ in trend period of 12 years. No rescue effect as adjacent populations are also under pressure. Evidence: decline in observations, hunters' reports. Observed reduction in extent of riparian habitats/thickets.

Grey Francolin $\quad$ Francolinus pondicerianus $\quad$ LC

LC Increasing

Probably introduced before 1880 and now up to 70,000 pairs and increasing (ABBA). LC if native, NA if not.
Common Quail
Coturnix coturnix
LC
Stable (or Increasing)

6,000 pairs in Saudi Arabia, c.1,000 pairs in Iraq. Widely bred in captivity and probably increasing as a result. The area of irrigated fields is increasing. Trapped in nets in large numbers during migration. Impacted by powerlines.
Ruddy Shelduck
Tadorna ferruginea
LC
Stable

1000 pairs in Iraq and Syria.

Marbled Duck Marmaronetta angustirostris NT y C2aii Declining

Formerly bred in N Jordan. 3,500-4,500 pairs in Iraq plus c.100 in Syria, so c.8,000 mature individuals in region. Projected continuing decline based on known threats: Dams on Tigris and Euphrates, draining of wetlands. Some hunting - one of three most abundant duck species on Iraqi Marshes in summer. Probably a single subpopulation based on known tendency for movements. VU C2a(ii) with regional adjustment NT. 


\begin{tabular}{llcclc}
\hline Common Name & Scientific Name & Reg Cat & Reg adj & Criteria & Regional trend \\
\hline Red-crested Pochard & Netta rufina & NT & y & D1, C2a(i)
\end{tabular}

One confirmed breeding record in Syria, 2004-09; $<500$ pairs in Iraq, so total mature individuals $<1,000$. VU D1 -> NT. Also VU C2a(i), With rescue effect - NT. Drainage and reduced flows due to dams are bigger threats than hunting .

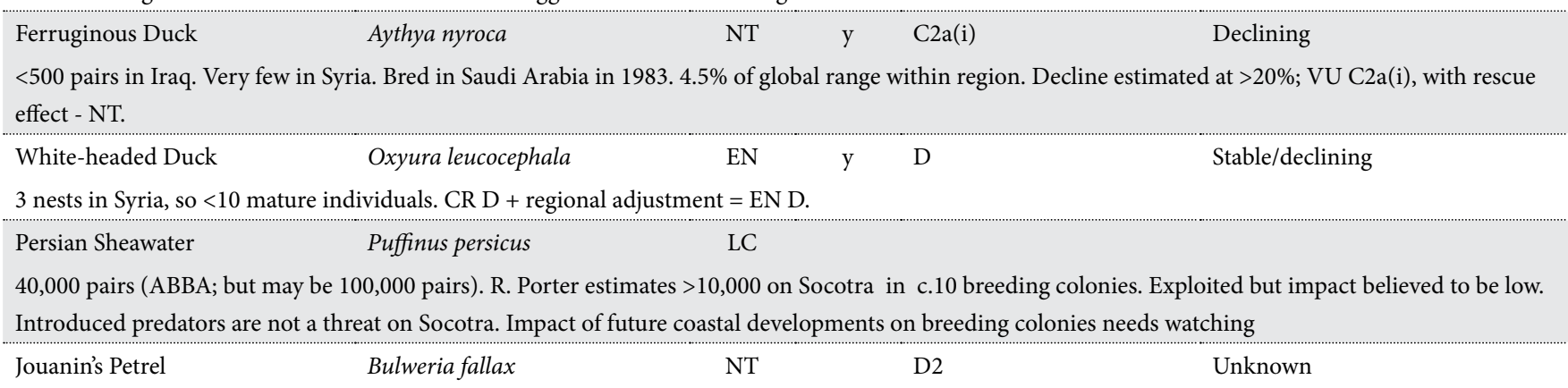

BREEDING ENDEMIC TO SOCOTRA. 3,000 pairs (ABBA); 'at-sea' threats unknown. Colonies vulnerable to introduced predators (rats, cats) and development. NT D2.
Little Grebe
Tachybaptus ruficollis
LC Increasing

Opportunistic breeder. Increasing in Syria and Jordan. 1,700 pairs (ABBA), plus 2,000 pairs in Iraq; more in Syria and Jordan.

Great Crested Grebe $\quad$ Podiceps cristatus $\quad$ LC $\quad$ y $\quad$ Stable/increasing

$<1,200$ mature individuals in region including $<100$ pairs in Iraq; NT (close to VU D1) + Regional adjustment = LC
Greater Flamingo
Phoenicopterus roseus
LC

200-2,000 pairs in Arabian Peninsula (ABBA). 4,000 pairs in Syria in 2009; nil in 2008. c. 6,000 in Oman. Large annual fluctuations in breeding. Many summer around region. Perhaps $>10,000$ mature individuals in region.
Abdim's Stork
Ciconia abdimii
NT $\quad \mathrm{y} \quad \mathrm{D} 1$
Declining

Only 4 in Saudi Arabia; c.600 in Yemen + non-breeders; <1000 = VU D1. + Rescue = NT. Big decline in recent years; this might warrant a higher category under $\mathrm{C} 1 \mathrm{EN}$, then regional adjustment.

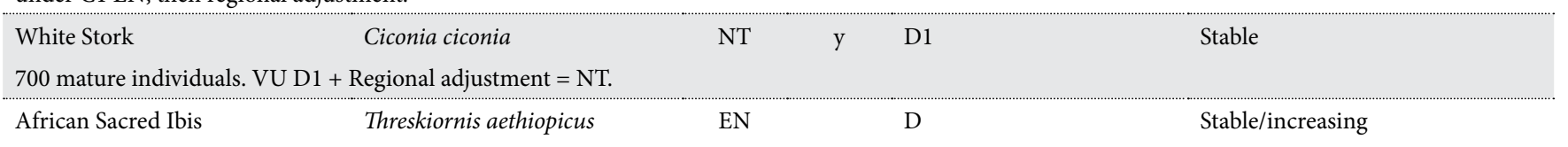

Breeds in SW Yemen - c.30 mature individuals; Iraq 100-150. So <200 mature individuals in region. EN D. Rescue effect low. Feral breeding in UAE.

\begin{tabular}{|c|c|c|c|c|}
\hline Northern Bald Ibis & Geronticus eremita & CR & $\mathrm{D}, \mathrm{C} 2 \mathrm{a}(\mathrm{i}),(\mathrm{ii}), \mathrm{B} 1+2 \mathrm{ab}(\mathrm{v})$ & Declining \\
\hline \multicolumn{5}{|c|}{ 2-3 pairs Syria. CR D, C2a(i) (ii). Rescue effect low / nil } \\
\hline Glossy Ibis & Plegadis falcinellus & LC & D1 & Possibly expanding and increasing \\
\hline
\end{tabular}

$<200$ pairs breeding in Iraq. Not confirmed in Syria. A few pairs in Arabian Peninsula. VU D1 but downlisted by two categories due to rapidly expanding global population and very high rescue potential

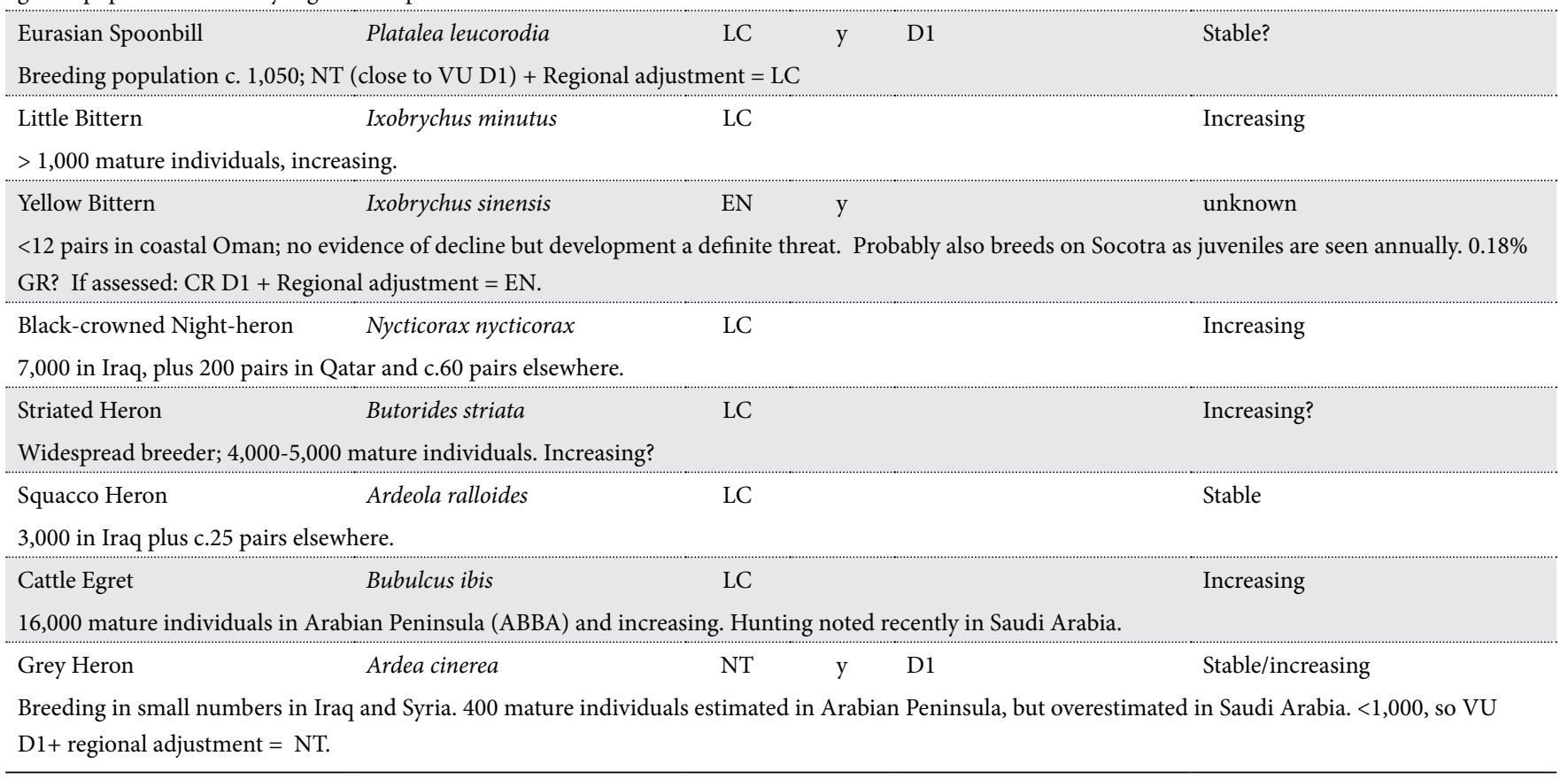




\begin{tabular}{|c|c|c|c|c|c|}
\hline Common Name & Scientific Name & Reg Cat & Reg adj & Criteria & Regional trend \\
\hline Barbary Falcon & Falco pelegrinoides & $\mathrm{VU}$ & & A2ad & Declining \\
\hline \multicolumn{6}{|c|}{$\begin{array}{l}\text { 2,600 mature individuals in Arabian Peninsula (ABBA), plus 30-50 pairs in Iraq and Syria, so }<3,000 \text { mature individuals. Evidence of decline throughout } \\
\text { region due to capture for trade. } 2004-2010: 30->10->1 \text { (MSc study). } 30 \% \text { decline suspected over } 19 \text { years. Rescue effect low, so no adjustment. May be } \\
\text { lumped with Peregrine, in which case the combined taxon will need reassessment. }\end{array}$} \\
\hline Osprey & Pandion haliaetus & $\mathrm{LC}$ & & & Stable \\
\hline
\end{tabular}

1,700 mature individuals in Arabian Peninsula. (ABBA). Thought to be stable. Threat - nest predation by white-tailed mongoose.

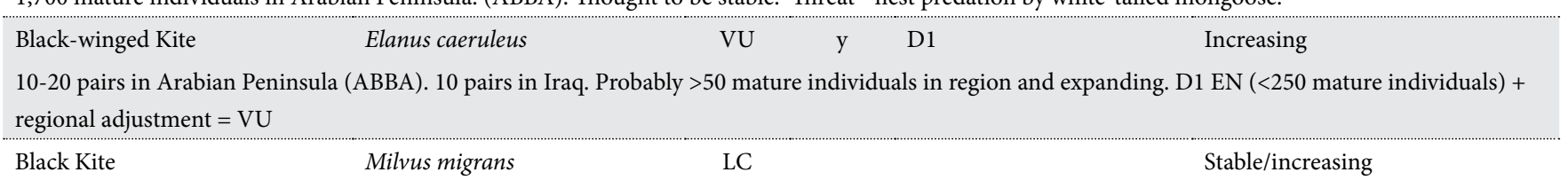

60,000 mature individuals in Arabian Peninsula (ABBA); all breeding birds in Arabian Peninsula are 'yellow-billed kite Milvus aegyptius'.

$\begin{array}{lcccc}\text { Lammergeier } & \text { Gypaetus barbatus } & \text { VU } & \text { y } & \text { D1 }\end{array}$

4,000 mature individuals and declining (ABBA), plus 1,000 in north =c. 5,000 in region. c.1900 individuals estimated on Socotra, one of the highest concentrations in the world (Porter \& Sulaiman 2012); Threats - nest predation by white-tailed mongoose. $82.5 \%$ decline in one population in Saudi Arabia. 30-49\% decline suspected over past 42 years. Rescue effect minor.

Griffon Vulture $\quad$ Gypsfulvus $\quad$ EN A2ae Declining

10,000 mature individuals and declining in Arabian Peninsula (ABBA); increasing in Jordan; declining in Syria ( $>50 \%)$, Yemen ( $>60 \%$ ), and Saudi Arabia. Vagrant in UAE). Estimated decline of $50-79 \%$ over past 43 years, EN A2 (no regional rescue effect). Note that vulture species rely on one another for foraging (M. Shobrak). Secondary poisoning, decline in large carnivores that open carcasses also had negative effect.

Lappet-faced Vulture Torgos tracheliotos $\quad$ VU $\quad$ D1 Stable/declining

Only known in Arabia since 1980s (previously misidentified). Some concentrated in Protected Areas - 20-30 pairs in some. No evidence of local vulnerability to diclofenac. Persecuted but can tolerate people. Breeds at four areas in Oman (record count 102 individuals in 2007). Maximum 600 pairs but maybe fewer? VU D1. Rescue effect not significant.
Short-toed Snake Eagle
Circaetus gallicus
VU
y D1
Stable

100-200 breeding adults in region? C.30 pairs in Jordan? 20-30 in Syria. Breeds in N Iraq; Few breeding records from Arabian Peninsula; EN D (<250 mature indivuduals) + regional adjustment $=$ VU D1

Western Marsh-harrier $\quad$ Circus aeruginosus $\quad$ NT $\quad$ y $\quad$ D1

100-250 pairs breed in southern Iraq. Formerly bred Syria. VU D1 + regional adjustment = NT. Common migrant through region.

Dark Chanting-goshawk Melierax metabates LC Probably stable

2,000-3,000 pairs in Yemen and southern Saudi Arabia (ABBA). Not threatened by trapping as not valuable - most birds trapped are released.

Gabar Goshawk Melierax gabar LC Probably stable

1,000 pairs? (ABBA) maybe more, as less conspicuous than M. metabates. Not threatened by trapping as not valuable - most birds that are trapped get released
Shikra
Accipiter badius
LC y
Probably stable

600 pairs? (ABBA) but perhaps more. Now found in Kuwait but non-breeding as yet. A few pairs now in Dubai but probably feral. Maybe NT under D1 but step down due to immigration. Not threatened by trapping as not valuable - most birds trapped are released.

Common Buzzard Buteo buteo Stable

Breeds locally in mountains of N Iraq; probably breeds in Syria. >1,000 mature individuals in Iraq; not declining. $0.004 \%$ of glob range in region. Birds in Iraq show some morphological differences.
Long-legged Buzzard
Buteo rufinus
LC
Stable

1,800 mature individuals in Arabian Peninsula (ABBA); c.2,000 mature individuals in Iraq, Syria and Jordan, so $<10,000$ mature individuals in total. No decline.

$\begin{array}{llll}\text { Socotra Buzzard } & \text { Buteo socotraensis } & \text { VU } & \text { D1 }\end{array}$

ENDEMIC. <250 pairs (Porter \& Sulaiman in prep.); no competition, no shooting or trapping; VU D1.
Tawny Eagle
Aquila rapax
EN C2a(ii)
Declining

600 mature individuals in Arabian Peninsula (ABBA); stable in Yemen, but thought to be declining overall; EN C2a(ii) (VU D1); rescue effect unlikely. 0.4\% GR.

Golden Eagle

Aquila chrysaetos

EN

$\mathrm{C} 2 \mathrm{a}(\mathrm{i})$

Declining

500 in Arabian Peninsula (ABBA); plus max 50 mature individuals in Iraq; Syria and Jordan. In total <1,000. Threat of oil exploitation in Oman. Prey

exploited by humans. EN C2a(i). Rescue effect low. 


\begin{tabular}{lcccc}
\hline Common Name & Scientific Name & Reg Cat & Reg adj & Criteria \\
\hline $\begin{array}{l}\text { Verreaux's Eagle } \\
\text { Aquila verreauxii }\end{array}$ & EN & D & Regional trend \\
120 mature individuals in Arabian Peninsula (ABBA); none in Syria and Iraq. Increasing. Stable in Oman. EN under criterion D. Unlikely rescue effect. \\
$1.4 \%$ GR
\end{tabular}

1,000 in Arabian Peninsula (ABBA); 140 mature individuals in Syria and Jordan; 100 breeding pairs in Iraq; so total of $<2,000$ mature individuals in region. Apparently stable, so LC.
Arabian Bustard
Ardeotis arabs
CR
A2,A3,A4abd; C2aii.
Very rapid decline
Perhaps also D, C2ai \& C1?

Perhaps 50 breeding females in 2010 at most, maybe as few as 20. Predicted regionally extinct by 2020. Although may be immigration from Africa, this population also decreasing so no rescue effect likely.
Houbara Bustard
Chlamydotis undulata
CR
A2,A3,A4abd. probably C1 Very rapid decline

Formerly widespread but reduced by hunting. In 2003 Oman 1 pair/80 km, but no recent sightings at all. None in Qatar in last 2 years. Must have been historically very numerous. May be a remnant population in eastern Yemen. No breeding in Jordan or Syria. $<100$ pairs now in Arabian Peninsula and perhaps <30 pairs southern Iraq. 190 Pakistani birds released recently in Yemen but these not yet countable under IUCN guidelines. Thousands are captive bred each year in UAE for hunting. Continuing decline estimated at $>85 \%$ in 3 generations. CR A $2+3+4 \mathrm{~d}$; no rescue effect, because potential source populations are also declining and the regions act as a population sink. Reassessment needed if and when released populations become established.
Water Rail
Rallus aquaticus
NT $\quad$ y D1
Uncertain

100 pairs in ABBA area (Saudi Arabia and Oman); perhaps <50 pairs Iraq. Breeds in Syria. Stable or increasing due to increase in man-made wetlands in Arabian Peninsula, but perhaps decreasing in Iraq. VU D1 + regional adjustment $=$ NT.
Purple Swamphen
Porphyrio porphyrio
LC
Stable

$>4,000$ pairs in Iraq. Bred in Kuwait 2012 \& 2013. Non-native African race has been introduced in UAE/Qatar.

\begin{tabular}{|c|c|c|c|}
\hline Common Moorhen & Gallinula chloropus & LC & Stable/increasing \\
\hline \multicolumn{4}{|c|}{ Widespread, common, and stable/increasing } \\
\hline Common Coot & Fulica atra & LC & Stable/increasing \\
\hline
\end{tabular}

Widespread, common, and stable/increasing

Eurasian Thick-knee Burhinus oedicnemus $\quad$ LC Stable/increasing

Perhaps 10,000 pairs in Iraq. Scarce breeder in Syria and Jordan. Sporadic elsewhere in Arabia (but common migrant).

Spotted Thick-knee Burhinus capensis LC

LC

Probably stable

Perhaps 1,200 pairs (ABBA). Further study of numbers and trend is recommended.
Crab Plover
Dromas ardeola
$\mathrm{VU}$
C1
Declining

Near endemic breeding species (70\% of global range). 8,000 mature individuals in 20 colonies (ABBA); declining due to egg collecting, cats and rats and also development. However, displaced birds can move to other islands in some cases. Decline estimated at $>10 \%$ in 3 generations $=\mathrm{VU} \mathrm{C} 1$. Rescue effect unlikely to be significant.

Black-winged Stilt Himantopus himantopus Increasing

5,000 in Arabian Peninsula (ABBA) and >10,000 mature individuals in region; increasing.

Pied Avocet Recurvirostra avosetta $\quad$ NT $\quad$ y $\quad$ D1

400 mature individuals in Arabian Peninsula (ABBA) plus some in Syria, so <1000 in total. VU D1 + regional adjustment $=$ NT.

Spur-winged Lapwing Vanellus spinosus $\quad$ LC Increasing

1,000 pairs in Arabian Peninsula (ABBA), plus <4,000 n Iraq; increasing.

Red-wattled Lapwing Vanellus indicus Increasing

1,700 pairs in Arabian Peninsula (ABBA); 6,000 mature individuals in Iraq; increasing

White-tailed Lapwing Vanellus leucurus LC Stable

20 pairs in Arabian Peninsula (ABBA); 7,000 mature individuals in Iraq; also breeds in Syria. Estimated $<10,000$ mature individuals in region; no evidence of decline. $20-50 \%$ of global population in region.

\begin{tabular}{lcccccccc} 
Little Ringed Plover & Charadrius dubius & LC & Increasing \\
500 pairs and increasing in Arabian Peninsula (ABBA); widespread in N and C Iraq (Salim et al. 2012). & LC \\
\hline Kentish Plover & Charadrius alexandrinus & LC & Stable
\end{tabular}

30,000 pairs in Arabian Peninsula (ABBA), plus breeds in Iraq and Syria; stable.

Greater Sand Plover Charadrius leschenaultii $\quad$ NT $\quad$ y D1

Recently bred in Kuwait and Saudi Arabia; <1,000 mature individuals breeding in region but many migrants; VU D1 + regional adjustment = NT.

Cream-coloured Courser Cursorius cursor LC Probably declining

May be 40,000 pairs in region (ABBA). Hunted as a third choice after bustards and stone-curlews. Probably declining, but not yet at rate to meet threshold for NT. 


\begin{tabular}{|c|c|c|c|c|}
\hline Common Name & Scientific Name & Reg Cat Reg adj & Criteria & Regional trend \\
\hline Collared Pratincole & Glareola pratincola & LC & & Stable or increasing \\
\hline \multicolumn{5}{|c|}{ Only breeds in Iraq within the region; perhaps $>20,000$ pairs. } \\
\hline White-eyed Gull & Larus leucophthalmu & LC & & Probably stable \\
\hline
\end{tabular}

Endemic to Red Sea Basin. Arabian breeding population c.8,000 pairs (ABBA) and probably stable. Global status should probably be revised (currently NT). Fairly minor threats are egg collection for food and oil spills.

\begin{tabular}{|c|c|c|c|}
\hline Sooty Gull & Larus hemprichii & LC & Stable/increasing \\
\hline \multicolumn{4}{|c|}{$26,000+$ pairs in region $(\mathrm{ABBA})$; stable/increasing. } \\
\hline Slender-billed Gull & Larus genei & $\mathrm{LC}$ & Fluctuating \\
\hline
\end{tabular}
but these are widespread.
Gull-billed Tern
Sterna nilotica
LC
Stable

Up to 1,000 pairs in Arabian Peninsula (ABBA - most Kuwait) plus c.600 pairs in Iraq and < 10 pairs in Syria. May breed inland at temporary wetlands and a few other sites on coast.

Caspian Tern Sterna caspia LC Stable

500 pairs in Arabian Peninsula (ABBA), 400 pairs in Iraq and c.20 in Syria.

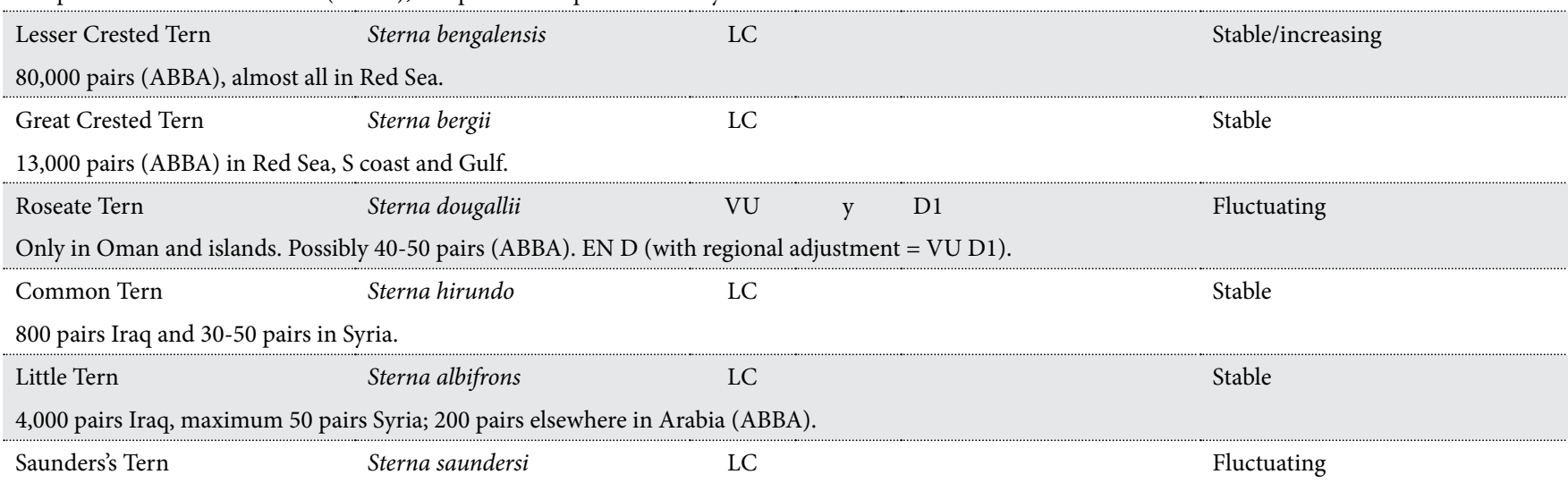

c.4,000 pairs around coast (ABBA). Possible decline of 1,000 to 100 reported at same sites in UAE over 15 years and 150 died recently from Newcastle disease. Population fluctuating and decline not suspected to have reached threshold for NT.

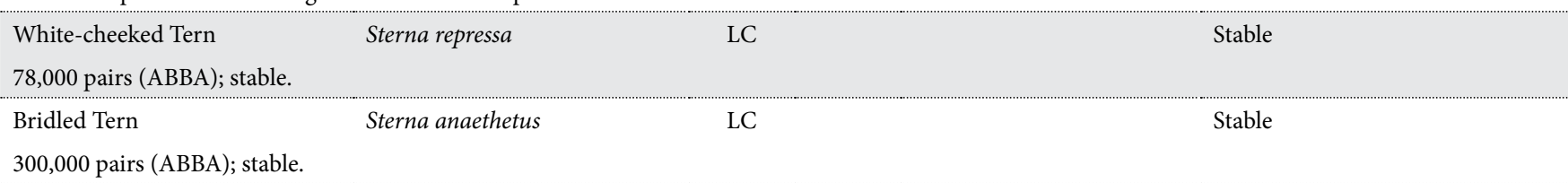

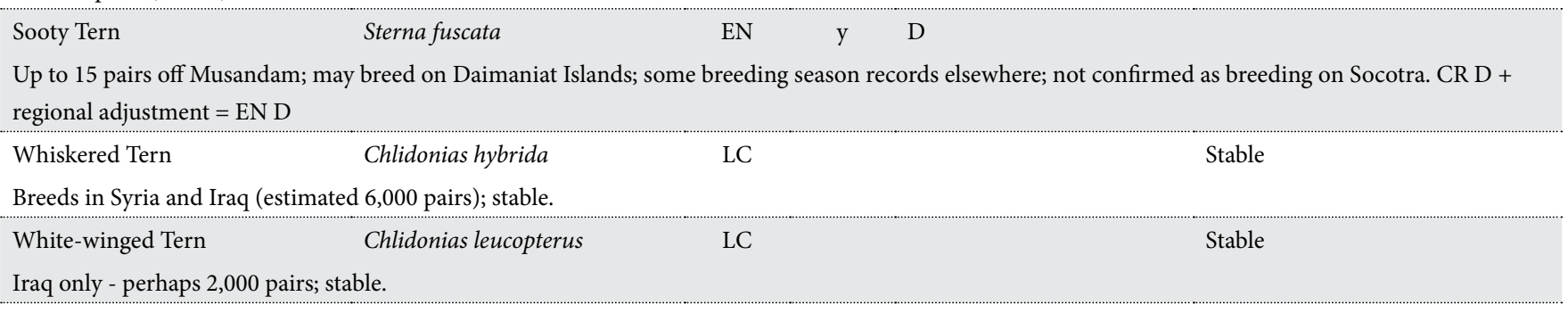

Brown Noddy Anous stolidus LC

11,000 pairs (ABBA); stable.

Pin-tailed Sandgrouse $\quad$ Pterocles alchata $\quad$ LC Decreasing

Breeds in Iraq, Syria, Israel / Palestine; possibly elsewhere. Population size unknown but estimated well in excess of 10,000 mature individuals in Iraq alone. Hunted by professionals and locals in Iraq, including harvesting at water holes. Decreasing but at an unknown rate; provisionally LC, but needs monitoring to evaluate rate of decline from hunting, in which case, a higher category of threat may be appropriate.

Chestnut-bellied Sandgrouse Pterocles exustus LC Stable

80,000 pairs (ABBA). Decreasing in UAE due to disturbance/pressure on habitat but spreads back once protected. Increasing elsewhere where favoured by expansion in irrigated fields.
Spotted Sandgrouse
Pterocles senegallus
LC
Decreasing

c.3,000 pairs in Iraq and 10,000 pairs in Arabian Peninsula (ABBA). Big historical decrease towards NW of range and Saudi Arabia but long time ago, most of currently-mapped Saudi range is historical. Many are shot in Saudi Arabia. 


\begin{tabular}{llcll}
\hline Common Name & Scientific Name & Reg Cat & Reg adj & Criteria \\
\hline Black-bellied Sandgrouse & Pterocles orientalis & EN & C2a(ii)
\end{tabular}

c. 2500 birds in northern Negev in the 1980s but fewer now and declining; rescue effect not significant.

$\begin{array}{lccccc}\text { Crowned Sandgrouse } & \text { Pterocles coronatus } & \text { LC } & \text { Stable } \\ \text { c.6,000 pairs }(\mathrm{ABBA})-\text { most in Oman and a few scattered other populations. } & \text { LC } & \text { Stable } \\ \text { Lichtenstein's Sandgrouse } & \text { Pterocles lichtensteinii } & \text { L }\end{array}$

60,000-70,000 pairs (ABBA). Inhabits rocky areas which are not under any obvious threat. Crepuscular/nocturnal so not vulnerable to hunting.
Rock Pigeon
Columba livia
LC
Stable?

Widespread across the region (including wild and feral/town birds); 950,000 pairs (ABBA) plus more in north. Stable.

Common Wood-pigeon Columba palumbus $\quad$ LC Stable

Within region breeds mainly in Iraq (estimated c.400,000). There is a small isolated population on Jebel Akhdar, Oman, estimated at 1,000 pairs (ABBA).

$\begin{array}{llll}\text { African Olive-pigeon } & \text { Columba arquatrix } & \text { EN } & \text { D } \\ 100 \text { pairs in SW of region (ABBA). EN D; significant rescue effect unlikely, even though a huge range in Africa. } & \text { Stable } \\ \text { European Turtle-dove } & \text { Streptopelia turtur } & \text { LC } & \text { Uncertain }\end{array}$

European Turtle-dove Streptopelia turtur $\quad$ LC $\quad$ Uncertain

2,500 pairs in Arabian Peninsula, possibly more (ABBA); 1,000+ mature individuals in Syria and in Iraq. $<10,000$ mature individuals in region; possibly increasing in Iraq; targeted by hunters in Saudi Arabia and Syria. No evidence that decline has reached the threshold for NT.

\begin{tabular}{llll}
$\begin{array}{l}\text { Dusky Turtle-dove } \\
\begin{array}{l}\text { Streptopelia lugens } \\
90,000 \text { pairs in SW of region (ABBA); stable. }\end{array}\end{array}$ & LC & Stable \\
\hline $\begin{array}{l}\text { Red-eyed Dove } \\
\text { Streptopelia semitorquata }\end{array}$ & LC & Stable
\end{tabular}

100,000 pairs in SW of region (ABBA); stable.

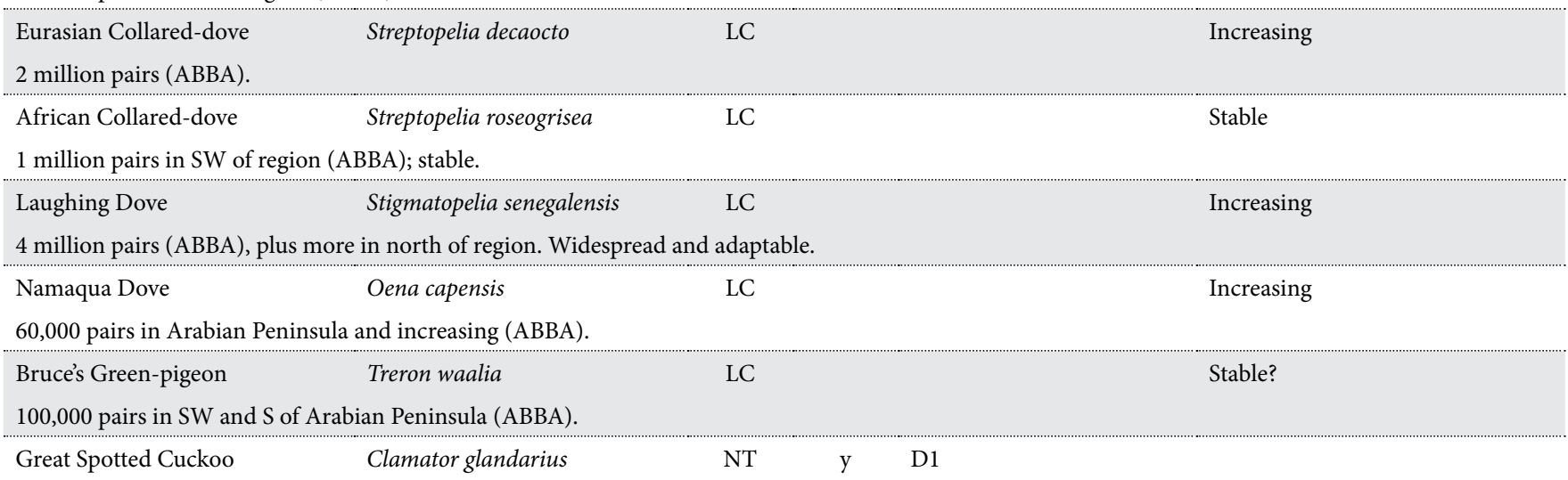

Local breeder in N Iraq, Israel / Palestine; Lebanon; probably Syria; present in Jordan in summer but breeding not yet confirmed. Estimated $<1,000$ birds = VU D1; with rescue effect $=$ NT.
Common Cuckoo
Cuculus canorus
NT
y D1
Stable?

Breeds in Iraq (100 pairs), Jordan (200-250), Lebanon, Israel / Palestine (numbers unknown); may breed Syria. May be <1,000 mature individuals in region, so precautionary VU D1, with rescue effect $=$ NT.

Didric Cuckoo Chrysococcyx caprius $\quad$ LC y

600 pairs including 100 in Oman (ABBA). Regional population c.1,200 so NT (close to VU D1) but with regional adjustment due to potential immigration $=\mathrm{LC}$.
Klaas's Cuckoo
Chrysococcyx klaas
NT
y D1
400 pairs in SW of region (ABBA); VU D1, with regional adjustment - NT.
White-browed Coucal Centropus superciliosus LC
LC Stable

14,000 pairs in SW Arabia and Socotra (ABBA); stable.
Barn Owl
Tyto alba
LC
Increasing?

2,000 pairs in Arabian Peninsula, maybe more (ABBA); perhaps 500 in Iraq, and many in Syria; breeds in Lebanon, Israel / Palestine. Possibly increasing with spread of irrigated agriculture. Not declining.
Pallid Scops-owl
Otus brucei
LC
Stable

2,700 pairs in Oman and UAE (ABBA) plus maximum 100 pairs in Iraq; stable.
Common Scops-owl
Otus scops
LC
Stable

Breeds in Iraq (perhaps 800 pairs) and widely along the western edge of the region; stable.

African Scops-owl

Otus senegalensis

LC

Stable

Breeds in SW and S of region. 30,000 pairs (ABBA). Arabian birds may be a separate form - Arabian Scops-owl Otus (senegalensis) pamelae. 


\begin{tabular}{|c|c|c|c|c|c|}
\hline Common Name & Scientific Name & Reg Cat & Reg adj & Criteria & Regional trend \\
\hline Scotra Scops Owl & Otus socotranus & LC & & & \\
\hline \multicolumn{6}{|c|}{$\begin{array}{l}\text { ENDEMIC TO SOCOTRA. Recently described as a distinct species (Pons et al. 2013). Estimated c.1,000 pairs (Porter \& Suleiman } 2013 \text { ). No threats. } \\
\text { Inhabits palm groves which are probably expanding. Least Concern. }\end{array}$} \\
\hline Eurasian Eagle-owl & Bubo bubo & LC & & & Stable \\
\hline
\end{tabular}

Perhaps 400 pairs in Iraq; also breeds locally in Jordan, Israel / Palestine and Syria. Regional population estimated at >1000; Stable.

Pharaoh Eagle-owl Bubo ascalaphus Stable/increasing

At least 2,500 pairs in Arabian Peninsula (ABBA), plus c.50 pairs in Iraq and also breeds in Syria; stable.

Spotted Eagle-owl Bubo africanus LC Stable

2,000 pairs (ABBA) and few threats. Potential Arabian endemic if split from African birds

$\begin{array}{lll}\text { Brown Fish-owl Ketupa zeylonensis } & \text { CR } \\ \text { Formerly bred in Iraq (1920s), Israel / Palestine and Jordan (possibly a rare breeder in Yarmuk Valley; Andrews 2005). It may be Regionally Extinct, but }\end{array}$ possible that a breeding population is still present, especially in view of recent rediscoveries of the species in Turkey (R. Porter, pers. comm.). If so, numbers are almost certainly very small and $<50$ mature individuals, thus qualifying for $\mathrm{CR}$ under criterion $\mathrm{D}$. A significant rescue effect is unlikely.
Tawny Owl
Strix aluco
LC
Stable

Breeds locally along the western / Mediterranean edge of the region; not confirmed to breed in Iraq. Stable. Estimated $>1,000$ mature individuals.
Hume's Owl
Strix butleri
LC
Stable?

3,000 pairs in Arabian Peninsula (ABBA); also breeds in S Jordan and Israel / Palestine. Believed to be stable.

Little Owl Athene noctua LC Stable/declining

5,800 pairs in Arabian Peninsula (ABBA); also breeds widely in the north of the region; stable. 'Lilith Owl' A.n. lilith (a very pale form) is rare, possibly $<1,000$ individuals), but taxonomic split is not confirmed, so DD.

$\begin{array}{lcccc}\text { Egyptian Nightjar } & \text { Caprimulgus aegyptius } & \text { LC } & \text { Stable } \\ \text { Estimated }>15,000 \text { mature individuals in Iraq; has bred Jordan. } & \text { LC } & \text { Saprimulgus nubicus } & \text { Stable? }\end{array}$

5,000 pairs in SW of region (ABBA) including c.200 mature individuals on Socotra. Stable except in northern part of range in Saudi Arabia where farming is in decline due to reduced water availability, so habitat is declining.

Montane Nightjar Caprimulgus poliocephalus LC Leclining

1,400 pairs in SW (ABBA); $21 \%$ of global range. Juniper woodland habitat is declining and population suspected to be declining at an unknown rate, but likely $<20 \%$. But could be approaching NT or VU under criterion $\mathrm{C} 1$.

Plain Nightjar $\quad$ Caprimulgus inornatus $\quad$ LC Stable

2,000 pairs in SW and S of region (ABBA); stable.
African Palm-swift
Cypsiurus parvus
LC
Stable/declining

15,000 pairs in SW of region (ABBA). Possibly some local declines due to pesticide application and development, but not suspected to reach the threshold for NT.

Alpine Swift Tachymarptis melba SC L

11,000 pairs in Arabian Peninsula (ABBA) plus more in $\mathrm{N}$ of region.
Common Swift
Apus apus
LC
Stable

Breeds in Iraq, Syria and along the Mediterranean edge of the region. Estimated 300 pairs in Iraq, and as many or more in Syria and the west of the region; $>1000$ in total. Not declining.

Pallid Swift Apus pallidus IC L Increasing

At least 25,000 pairs in Arabian Peninsula but could be 200,000 (ABBA); Increasing and adapting to cities?
Forbes-Watson's Swift
Apus berliozi
LC
Stable

Breeding population unknown; number of individuals in any one year unlikely to exceed 1000, but transect counts suggest could be 2,400 (Porter \& Suleiman 2013). No obvious threats; breeds on cliffs. Overlooked until recently.

Little Swift Apus affinis $\quad$ LC

30,000 pairs in Arabian Peninsula (ABBA) and perhaps 800 pairs in Iraq.

$\begin{array}{llll}\text { European Roller } \quad \text { Coracias garrulus } & \text { NT } & \text { y } & \text { D1 }\end{array}$

c.200 pairs in Iraq. Fairly common in Jordan and Syria but no numbers. Regional population uncertain but could be either side of 1,000 mature individuals. Precautionary could be fewer than 1,000 so VU D1, regional adjustment due to massive potential for rescue from migrants.
Abyssinian Roller
Coracias abyssinicus
LC
Assumed to be stable

2,500 pairs (ABBA) in Yemen and SW Saudi Arabia.
Indian Roller
Coracias benghalensis
LC
Increasing

c.15,000 pairs Arabian Peninsula, and 2,500 pairs Iraq? Major spread and increase in UAE 


\begin{tabular}{|c|c|c|c|c|c|}
\hline Common Name & Scientific Name & Reg Cat & Reg adj & Criteria & Regional trend \\
\hline White-throated Kingfisher & Halcyon smyrnensis & $\mathrm{LC}$ & & & Assumed to be stable \\
\hline
\end{tabular}

Grey-headed Kingfisher Halcyon leucocephala $\quad$ LC

Perhaps 6,000 pairs (ABBA). May be declining in some areas due to loss of coastal habitat but increasing in irrigated areas, so assume stable overall.

Collared Kingfisher $\quad$ Todiramphus chloris $\quad$ EN $\quad$ A2c $+3 c+4 c$; B2abi,ii,iii, iv,v Declining

400 pairs in Arabian Peninsula (ABBA); big decline in Saudi Arabia due to degradation of mangroves with 50-55\% lost; decline in Kalba (UAE) - 1995, 88110 birds, down to 52-70 in 2011 with almost a third of the mangroves cut. AOO $<500 \mathrm{~km}^{2}$; severely fragmented; EN A2c,3c,4c; B2abi,ii,iii, iv,v; kalbensis CR B2abii,iii,v; C2aii - AOO 4-5 km². Needs old trees for nesting and regeneration very limited. Research in nest site preferences under way in UAE.

Common Kingfisher Alcedo atthis $\quad$ NT $\quad$ y $\quad$ D1

Breeds in S Iraq and probably N Iraq; probably breeds in Syria. 100-200 mature individuals in Iraq. Estimated 250-1000 in region; D1 VU + regional adjustment $=$ NT

Pied Kingfisher Ceryle rudis DC Declining

15,000 mature individuals in Iraq; LC but declining.

White-throated Bee-eater $\quad$ Merops albicollis
4,000 pairs in SW of region (ABBA); no decline.

Little Green Bee-eater $\quad$ Merops orientalis $\quad$ LC Stable/increasing

150,000 pairs in Arabian Peninsula (ABBA); likely to be split as M. cyanophrys which would be an Arabian endemic.
Blue-cheeked Bee-eater
Merops persicus
$\mathrm{LC}$
Stable
1,600 pairs in Arabian Peninsula (ABBA); many in Iraq so >6,000 mature individuals in region; flexible habitat requirements; no evidence of declines.

European Bee-eater Merops apiaster LC Declining

1,500 pairs in Arabian Peninsula (ABBA); plus populations in Iraq, N Syria, Jordan; so estimated >10,000 birds; persecuted on migration and by beekeepers; declining in Oman due to habitat loss; also sharp decline in UAE, but not thought to have reached $30 \%$ over 20 years.

Eurasian Hoopoe Upupa epops LC Stable

46,000 pairs ABBA) plus others in north of region so c.100,000 in region; has de facto protection owing to reference in Quran. Possible competition for nest sites with expanding Common Myna.

African Grey Hornbill Tockus nasutus TC Stable

8,000 pairs in SW of region (ABBA); stable in Yemen.

Arabian Woodpecker Dendrocopos dorae $\quad$ VU A2ac+3c+4ac Declining

7,500 pairs in SW of region (ABBA). Declined notably since 1970s-1980s and become much more difficult to see. E.g. 3-6 known sites in Yemen no longer occupied (R. Porter); also local disappearances in Saudi Arabia and an estimated 20-40\% decline since 1997 (M. Shobrak). Overall, the estimated decline is $>30 \%$ but $<50 \%$ over 3 generations. Threats are mainly connected with loss of acacia woodland, cut for timber \& fodder and regeneration inhibited by aridification and growing numbers of grazing livestock. These threats especially affect larger trees which contain holes for nesting; the species likes to feed in outer branches which are often lopped for fodder. Withdrawal of government subsidies for LPG in Yemen has increased demand for fuel wood. Granite quarrying in the mountains of Saudi Arabia as well as building and construction destroys more habitat. There may be competition for nest holes from other species, e.g. Amethyst Starling Cinnyricinculus leucogaster. Increasingly heavy recreational use of woodland reserves such as Raydah brings disturbance.
Middle Spotted Woodpecker
Dendrocopos medius
$\mathrm{VU}$
$\mathrm{C} 2 \mathrm{a}(\mathrm{i})$
Declining

Breeds in N Iraq (500 pairs) and NW Syria (a few). Declining; VU C2a(i) and may be close to EN in region. Rescue effect from Iran assumed to be low as this population also declining.
Syrian Woodpecker
Dendrocopos syriacus
LC
Stable/declining

2,000 pairs in Iraq plus unknown number in Syria/Jordan/Palestine/Israel. Declining in Iraq and Syria. Stable elsewhere.
Black-crowned Tchagra
Tchagra senegalus
LC
Increasing?

$7,000-8,000$ pairs if 1 per $20 \mathrm{~km}^{2}$ (ABBA)
Great Grey Shrike
Lanius excubitor
LC
Possibly increasing

c.250,000 pairs in Arabian Peninsula (ABBA); perhaps 100 pairs in Iraq. Split by many as Southern Grey Shrike Lanius meridionalis, but not currently split by BirdLife International. Near endemic as meridionalis.
Woodchat Shrike
Lanius senator
LC

c.500 pairs in Iraq and unknown number in Syria, Jordan, Lebanon. One record Kuwait.

$\begin{array}{lcc}\text { Masked Shrike } & \begin{array}{l}\text { Lanius nubicus } \\ 800 \text { pairs in Iraq and unknown number in Syria, Palestine, Lebanon. }\end{array} & \text { LC } \\ \text { Eurasian Golden Oriole } & \text { Oriolus oriolus } & \text { LC }\end{array}$

100 mature individuals in Arabian Peninsula (ABBA); breeding record in Kuwait; with other populations in north, probably $>1000$ mature individuals in region. 


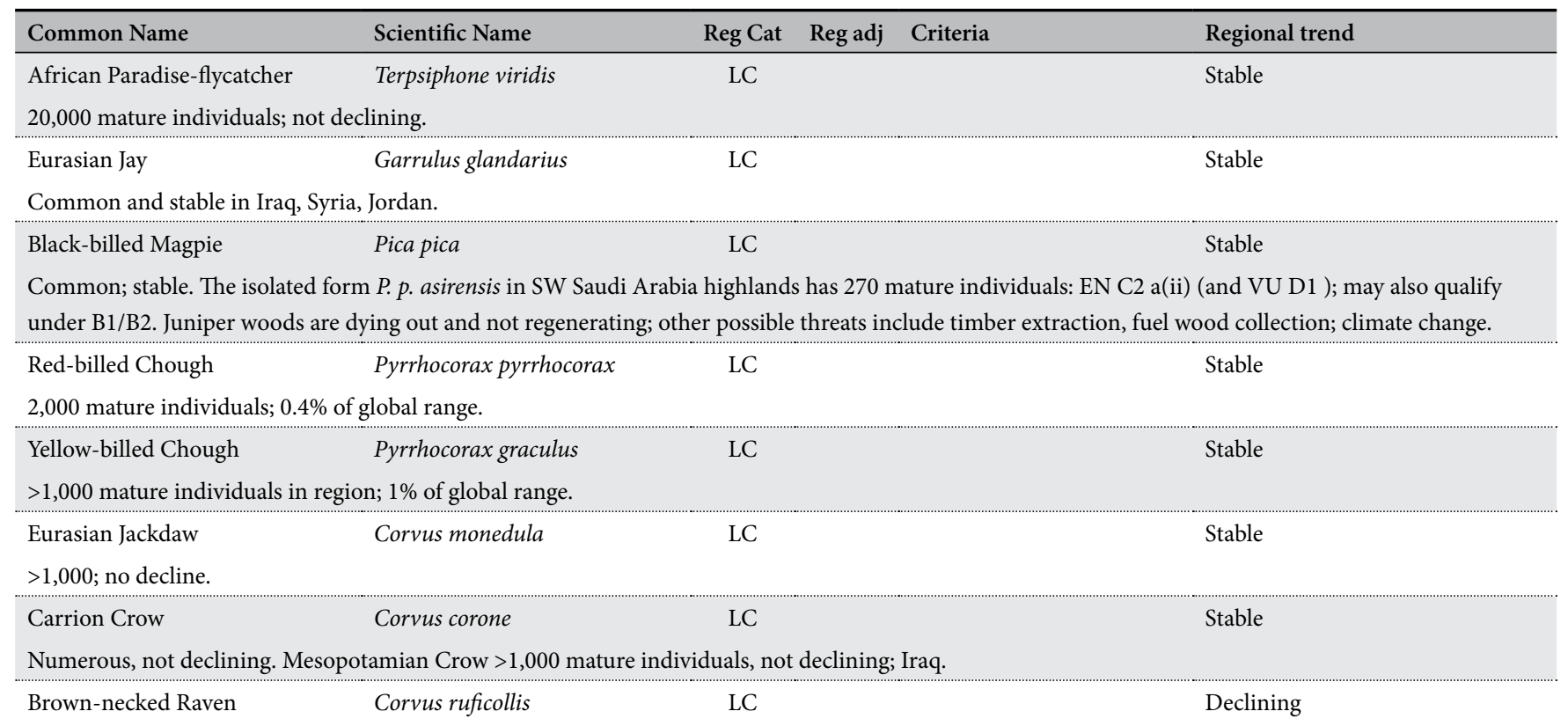

150,000 pairs in Arabian Peninsula (ABBA), plus more in Iraq and Jordan; declining in UAE probably owing to habitat degradation through overgrazing. Possibly out-competed by Fan-tailed Raven C. rhipidurus in places?

\begin{tabular}{|c|c|c|c|}
\hline \multicolumn{4}{|c|}{ 1,000 pairs Iraq plus presumably good numbers in Syria/Jordan etc. } \\
\hline $\begin{array}{l}\text { Fan-tailed Raven } \\
\text { c. } 150,000 \text { pairs (ABBA); }\end{array}$ & \multicolumn{2}{|c|}{ c.150,000 pairs (ABBA); stable. } & Stable \\
\hline \multicolumn{4}{|c|}{$\begin{array}{l}\text { Only breeds in Iraq in the region; population size is unknown, but estimated to exceed 1,000 mature individuals as global population is estimated at } \\
>10,000 \text { (BirdLife International 2013) and Arabian range is 30\% of the total. }\end{array}$} \\
\hline $\begin{array}{l}\text { Sombre Tit } \\
1,000 \text { pairs in Iraq, plus u }\end{array}$ & \multicolumn{2}{|c|}{ 1,000 pairs in Iraq, plus unknown number in Syria; not declining. } & Presumed stable \\
\hline $\begin{array}{l}\text { Coal Tit } \\
\text { Estimated several thousa }\end{array}$ & \multicolumn{2}{|c|}{ Estimated several thousand in Syria; also breeds in Lebanon. } & Stable \\
\hline $\begin{array}{l}\text { Great Tit } \\
10,000+\text { pairs in Iraq plus }\end{array}$ & \multicolumn{2}{|c|}{$10,000+$ pairs in Iraq plus unknown numbers elsewhere in north of region. } & Stable \\
\hline \multicolumn{4}{|c|}{ Perhaps 3,000 pairs in Iraq, and unknown number in Syria and Jordan. } \\
\hline $\begin{array}{l}\text { Eurasian Penduline-tit } \\
\text { Syria only - unknown po }\end{array}$ & \multicolumn{2}{|c|}{ Syria only - unknown population size and trend. } & Uncertain \\
\hline $\begin{array}{l}\text { Sand Martin } \\
\text { c. } 25,000-30,000 \text { pairs in I }\end{array}$ & \multicolumn{2}{|c|}{ c.25,000-30,000 pairs in Iraq. Unknown number in Syria } & Unknown \\
\hline \multicolumn{4}{|c|}{ Breeds locally in mountains of $\mathrm{N}$ and $\mathrm{E}$ Iraq, estimated >1000 mature individuals. } \\
\hline \multicolumn{4}{|c|}{ 150,000 pairs in Arabian Peninsula (ABBA); not declining. } \\
\hline \multicolumn{4}{|c|}{ Breeds in north and west of the region. Numbers estimated at $>1,000$ and not declining. } \\
\hline \multicolumn{4}{|c|}{ Breeds in north and west of the region. Numbers estimated at $>1,000$ and not declining. } \\
\hline $\begin{array}{l}\text { Singing Bushlark } \\
4,500 \text { pairs in Arabian Pe }\end{array}$ & $\begin{array}{l}\text { Mirafra cantillans } \\
\text { ABBA); stable or increa }\end{array}$ & LC & Stable/increasing \\
\hline Greater Hoopoe-lark & Alaemon alaudipes & $\mathrm{LC}$ & Stable \\
\hline
\end{tabular}




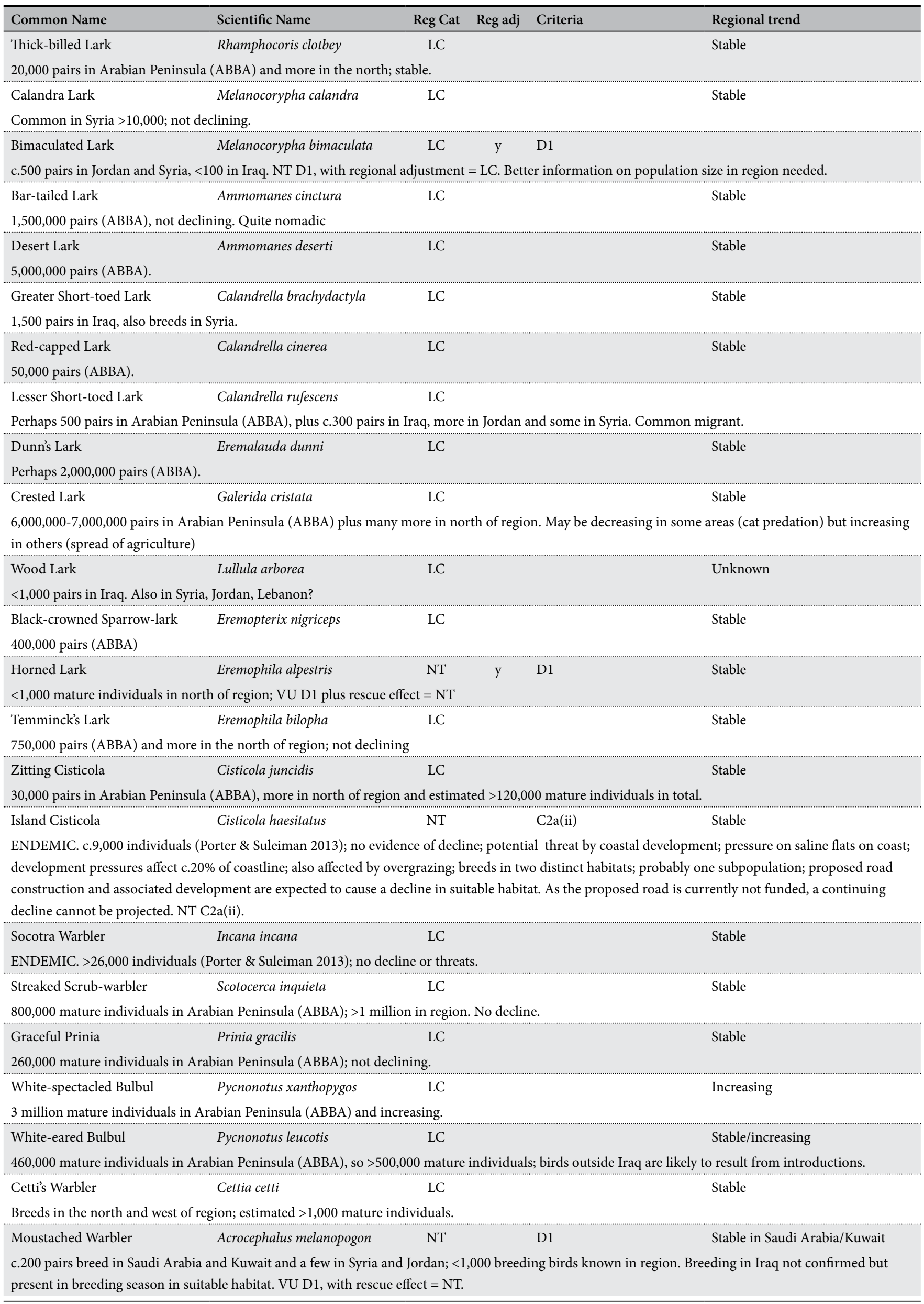




\begin{tabular}{|c|c|c|c|c|c|}
\hline Common Name & Scientific Name & Reg Cat & Reg adj & Criteria & Regional trend \\
\hline Eurasian Reed-warbler. & Acrocephalus scirpaceus & LC & & & Increasing (Arabia) \\
\hline
\end{tabular}

1,100 pairs (ABBA) plus good numbers in Syria and Jordan and $<100$ pairs in Iraq. Increasing breeding in Arabia. An estimated further 3,000 pairs along coast of Saudi Arabia and Yemen have been separated as Red Sea or Mangrove Reed Warbler A. avicenniae (formerly considered African Reed Warbler A. baeticatus), but this split not yet confirmed by BirdLife International. These populations declining owing to destruction of mangroves at estimated rate $>30 \%$ in 3 generations. If this taxon assessed separately, would be VU C2a(ii) plus rescue effect from African side of Red Sea $=$ NT.
Great Reed-warbler
Acrocephalus arundinaceus
LC $y \quad$ D1
Stable/increasing

200 pairs Arabian Peninsula (ABBA); 300+ pairs Iraq, Small numbers in Syria and Jordan. Perhaps NT D1 as smallish population, but significant rescue effect $=$ LC.

Clamorous Reed-warbler Acrocephalus stentoreus $\quad$ LC Increasing

5,000 pairs in Arabian Peninsula plus small numbers in Syria and Jordan.
Basra Reed-warbler
Acrocephalus griseldis
EN
B2ab(i,ii,iii,iv,v)
Unknown

Breeding is concentrated in the southern and central marshes of Iraq where the current population is estimated at $<5,000$ pairs (Mudhafar Salim/Nature Iraq, in litt.). Bred in Kuwait 2008-2009 and is an annual summer visitor so there may be a small isolated breeding population (M Pope, pers. comm.). Probably breeds in the Eastern Province of Saudi Arabia and in the Riyadh area (M. Shobrak, pers. comm.). Recently found breeding in Hula Valley, Israel (Perlman \& Meyrav 2009). Draining of the marshes meant that $<10 \%$ of the original extent remained in 2003. Following re-flooding, the marshes reached a peak of $65 \%$ of the 1970 s area in 2008 , before declining again to $55 \%$. The marshes are currently being degraded by drying and extraction; a new embankment on the Iranian side of the border is preventing water flow to many marshes while proposed dams upstream on the Tigris and Euphrates pose further threats to the water supply. Basra Reed-warbler is a very selective breeder with precise habitat requirements: medium-high reed edges with open water (rarely found deep inside reed beds), water depth $50-100 \mathrm{~cm}$, and good water quality (a survey of 18 sites found a positive correlation between occurrence and water quality). Nests in reeds with diameter $50-100 \mathrm{~mm}$ ( $80 \%$ of cut reeds are this size which is also used for reed houses) so is under threat. The Area of Occupancy is estimated at $<500 \mathrm{~km}^{2}$ and there are $<5$ locations. Likely also meets VU C2a(ii).

Eastern Olivaceous Warbler Hippolais pallida Stable

c.2,500 pairs in Arabian Peninsula (ABBA); c.4,000 pairs in Iraq, fairly numerous in Syria, also breeds in Jordan.

$\begin{array}{lcc}\text { Upcher's Warbler } & \text { Hippolais languida } & \text { LC } \\ \text { Perhaps } 1,000 \text { pairs in Iraq, good numbers in Jordan, a few in eastern Syria. } & \text { LC } & \text { Stable } \\ \text { Olive-tree Warbler } & \text { Hippolais olivetorum } & \text { Stable }\end{array}$

$>1,000$ mature individuals in NW of region; $8 \%$ of glob range in region so extrapolation =2,640.

$\begin{array}{lcccc}\text { Sykes's Warbler } & \text { Hippolais rama } & \text { EN } & \text { y } & \text { D } \\ 15 \text { breeding pairs at Kalba, UAE in } 1995 ; & 9 \text { individuals singing 2012. Oman }- \text { unconfirmed breeding. CR D, with rescue effect = EN. } \\ \text { Brown Woodland-warbler } & \text { Phylloscopus umbrovirens } & \text { LC } & \text { Declining }\end{array}$

70,000 pairs in SW of region (ABBA); thought to be declining owing to predation by cats and pressure on Juniper woodland.
Yemen Warbler
Sylvia buryi
NT
$\mathrm{A} 2 \mathrm{c}+3 \mathrm{c}+4 \mathrm{c}$
Declining

ENDEMIC. 9,000 pairs in SW (ABBA), a higher estimate than that used in current IUCN Red List account $(<10,000)$. One survey by Steve Newton in a protected area in Saudi Arabia recorded $>50$ pairs in $12 \mathrm{~km}^{2}$. Relies on mature/old acacia trees in Yemen and this habitat is under pressure; in Saudi Arabia, it occurs also in junipers and may be found in any bushy country. Habitat is patchy, with smaller and more fragmented patches in the north of its range. Estimated to have declined by $>20 \%$ but less than $30 \%$ over 12 years ( 3 generations) based on anecdotal evidence and habitat loss. NT, as approaching VU under criterion A. Current global assessment, VU C2a(ii), may require revision.

Blackcap Sylvia atricapilla LC

Estimated a few hundred mature individuals in Syria and may be in decline; possibly around 1000 in total and strong rescue effect.

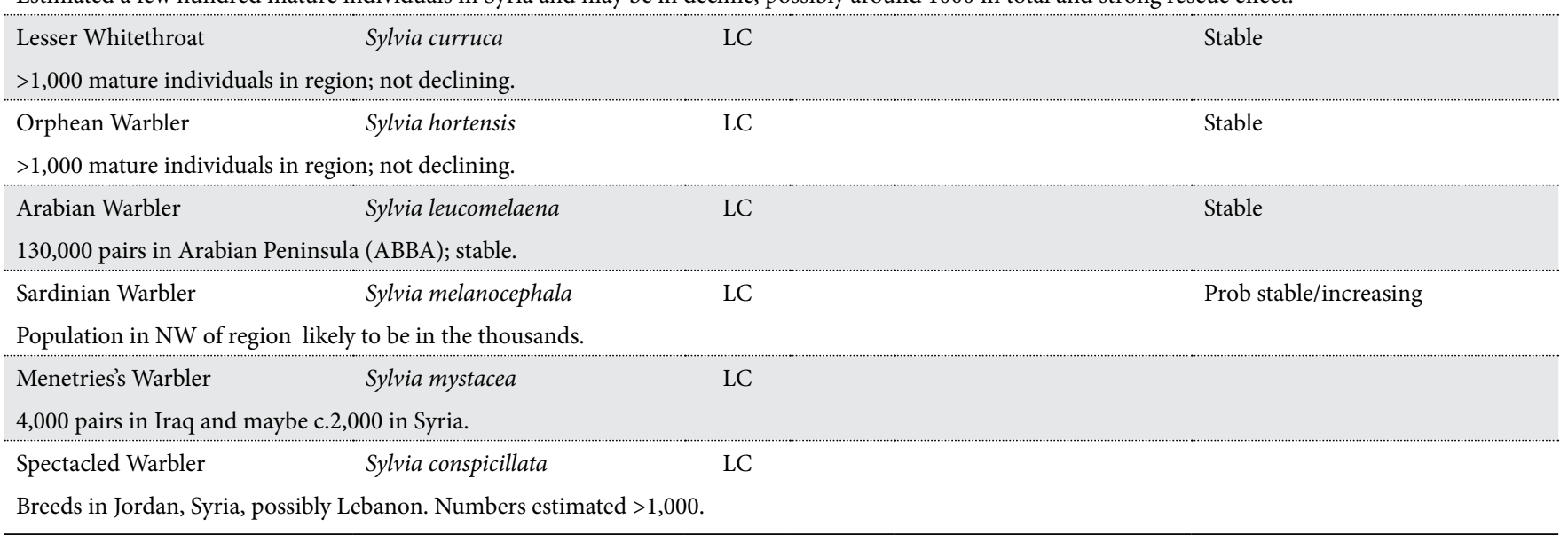




\begin{tabular}{|c|c|c|c|c|c|}
\hline Common Name & Scientific Name & Reg Cat & Reg adj & Criteria & Regional trend \\
\hline Iraq Babbler & Turdoides altirostris & LC & & & Increasing \\
\hline \multicolumn{6}{|c|}{$\begin{array}{l}\text { Near-endemic. c. 5,000 mature individuals in Iraq with more in Syria (c.1,000 mature individuals at Sabkhat al Jabboul in Syria) so perhaps } 7,000 \text { mature } \\
\text { individuals in total. Found on edges of canals and rivers and in reedbeds. May have special habitat requirements, as many transects along Tigris and } \\
\text { Euphrates do not have nests. Range is expanding so numbers inferred to be increasing. }\end{array}$} \\
\hline Common Babbler & Turdoides caudata & LC & & & Stable \\
\hline
\end{tabular}

5,000 pairs in Iraq, plus a few dozen in Kuwait

\begin{tabular}{|c|c|c|c|}
\hline $\begin{array}{l}\text { Arabian Babbler } \\
\text { 150,000 pairs (ABBA). Stab }\end{array}$ & Turdoides squamiceps & LC & Stable \\
\hline White-breasted White-eye & Zosterops abyssinicus & LC & Stable \\
\hline
\end{tabular}
Oriental White-eye
Zosterops palpebrosus
EN
D
Stable?

Previously estimated at 100 birds, and max 60 pairs? (ABBA). Possibly introduced, or a one-off natural colonisation. Significant rescue effect unlikely given lack of records elsewhere in region. So, EN D, assuming occurrence is natural.

Winter Wren Troglodytes troglodytes LC

Maybe 150 pairs in Iraq, also breeds in Jordan, Syria, Lebanon. Total population estimated > 1,000 mature individuals.

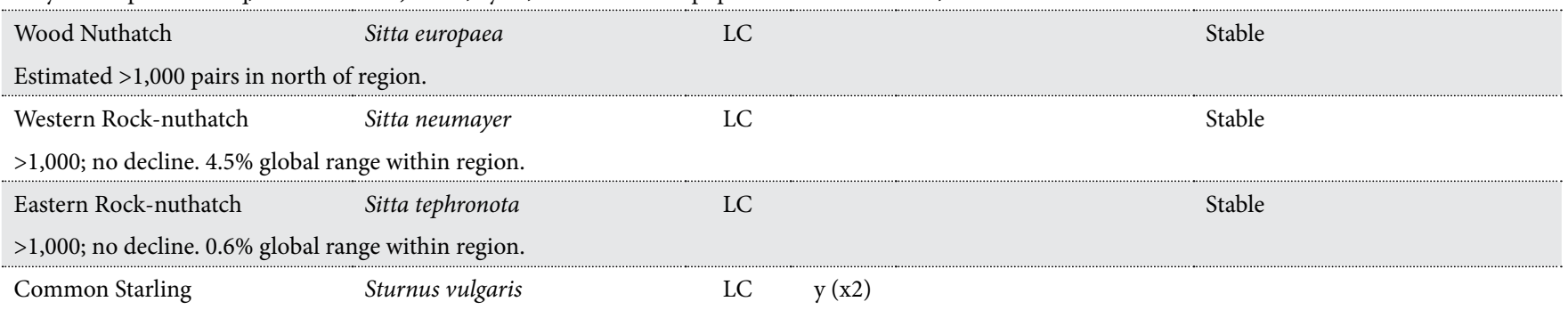

Marginal to region but expanding; breeds in N Iraq, N Syria and UAE; LC through two-step regional adjustment

Tristram's Starling Onychognathus tristramii $\quad$ LC Stable

Near-endemic. 100,000 pairs in Arabian Peninsula (ABBA), plus more in Jordan.

Somali Starling Onychognathus blythii $\quad$ LC 0

Not endemic but only on Socotra; c.102,000 individuals (Porter \& Suleiman 2013). Feeds on fruits of the dragon's blood tree. Stable. May be in competition with Socotra Starling?
Socotra Starling
Onychognathus frater
LC
Stable

ENDEMIC. Over 25,000 individuals (Porter \& Suleiman 2013); no decline, no threats

Yemen Thrush $\quad$ Turdus menachensis $\quad$ LC Declining

ENDEMIC. 10,000 pairs (ABBA); more varied habitat than Arabian Woodpecker and Yemen Warbler; found in woodland, parks, gardens etc.; very adaptable. May be declining but $<20 \%$ in 3 generations.
Eurasian Blackbird
Turdus merula
LC

Breeds in Lebanon, Syria, Iraq (widespread in N Iraq). Perhaps 1,500 in Iraq.

Mistle Thrush

Turdus viscivorus

LC

200 pairs in Iraq, low hundreds in Syria and some also Jordan. >1,000 mature individuals.

Common Nightingale Luscinia megarhynchos LC

Perhaps 800 pairs Iraq, quite numerous in Syria; $>1,000$ mature individuals.

White-throated Robin Irania gutturalis

c.1,000 pairs in Iraq, also in Syria. Has bred in Lebanon.
Rufous-tailed Scrub-robin
Erythropygia galactotes
LC
Increasing?

Perhaps 5,000 pairs in Arabian Peninsula (ABBA) and spreading. 3,000+ in Iraq and some in Syria.
Black Scrub-robin
Cercotrichas podobe
LC
Increasing

500,000 pairs and increasing (ABBA); spreading northwards.

$\begin{array}{lllll}\text { Black Redstart } & \text { Phoenicurus ochruros } & \text { NT } & \text { y } & \text { D1 }\end{array}$

Breeds in Iraq (rare), Syria, Lebanon, Israel/Palestine. 100+ pairs in Iraq. Probably VU D1 but with regional adjustment $=$ LC.

Common Redstart $\quad$ Phoenicurus phoenicurus $\quad$ NT $\quad$ y $\quad$ D1

$100+$ pairs in Iraq, Syria?? Probably VU D1 but regional adjustment as common migrant.
Common Stonechat
Saxicola torquatus
LC
Stable?

60,000 pairs in Arabian Peninsula (ABBA); African Stonechat S. torquatus felix occurs in SW of region. 


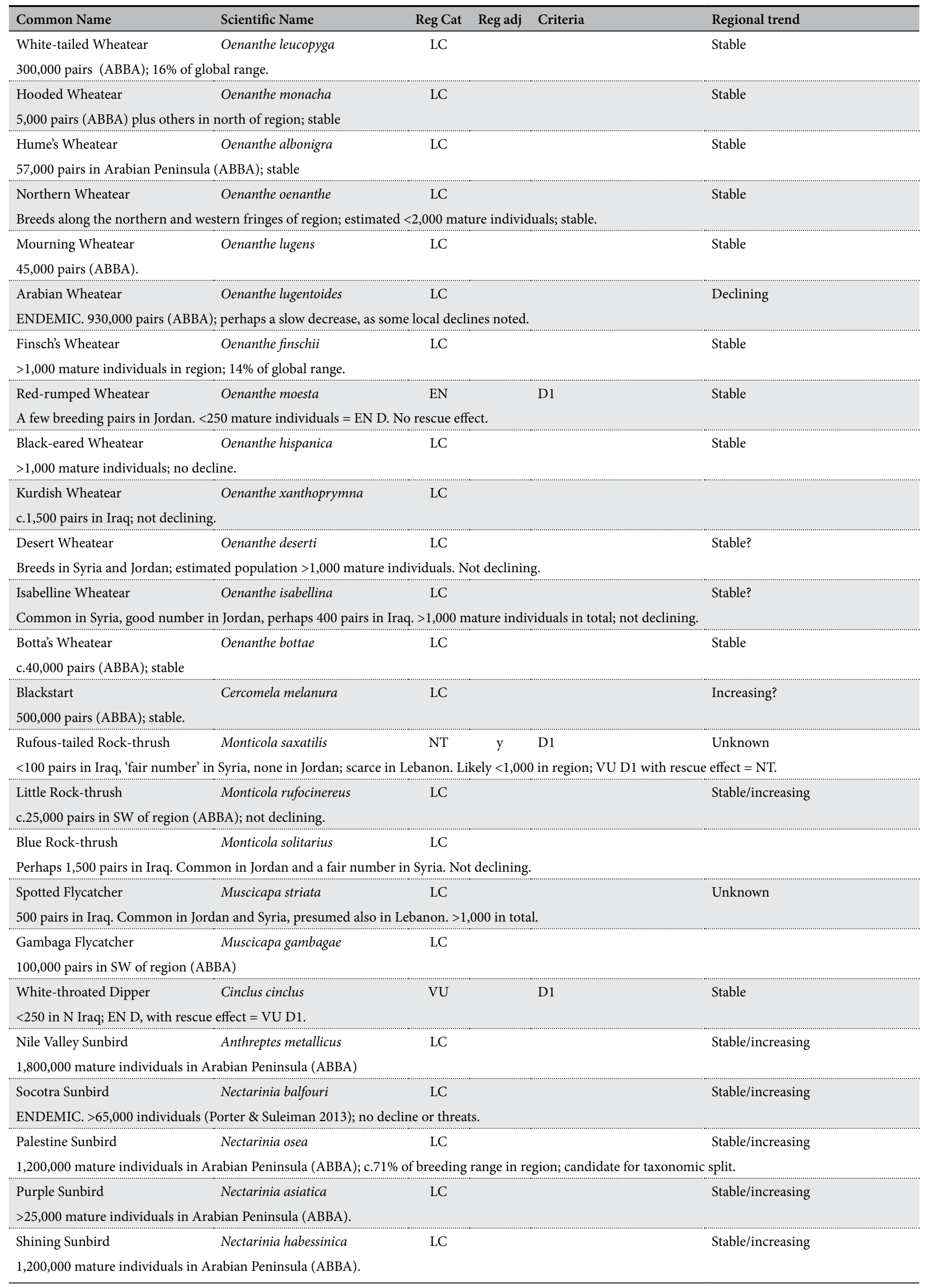




\begin{tabular}{|c|c|c|c|c|}
\hline Common Name & Scientific Name & Reg Cat Reg adj & Criteria & Regional trend \\
\hline \multicolumn{5}{|c|}{$14,000,000$ mature individuals in Arabian Peninsula (ABBA). } \\
\hline \multicolumn{4}{|c|}{ 8,000 mature individuals in Arabian Peninsula (ABBA); many more in region. } & Stable \\
\hline \multicolumn{4}{|c|}{ Numerous in Syria; may be 48,000 mature individuals in region, based on $40 \%$ of global range and global population of 120,000 . } & $\begin{array}{l}\text { Stable } \\
120,000\end{array}$ \\
\hline \multicolumn{4}{|c|}{ ENDEMIC. Over 300,000 individuals (Porter \& Suleiman 2013); widespread, no threats, stable. } & Stable \\
\hline \multicolumn{4}{|c|}{ ENDEMIC. 400 pairs (Porter \& Suleiman 2013); stable. $<1,000$ mature individuals = VU D1, no rescue effect. } & Stable \\
\hline \multicolumn{5}{|c|}{ 25,000+ pairs $(\mathrm{ABBA}) ;$ near-endemic. } \\
\hline \multicolumn{5}{|c|}{ 10,000 pairs Arabian Peninsula (ABBA) and c.1,000 pairs in Iraq. } \\
\hline \multicolumn{5}{|c|}{5,000 pairs in SW of region (ABBA); poorly known. } \\
\hline \multicolumn{5}{|c|}{ Large number in Jordan, maybe 50 pairs in Iraq, probable in Syria, also probable in Lebanon; $>1,000$ in total. } \\
\hline Pale Rock Sparrow & Petronia brachydactyla & LC & & Increasing? \\
\hline
\end{tabular}

Very nomadic, maybe increasing with increased availability of water. Breeds patchily in the region and breeding areas can vary from year to year (Porter \& Aspinall 2010). Perhaps 500,000 pairs in a good year.

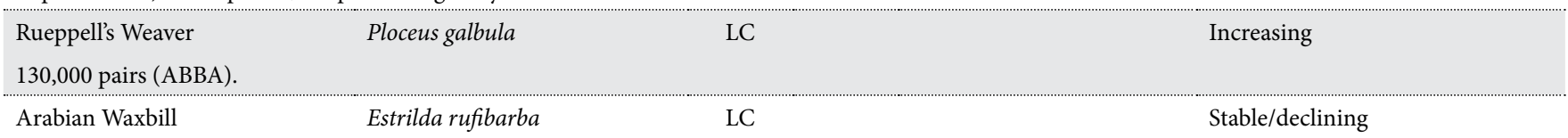

ENDEMIC. 60,000 mature individuals (ABBA). In Yemen, local declines noted, perhaps owing to lower rainfall and decreasing agriculture; in Saudi Arabia, agriculture also declining due to reduced water availability and abandoned farms cover large areas. Also under trapping pressure in Saudi Arabia for demand from Gulf countries. However, flexible, uses agricultural areas and is a prolific breeder, so can recover quickly. Declines estimated to be below the threshold for NT.

$\begin{array}{lll}\text { African Silverbill } & \text { Lonchura cantans } & \text { LC } \\ 30,000 \text { pairs }(\mathrm{ABBA}) . & \text { Lonchura malabarica } & \text { LC }\end{array}$

60,000 mature individuals in Arabian Peninsula (ABBA); 80,000 mature individuals in region. Increasing in UAE.

Yemen Accentor Prunella fagani $\quad$ NT $\quad$ C2a(ii) Declining

ENDEMIC. 1,000 pairs (ABBA). Not seen in the same densities as previously and probably under some pressure in Yemen, but seems able to live in close proximity to humans. Limited local habitat loss; habitat is naturally fragmented owing to distribution at high elevations generally (above $2,500 \mathrm{~m}$ ). Population is $<2,500$ mature individuals and possibly in decline; provisionally NT but if a continuing decline is confirmed, EN becomes appropriate under C2a(ii).

$\begin{array}{lllll}\text { Grey Wagtail } & \text { Motacilla cinerea } & \text { NT } & \text { y } & \text { D1 }\end{array}$

$<1,000$ mature individuals; VU D1 with rescue effect $=$ NT.

Richard's Pipit Anthus richardi $\quad$ VU $\quad$ D1 Stable/declining

500 pairs in SW of region (ABBA); VU D1. No rescue effect. Habitat could be in decline, but more evidence required.

\begin{tabular}{|c|c|}
\hline Tawny Pipit & Anthus campestris \\
\hline
\end{tabular}

Several hundred pairs in Syria; more along western edge; likely to be >1,000 mature individuals in region; may just qualify for NT (close to VU D1) but with rescue effect $=\mathrm{LC}$.

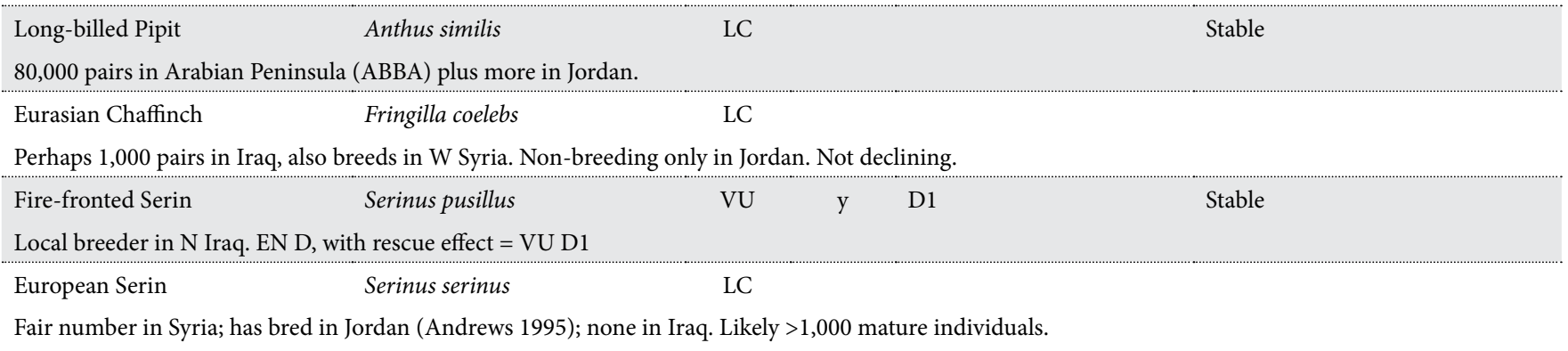




\begin{tabular}{|c|c|c|c|c|c|}
\hline Common Name & Scientific Name & Reg Cat & Reg adj & Criteria & Regional trend \\
\hline Syrian Serin & Serinus syriacus & EN & & $\mathrm{A} 2 \mathrm{acd}+\mathrm{A} 3 \mathrm{~cd}+\mathrm{A} 4 \mathrm{acd}$ & Declining \\
\hline \multicolumn{6}{|c|}{$\begin{array}{l}\text { ENDEMIC. The largest population is in Jordan; 1,000-1,200 pairs in } 1998 \text { but declined to } 500-700 \text { pairs in } 2011 \text {; Extent of Occurrence in Jordan estimated } \\
\text { at } 17 \mathrm{~km}^{2} \text { and Area of Occupancy } 2.4 \mathrm{~km}^{2} \text {. Lebanon: only occurs in the central part of the Anti-Lebanon range; occurs in } 16 \text { IBAs but only } 6 \text { have } \\
\text { confirmed breeding. Syria: one site with confirmed breeding (Bloudan) but subject to very heavy development pressure for chalets, flats, and roads and } \\
\text { habitat is declining quite sharply. Israel: } 100-300 \text { individuals were estimated on Mt Hermon in } 2000 \text {. Threats include grazing pressure, drought, trapping, } \\
\text { and destruction of habitat for development of residential areas. Declining and likely at a rate }>50 \% \text { over } 11 \text { years ( } 3 \text { generations). EN A2acd+A3cd+A4acd. } \\
\text { Close to meeting EN B2ab, but there are at least } 9 \text { locations. }\end{array}$} \\
\hline Olive-rumped Serin & Serinus rothschildi & LC & & & Declining \\
\hline
\end{tabular}

ENDEMIC. 400,000 pairs (ABBA), mainly in SW mountains; also recorded at Jeddah (near Red Sea coast) and Riyadh (not breeding)? In Yemen no decline and range may be increasing; in Saudi Arabia, nests using material from Juniper trees which are in decline; under some trapping pressure in Saudi Arabia and on sale in markets.
Yemen Serin
Serinus menachensis
LC
Stable/declining

ENDEMIC. 100,000 pairs (ABBA), mainly in SW Mountains; a small isolated population lives in a sink hole in Dhofar, south Oman. some trapping pressure. Rumours of presence in mountains near Al Mukallah in S Yemen indicates that range is discontinuous and may be a relic of earlier time. Occurs at higher elevations than S. rothschildii but is partly commensal and seen around buildings \& degraded grassland. Sometimes trapped.
Socotra Grosbeak
Rhynchostruthus socotranus
LC
Stable

ENDEMIC. 16,800 individuals (Porter \& Suleiman 2013), widespread; stable
Arabian Grosbeak
Rhynchostruthus percivali
NT
C2a(ii)
Declining

ENDEMIC. 6,000 mature individuals (ABBA); threatened by tree cutting, over-grazing etc; thought to be stable in Oman and Saudi Arabia. Taking a precautionary view, and considering declines reported in Yemen, NT C2a(ii).
European Greenfinch
Carduelis chloris
$\mathrm{LC}$
Declining

$>1,000$ mature individuals in region. Trapped a lot in Syria for sale at markets; threatened by trapping in other countries. Decline not thought to reach $20 \%$ over 3 generations.

European Goldfinch $\quad$ Carduelis carduelis $\quad$ EN $\quad$ A2bd+3d+4bd Declining

4,000 mature individuals in Arabian Peninsula (ABBA); plus Jordan, Iraq, Lebanon, Syria. High trapping pressure in Jordan and Syria and many seen for sale in markets. Suspected decline of $50-70 \%$ since 2000 ; the situation may be worse, i.e. approaching threshold for CR. EN A2bd+3d+4bd; no rescue effect as also trapped in Turkey and N Africa; marked decline around Mediterranean and wiped out from extensive areas of North Africa.

Eurasian Linnet Carduelis cannabina Stable

$>1,000$ mature individuals; not declining

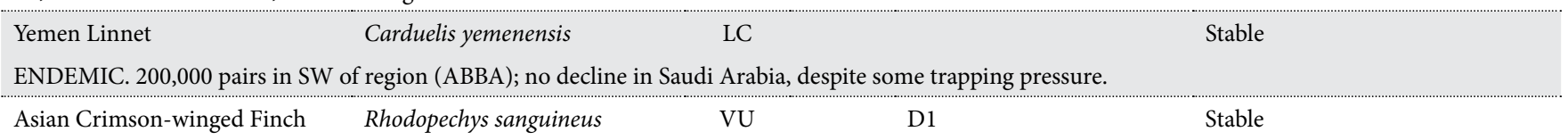

Breeds in Lebanon and possibly Syria. <1,000 mature individuals; VU D1; no significant rescue effect.

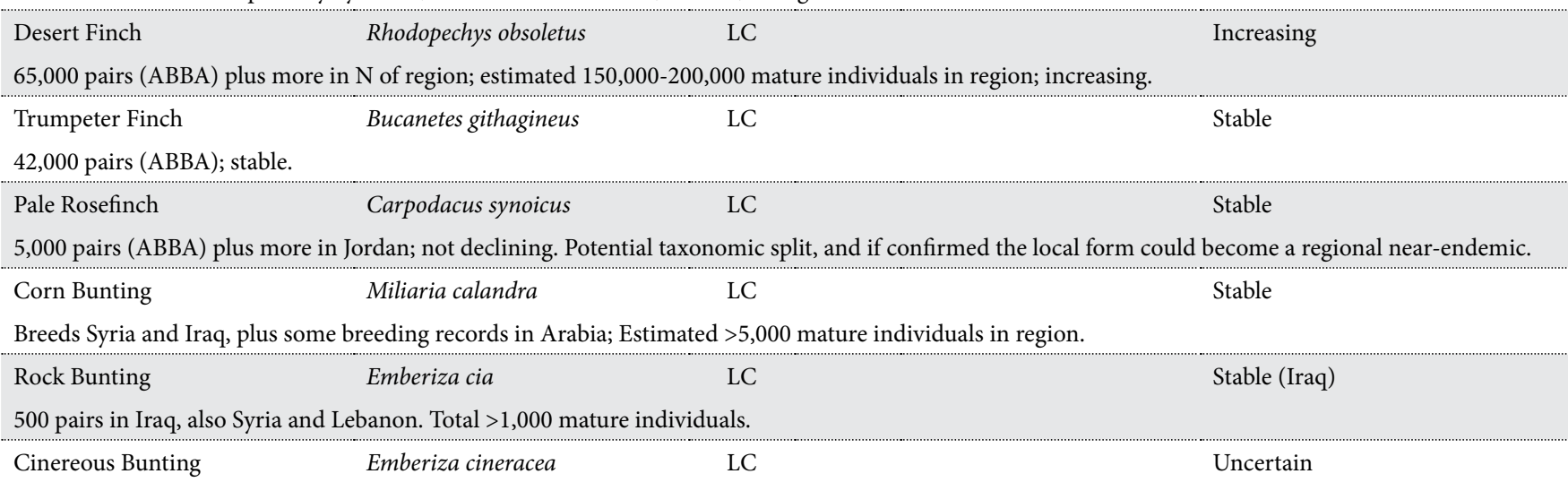

$>1,000$ pairs in Iraq. May be split as Eastern Cinereous Bunting. Globally NT, based on declines in Turkey where majority of global population.

\begin{tabular}{l} 
Ortolan Bunting $\begin{array}{c}\text { Emberiza hortulana } \\
\text { Perhaps } 500 \text { pairs in Iraq. Declining across much of world range but trend within region unknown. Precautionary VU D1, with rescue effect }=\text { NT. }\end{array}$ \\
$\begin{array}{l}\text { Cretzschmar's Bunting } \\
\text { Estimated }>1,000 \text { along the western edge of the region. }\end{array}$ \\
$\begin{array}{l}\text { House Bunting } \\
130,000 \text { pairs }(\mathrm{ABBA}) ; \text { stable. }\end{array}$ \\
\hline
\end{tabular}




\begin{tabular}{|c|c|c|c|c|c|}
\hline Common Name & Scientific Name & Reg Cat & Reg adj & Criteria & Regional trend \\
\hline Cinnamon-breasted Bunting & Emberiza tahapisi & $\mathrm{LC}$ & & & Stable \\
\hline \multicolumn{6}{|l|}{$1,000,000$ pairs (ABBA); stable. } \\
\hline Socotra Bunting & Emberiza socotrana & NT & & $\mathrm{B} 1+2 \mathrm{ab}$ & Stable \\
\hline \multicolumn{6}{|c|}{$\begin{array}{l}\text { ENDEMIC. Estimated 3,770 individuals (Porter \& Suleiman 2013); } 2 / 3 \text { of this is } 2,600 \text { mature individuals; nests in highlands - no appreciable threats; } \\
\text { lowland birds slightly affected by road construction. Meets size criterion for B1 and B2 but not declining - NT. }\end{array}$} \\
\hline
\end{tabular}

Occurs along the western edge of the region and in northern Iraq; estimated >1,000 mature individuals.

\section{MARGINAL SPECIES NOT APPLICABLE (NA) FOR ASSESSMENT}

Great Bittern Botaurus stellaris NA

Historical breeding record from Iraq; may breed in southern marshes (Salim et al. 2012) but no confirmed recent records.

$\begin{array}{lll}\text { Common Shelduck } & \text { Tadorna tadorna } & \text { NA } \\ \text { Very few pairs. Marginal. } & & \text { NA } \\ \text { Mallard } & \text { Anas platyrhynchos } & \text { NA }\end{array}$

Mallard Anas platyrhynchos NA

Believed to be feral in Arabia. No historical records in Iraq, now $<10$ pairs there. Marginal.

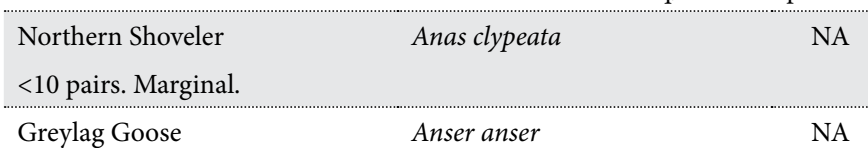

Historical breeder in S Iraq - last confirmed in 1960s. 2009 report of a nest in 2009 from reliable hunters but needs confirmation. Marginal.
Black-necked Grebe
Podiceps nigricollis
NA
Very local and irregular breeder in central Iraq; probably breeds in Syria. $0.07 \%$ of global range in region; Irregular breeder; $<50$ pairs.
Booted Eagle
Hieraaetus pennatus
NA
Stable?

$<100$ mature individuals breed in N Iraq. 0.1\% GR. Marginal.

Eurasian Hobby Falco subbuteo $\quad$ NA

Few in Jordan; probably breeds in Syria (Murdoch and Betton 2008). Marginal.

Great White Pelican Pelecanus onocrotalus NA

One pair bred in Syria in 2011. One recent breeding record from Kuwait. Marginal.

Baillon's Crake Porzana pusilla NA

Only sporadic breeding records. Marginal

Spotted Crake Porzana porzana NA

Only sporadic breeding records. Marginal.
Greater Painted-snipe
Rostratula benghalensis
NA

Only 1 breeding record from Israel - marginal.

Yellow-legged Gull Larus michahellis NA

Breeds in Syria. Marginal.

Sandwich Tern Sterna sandvicensis NA

20 nesting on saline flats inland in Syria since 2009; One breeding record in Arabian Peninsula; marginal, but interesting inland record and far from nearest colony.

Long-eared Owl Asio otus NA

First breeding record in Iraq 2011. Marginal.

Eurasian Nightjar $\quad$ Caprimulgus europaeus $\quad$ NA

Only breeds in northern Iraq. Marginal.

Lesser Spotted Woodpecker Dendrocopos minor NA

Northern Iraq only. $0.029 \%$ GR. Marginal.

Eurasian Green Woodpecker $\quad$ Picus viridis $\quad$ NA $\quad$ Uncertain

Only mountains of northern Iraq (c.100 pairs). Marginal.

Red-backed Shrike Lanius collurio NA

A few in western hills; probably breeds in Syria (Murdoch \& Betton). Marginal.

Lesser Grey Shrike Lanius minor NA

Syria - probably breeding (Murdoch and Betton 2008). Marginal. 


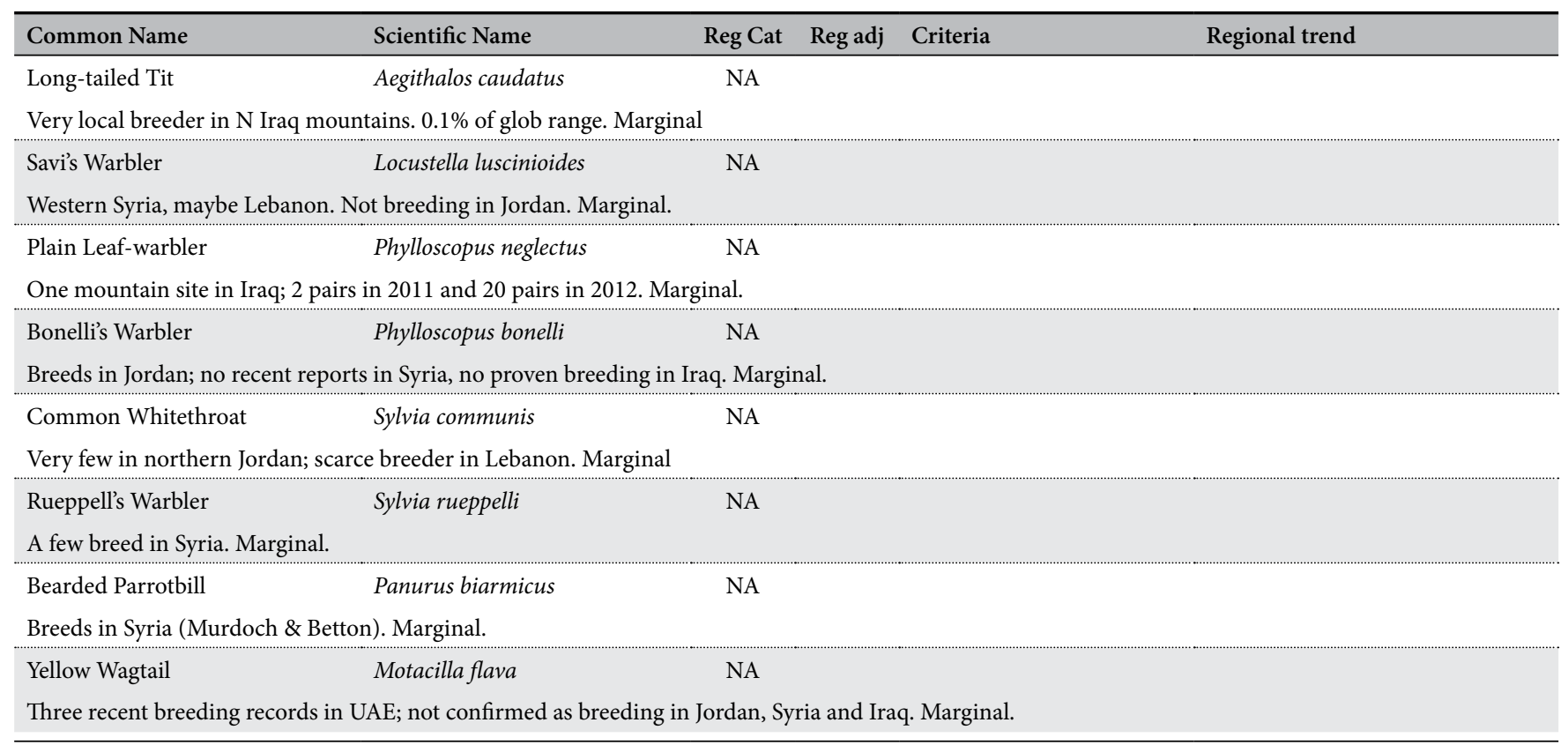




\section{Appendix 3. Endemic, near-endemic and threatened species distribution maps}

Arabian Partridge Alectoris melanocephala
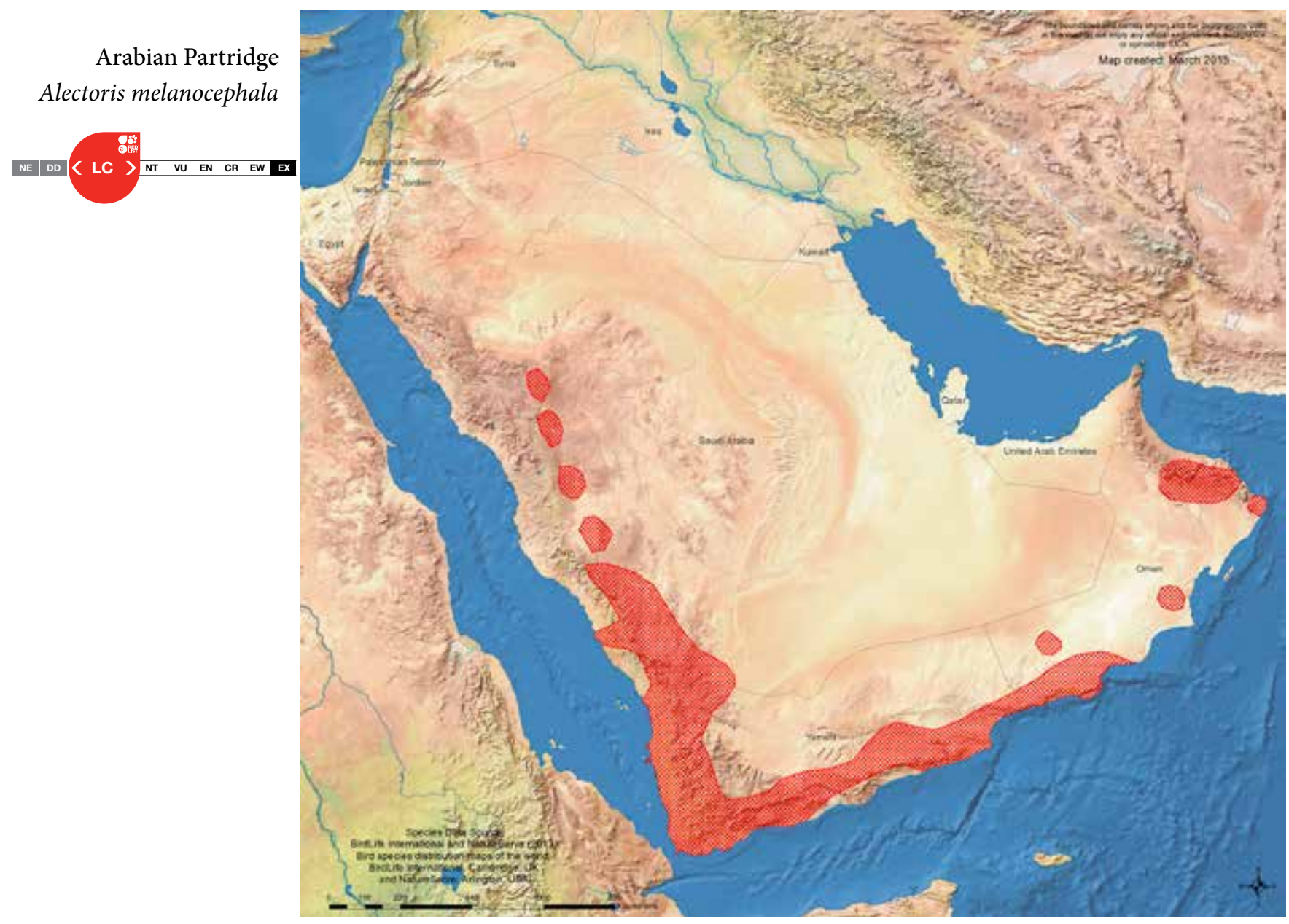

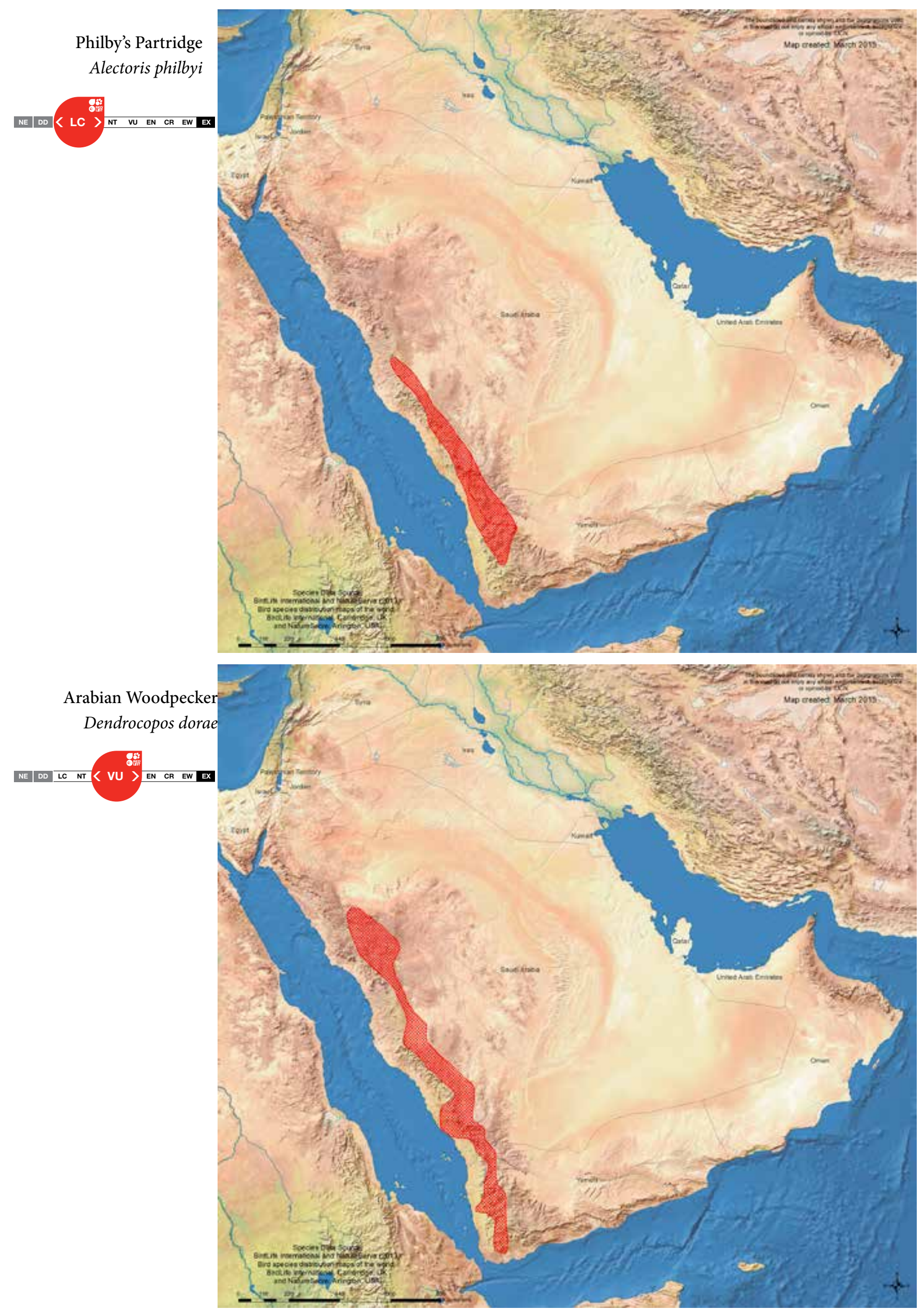

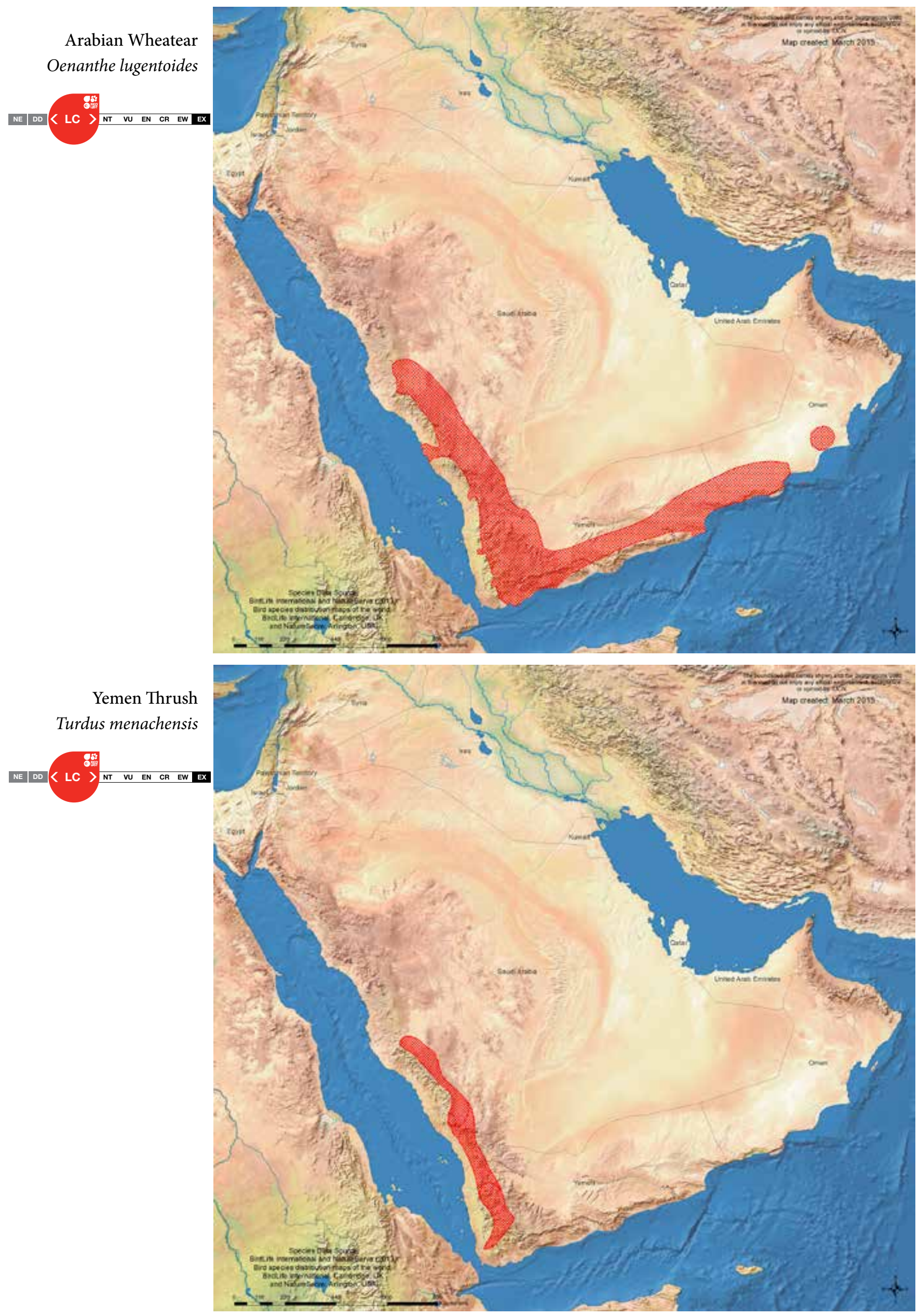

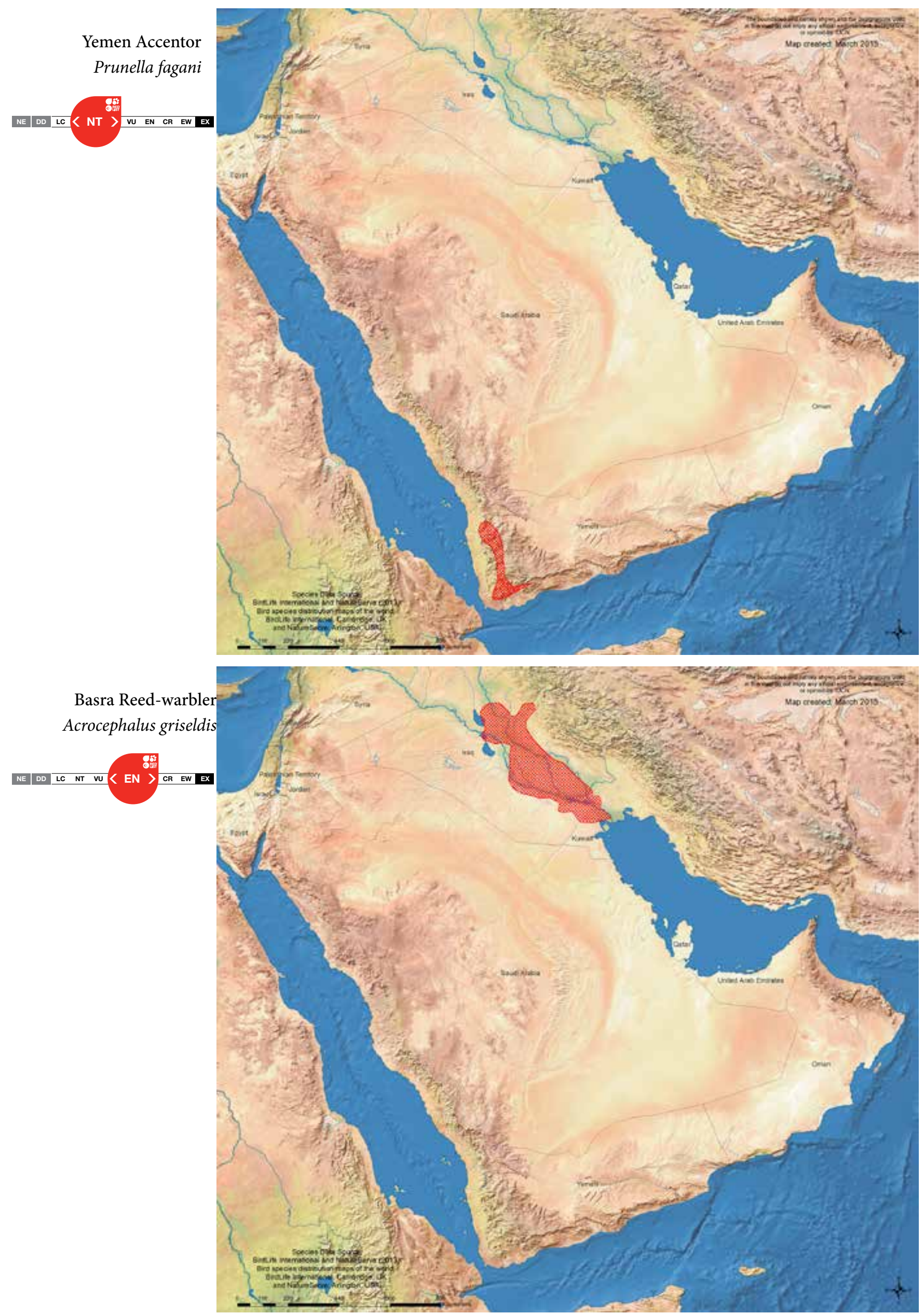

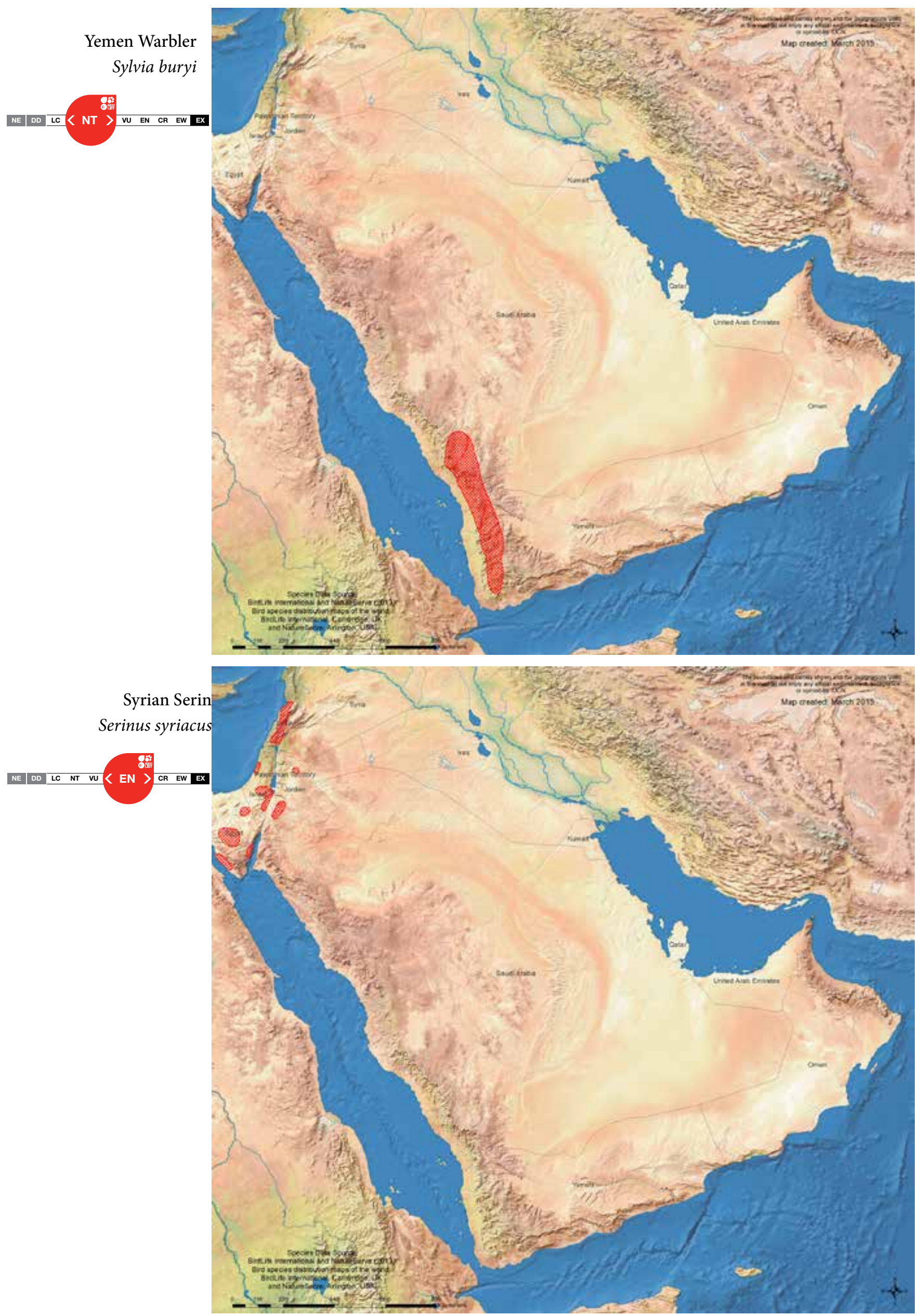

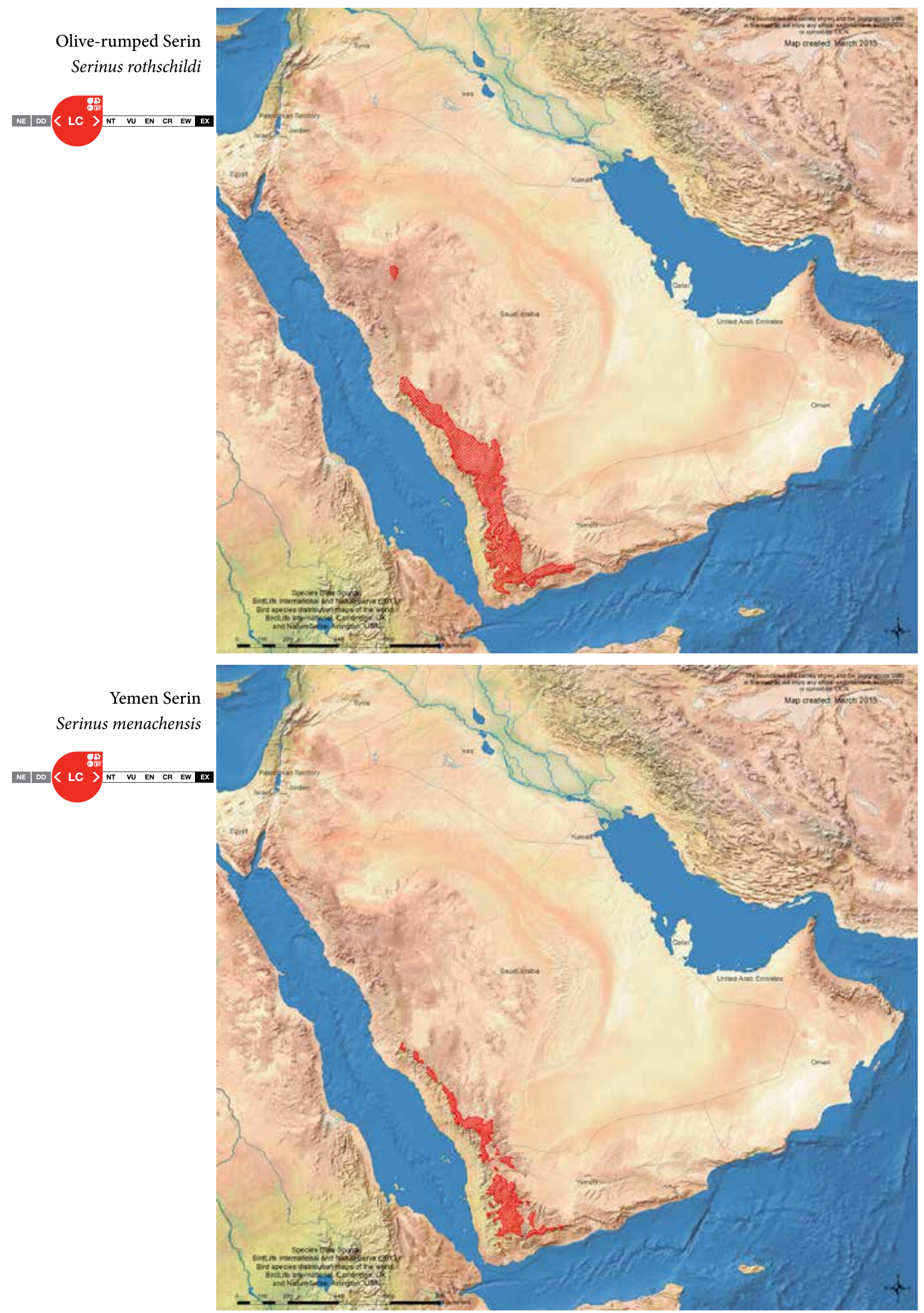

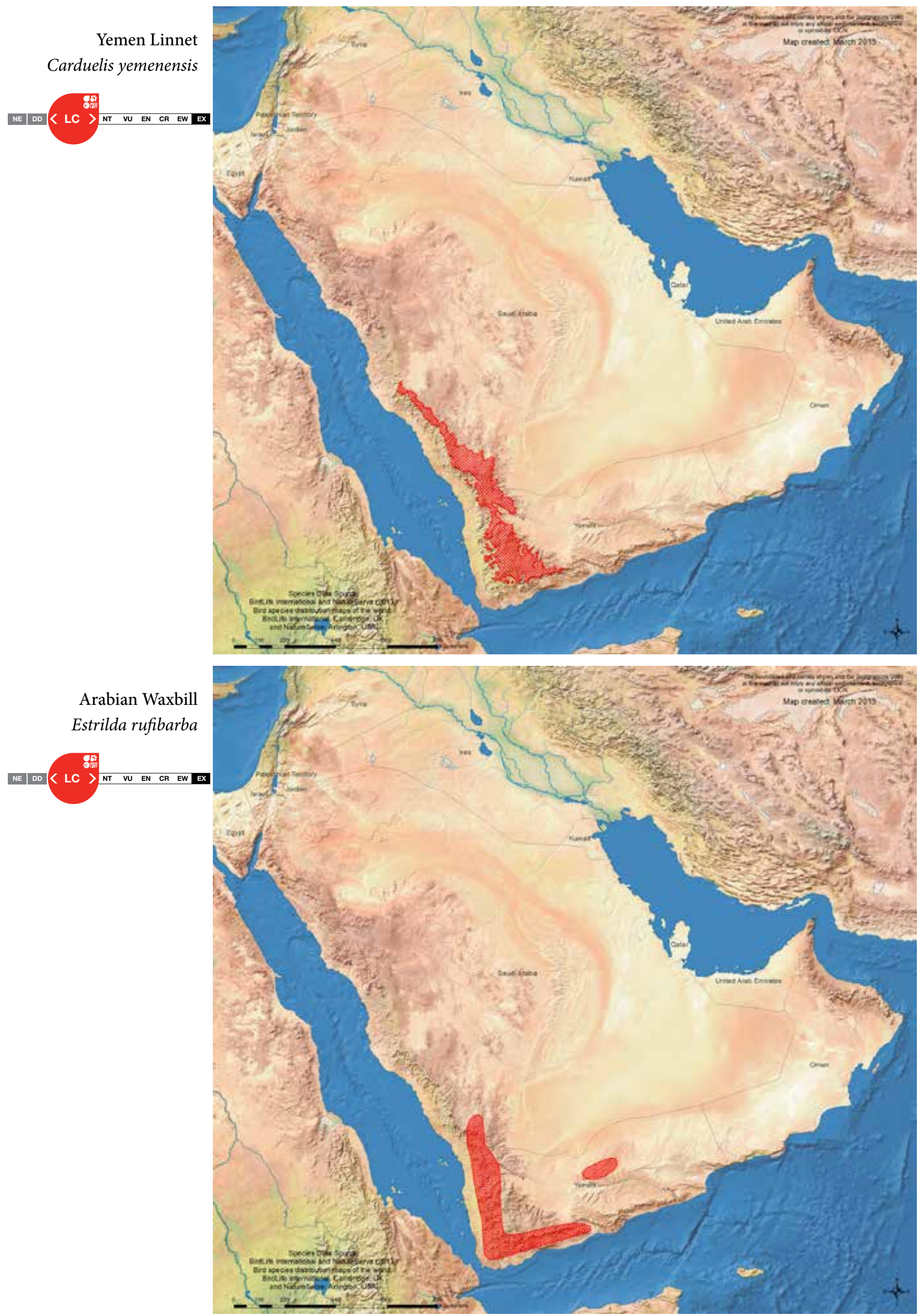


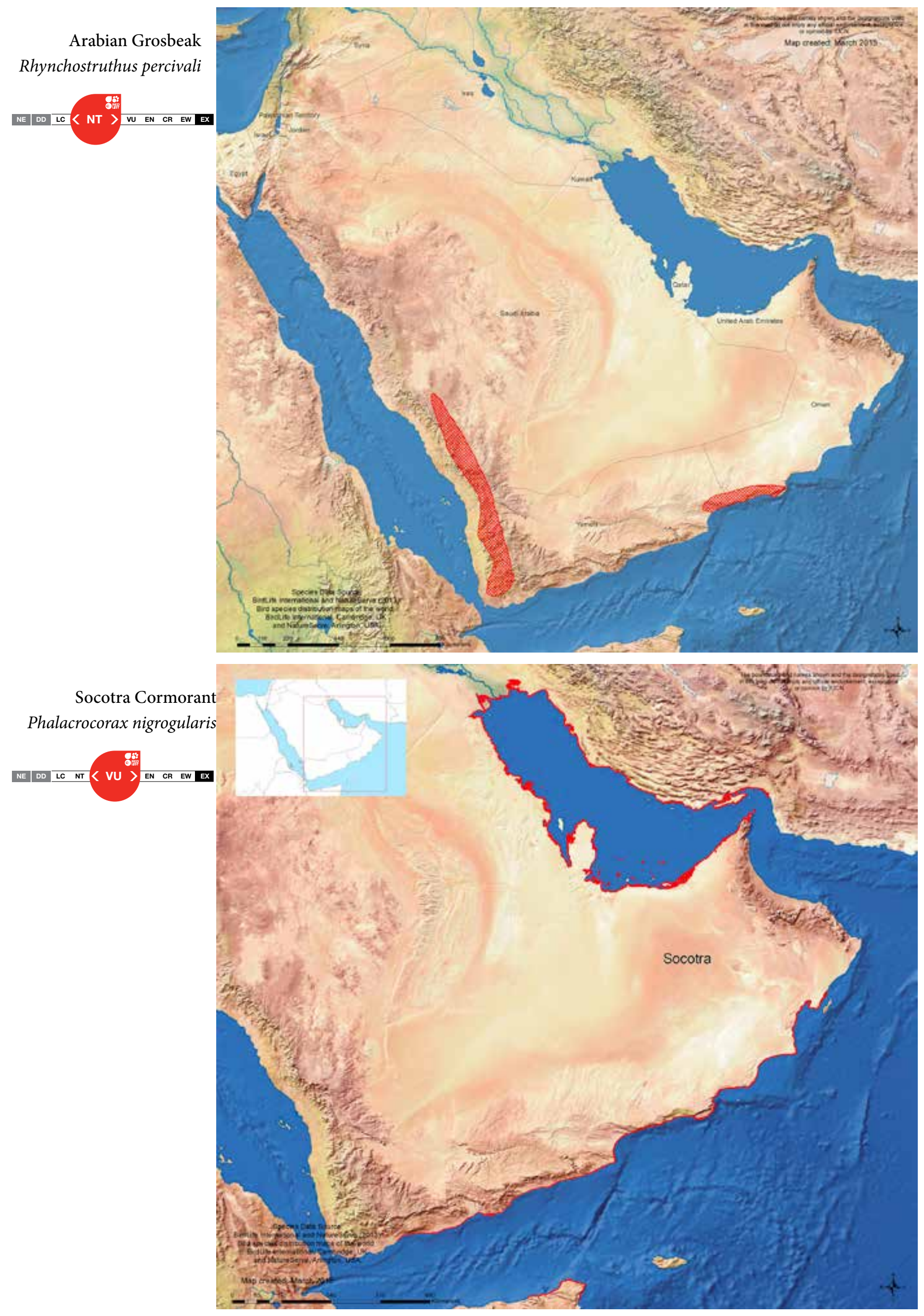



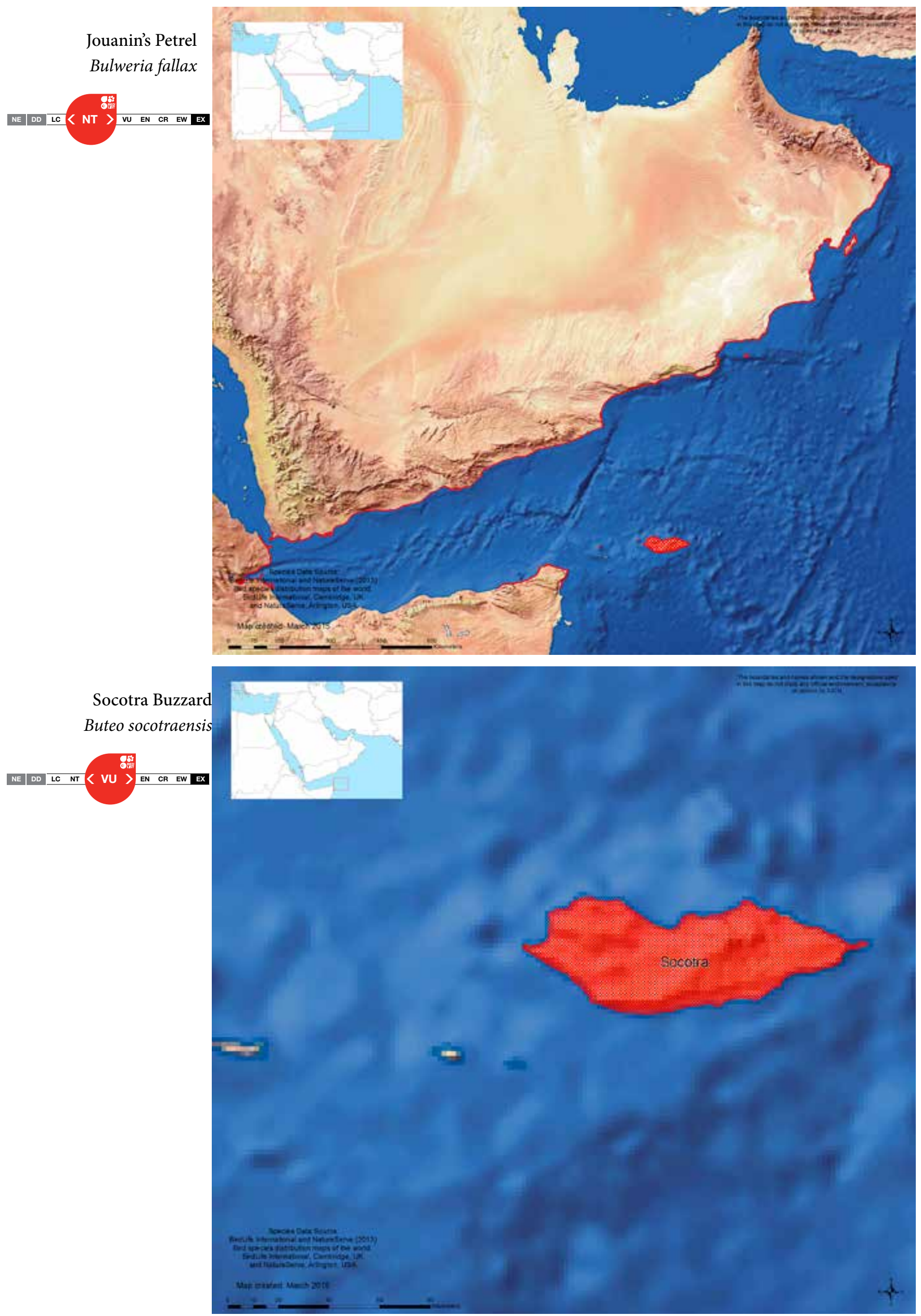
Socotra Starling Onychognathus frateri
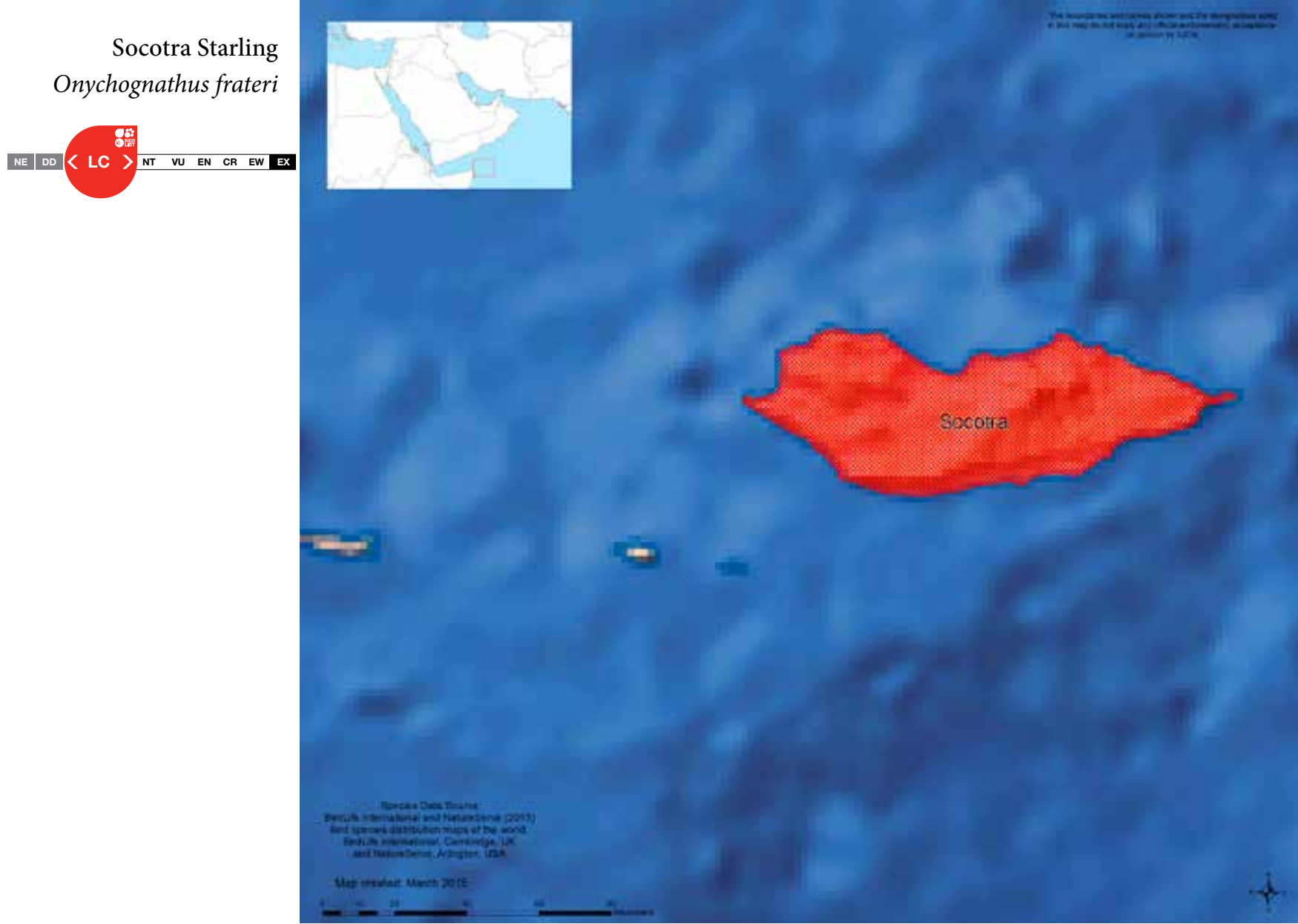

Socotra Sunbird

Nectarinia balfouri
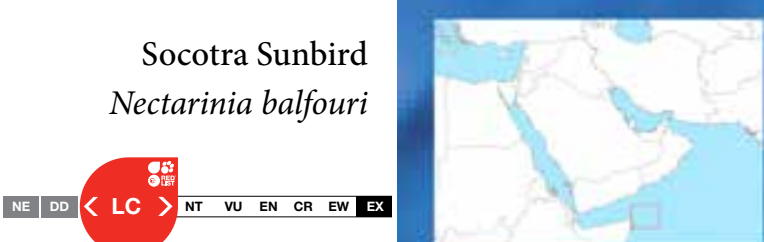

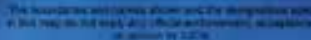

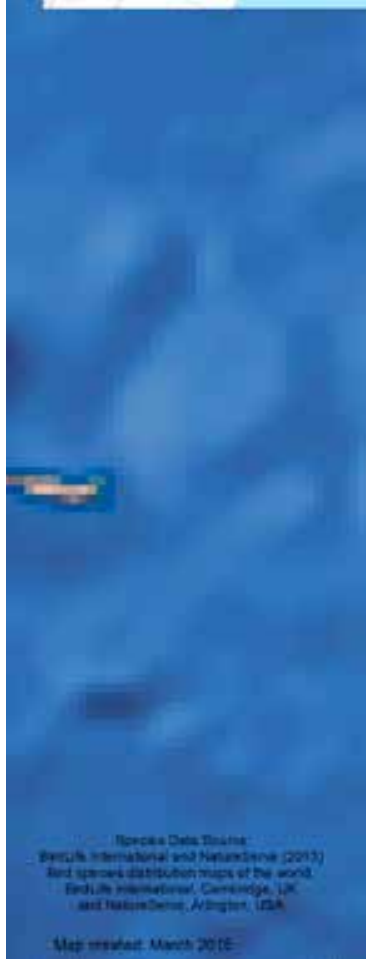

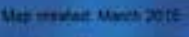

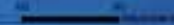


Island Cisticola

Cisticola haesitatus
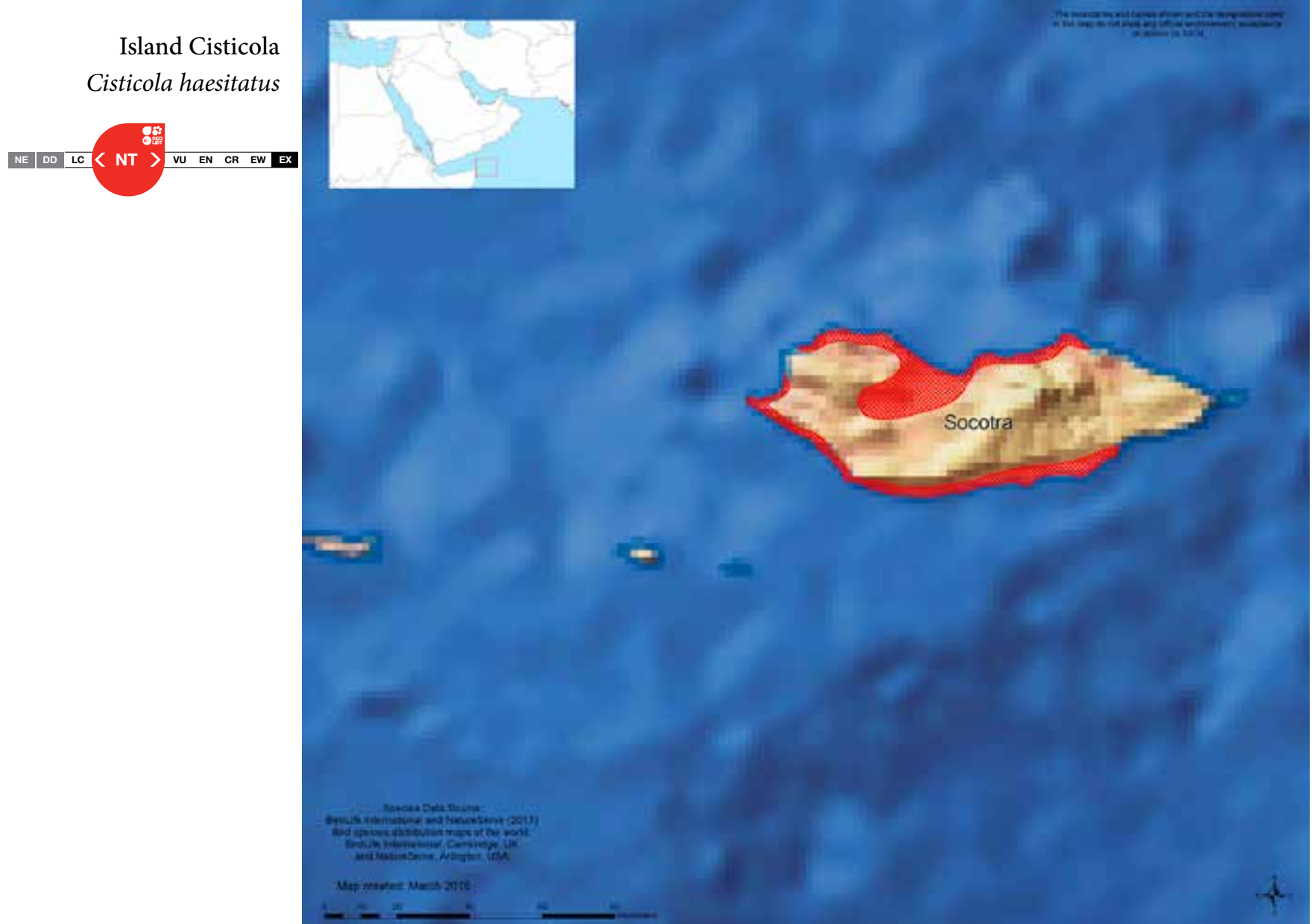

Socotra Warbler

Incana incana
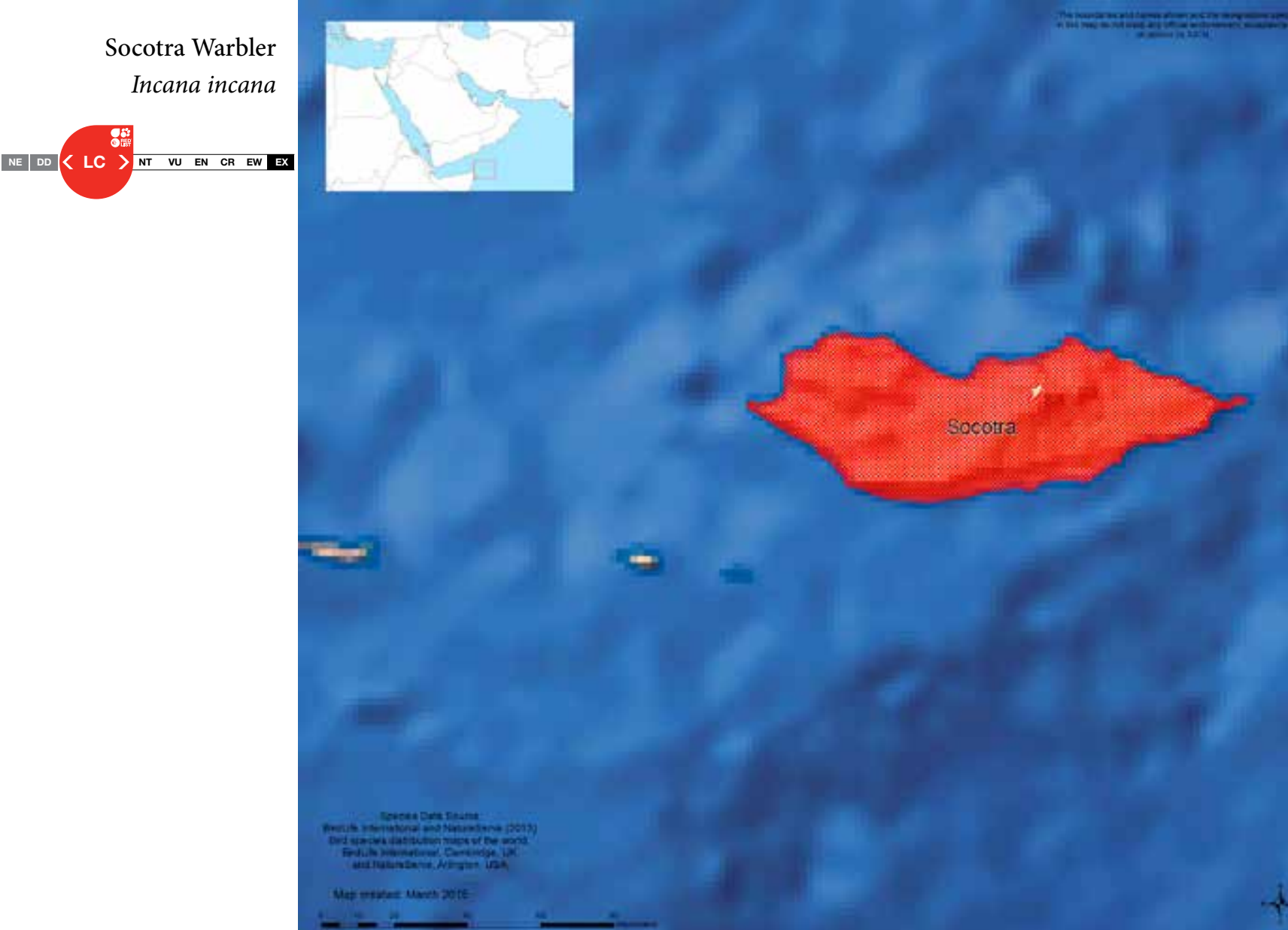

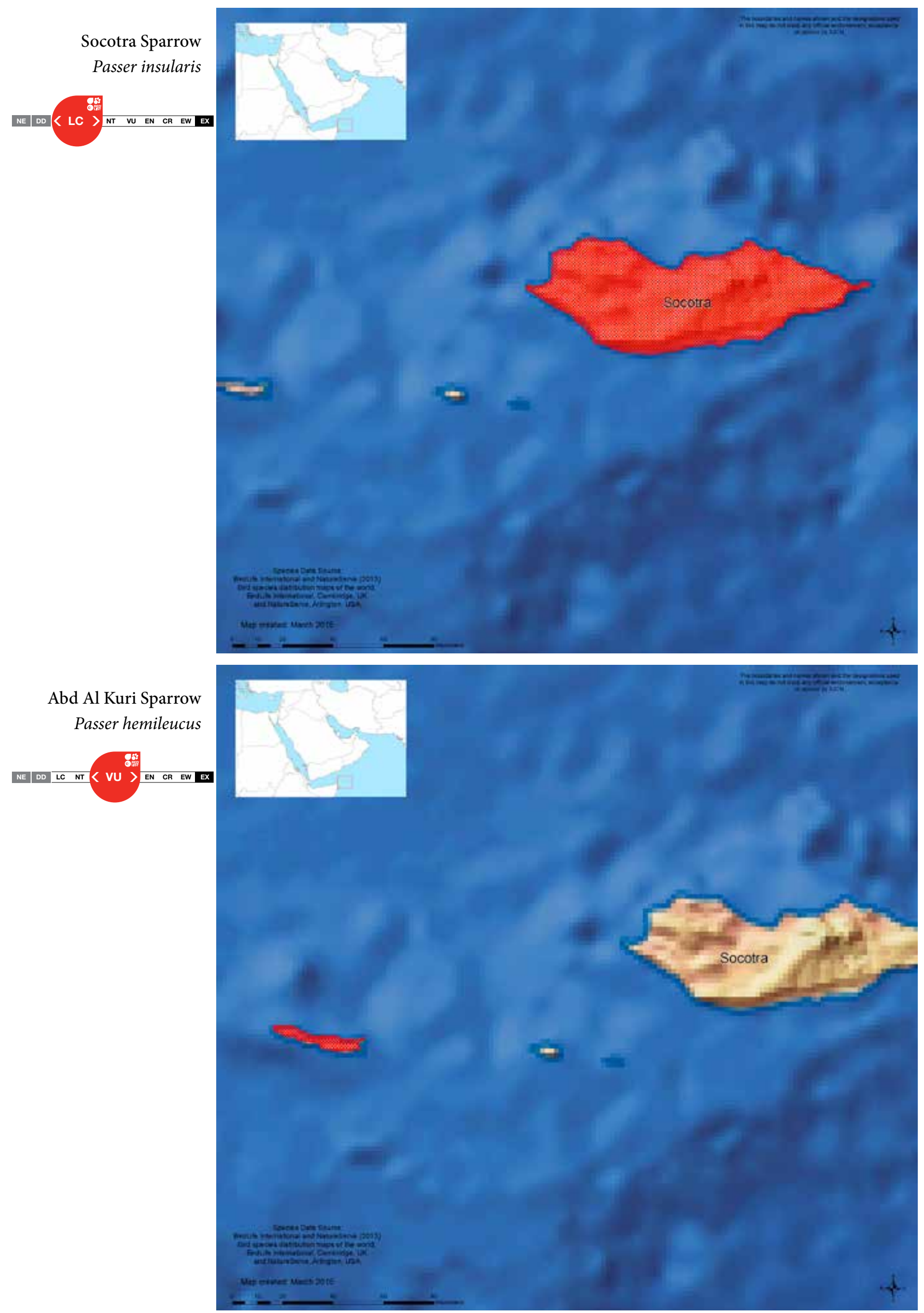
Socotra Grosbeak Rhynchostruthus socotranus
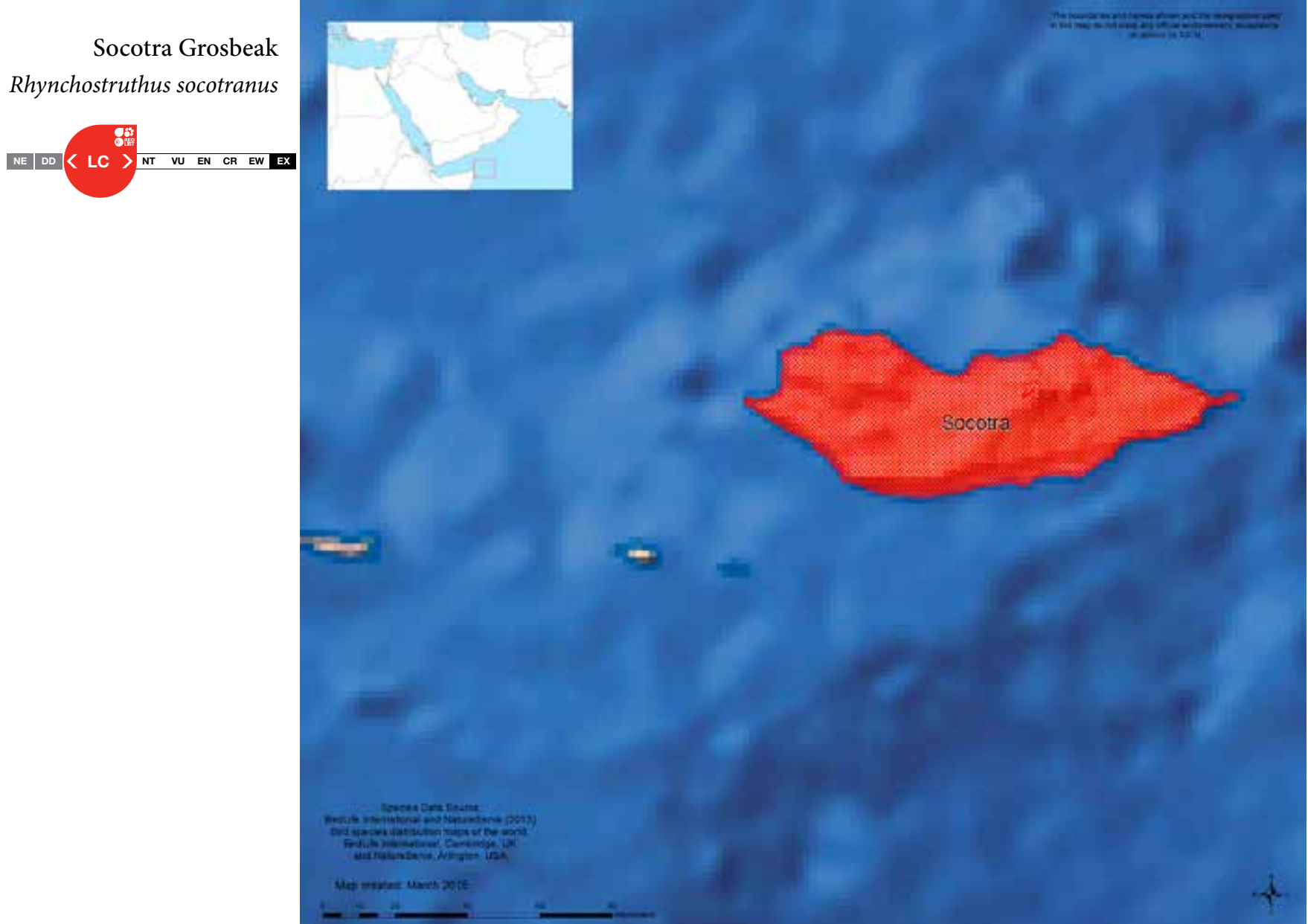

Socotra Bunting Emberiza socotrana
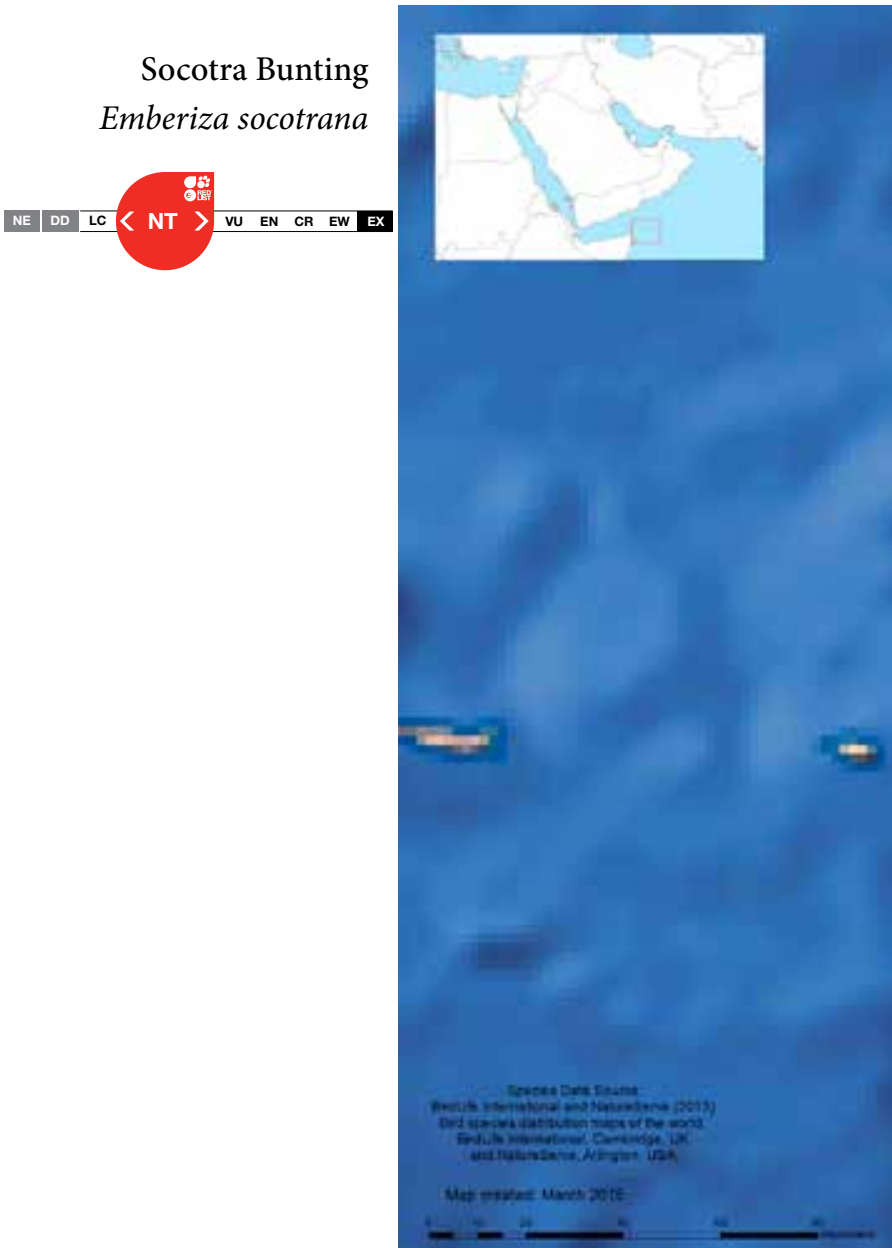

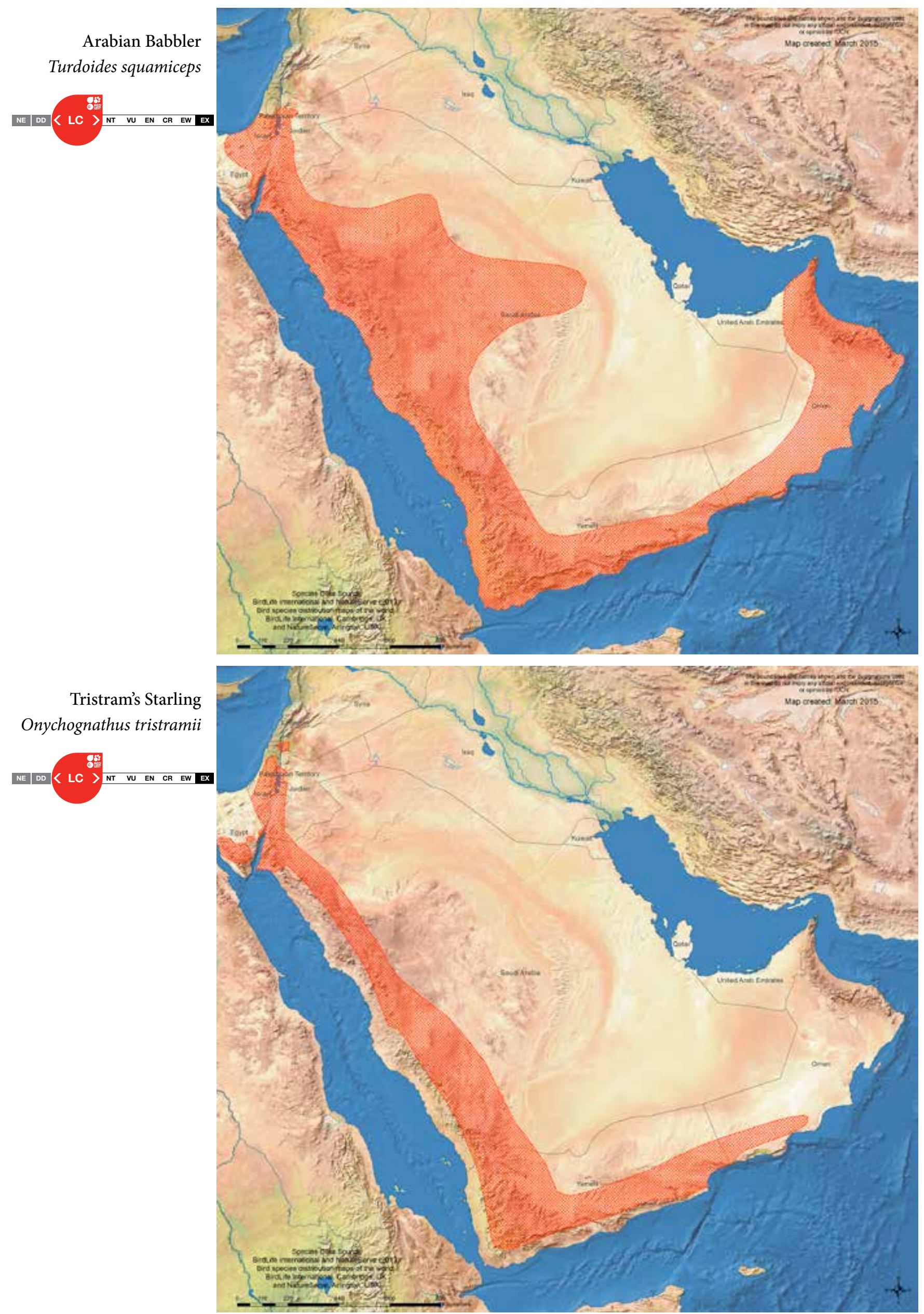


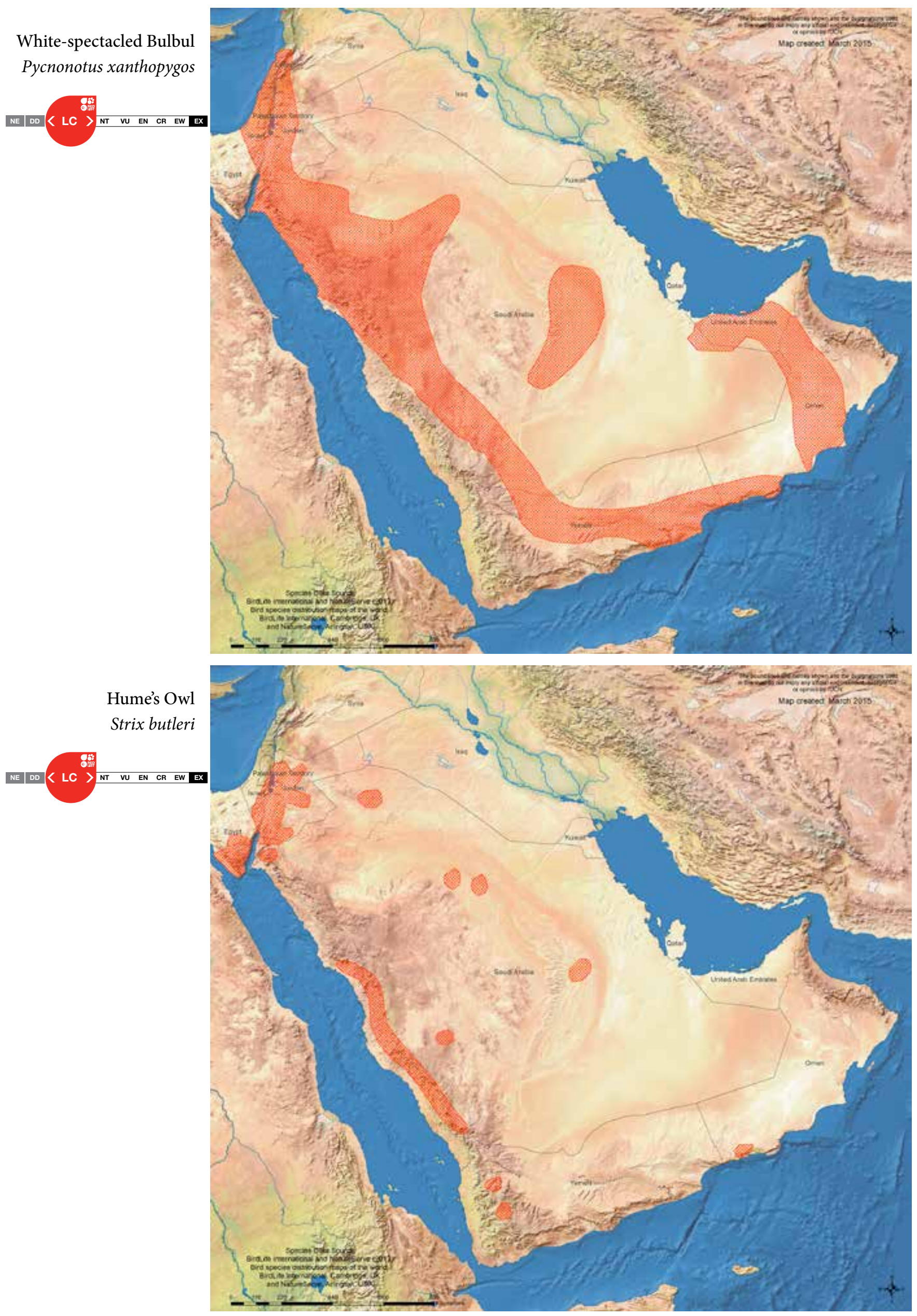



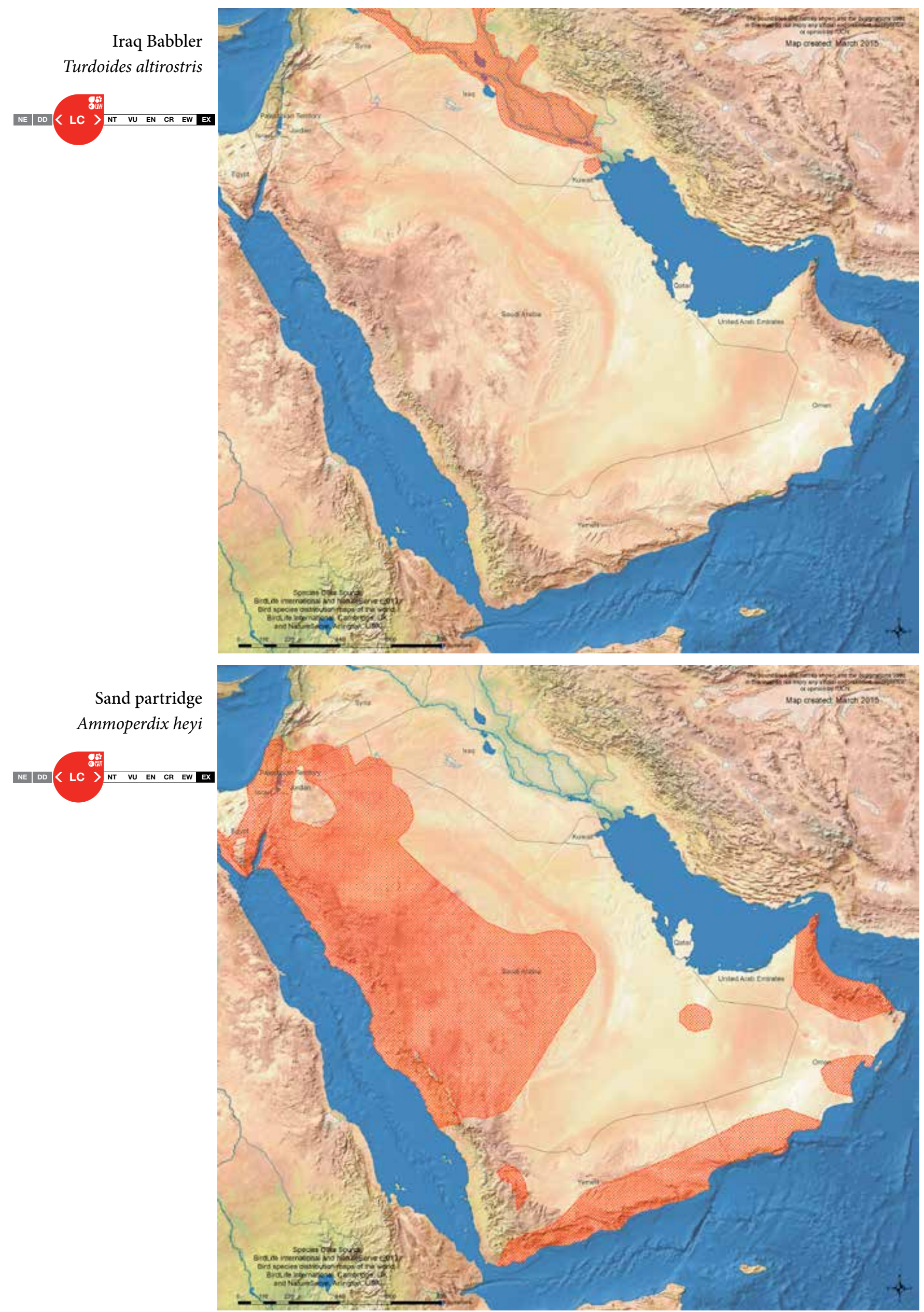

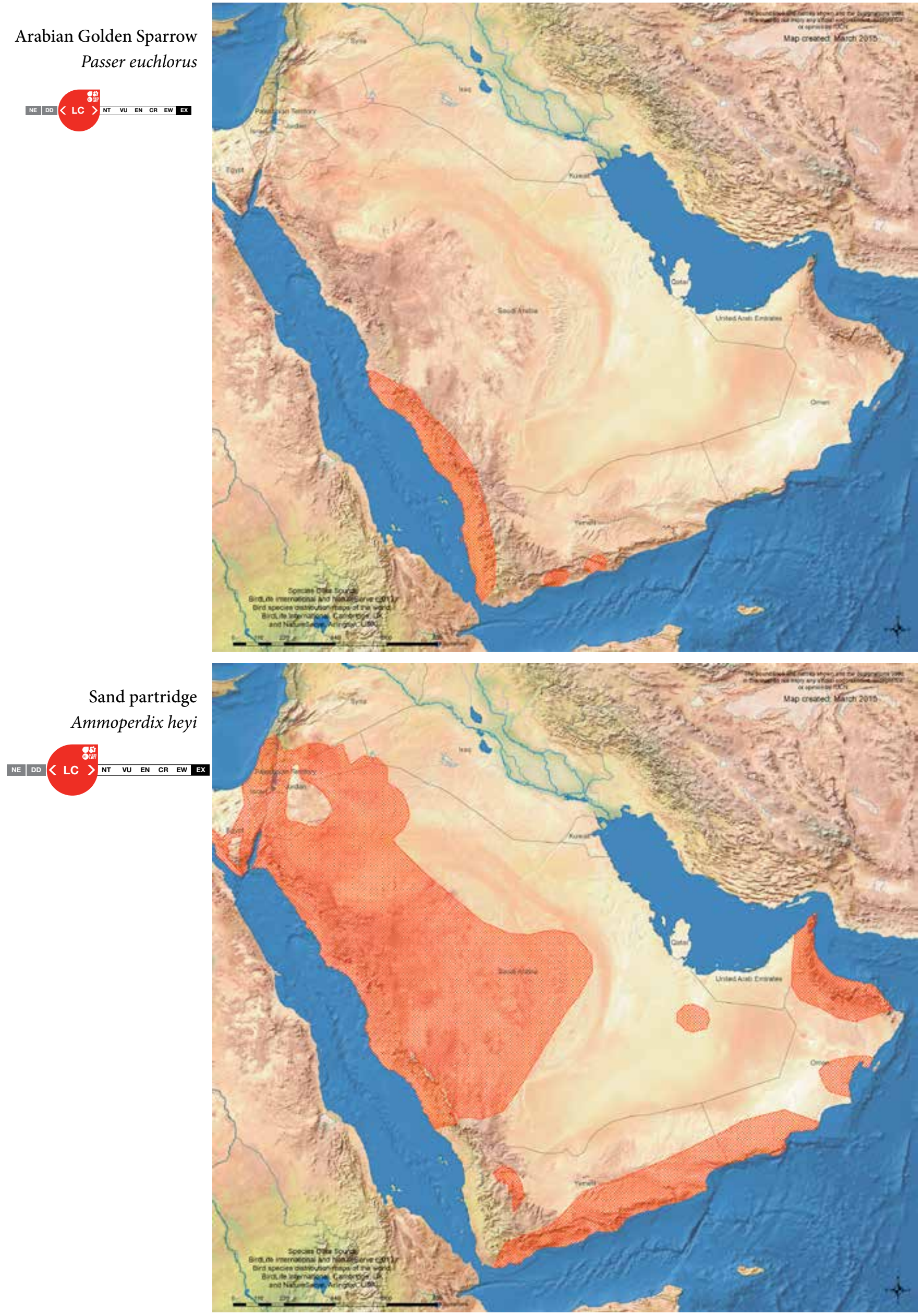

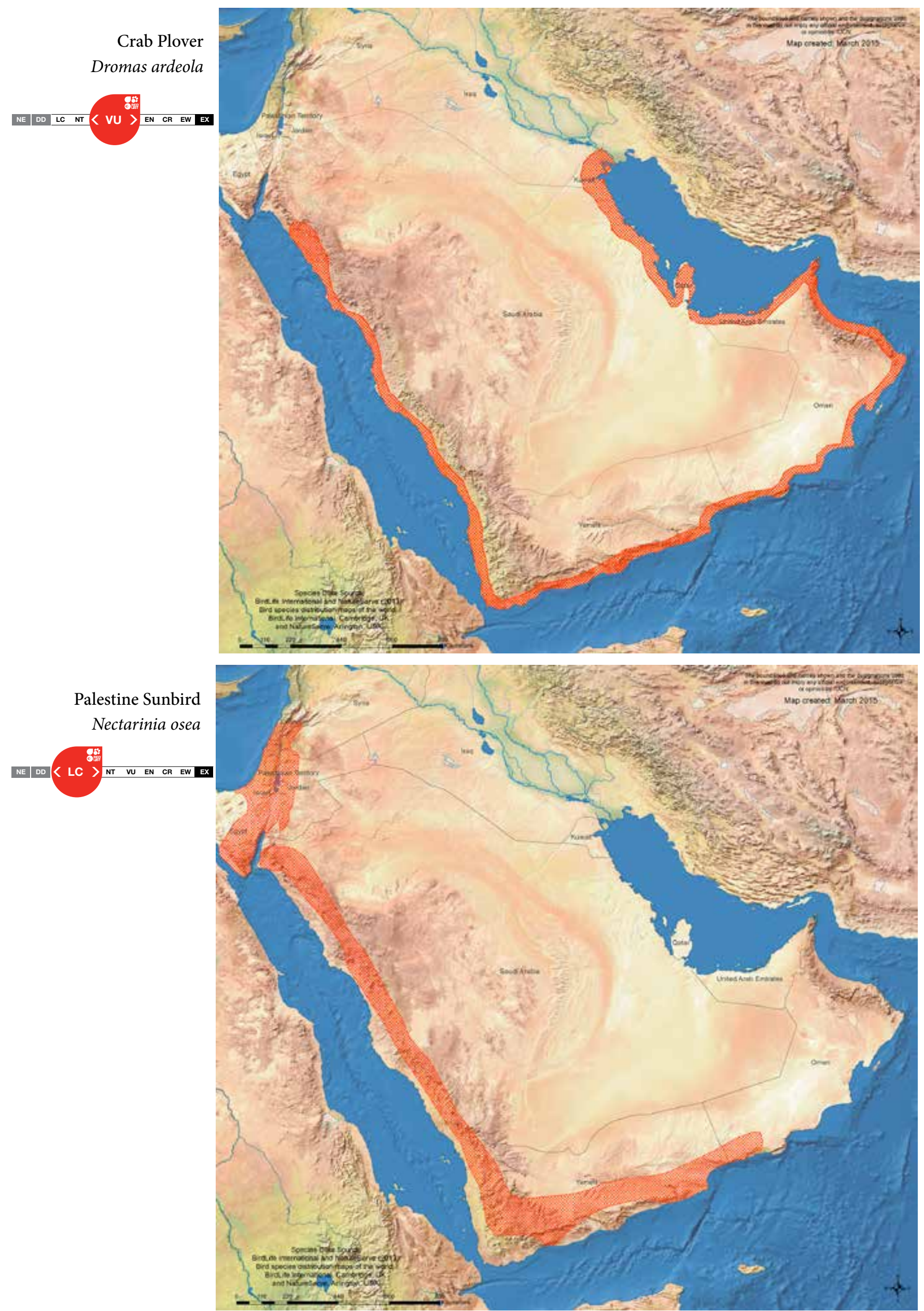


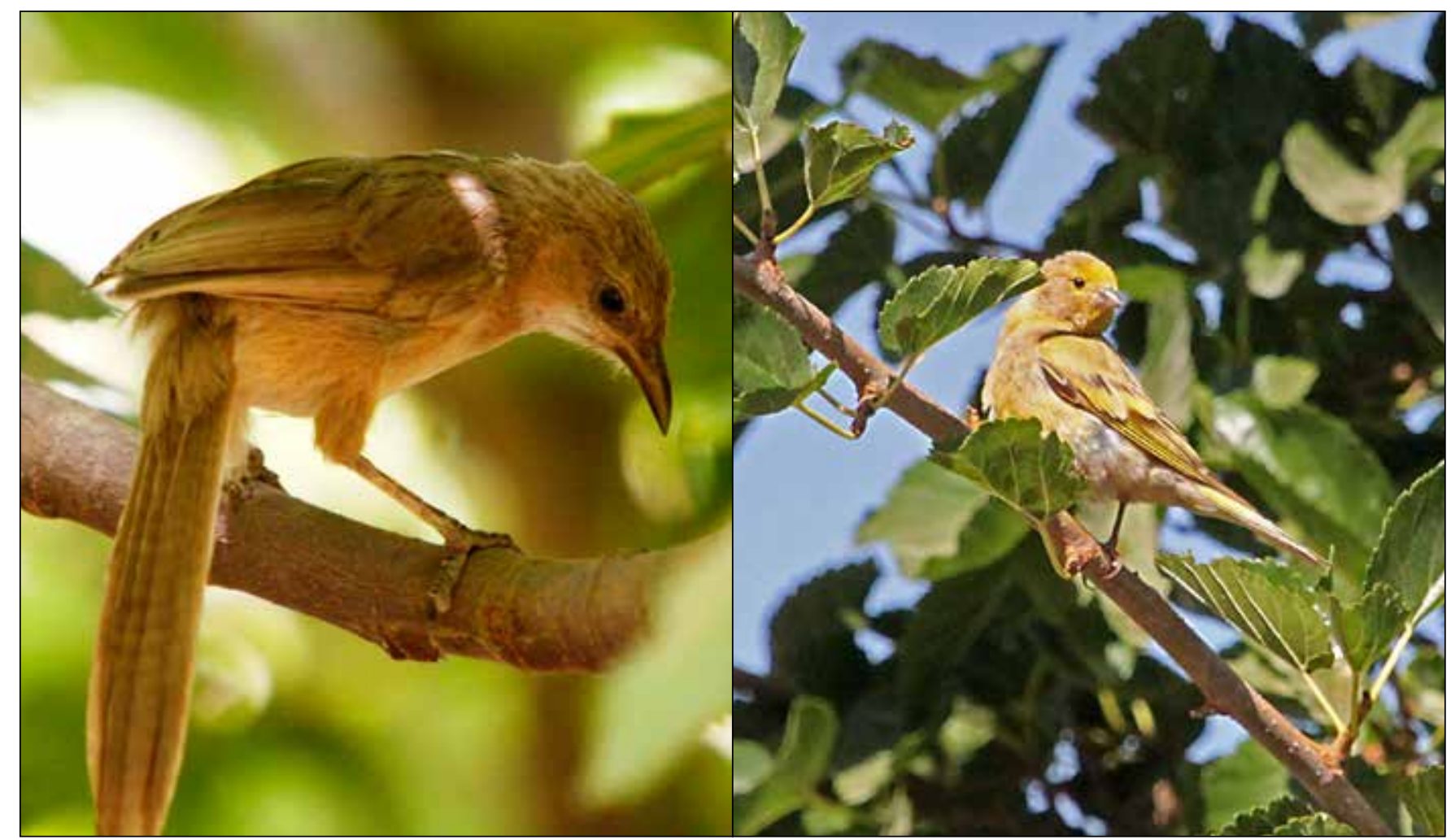

Iraq Babbler Turdoides altirostris. @ Mudhafar Salim

Syrian Serin Serinus syriacus. @ Ghassan Jarai/SPNL

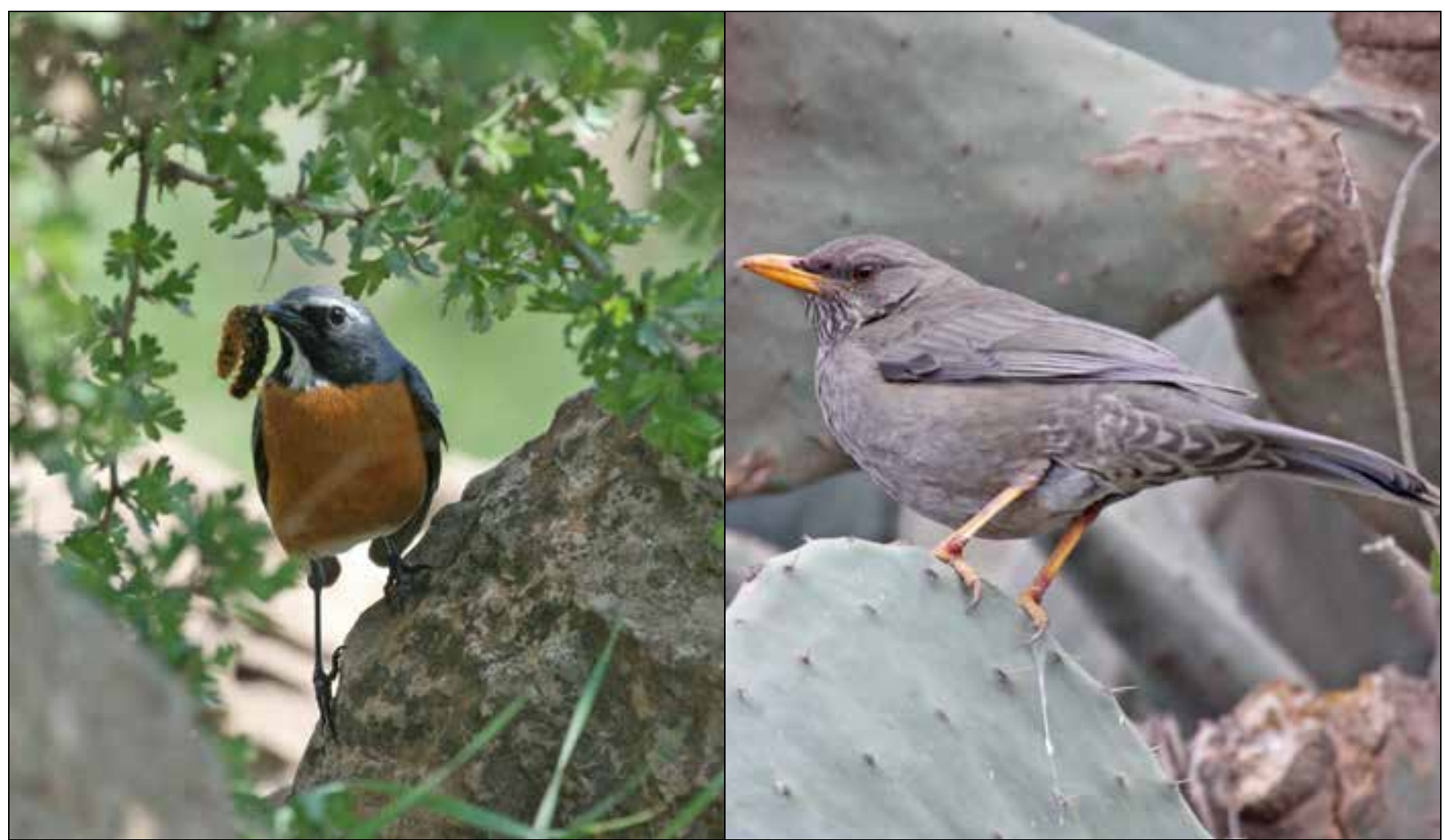

White-throated Robin Irania gutturalis. @ Richard Porter

Yemen thrush Turdus menachensis. @ Richard Porter 



\section{$9 \%$ C. Rist}

THE IUCN RED LIST
OF THREATENED SPECIES"

INTERNATIONAL UNION FOR CONSERVATION OF NATURE

WORLD HEADQUARTERS

Rue Mauverney 28

1196 Gland

Switzerland

Tel: +41229990000

Fax: +41229990020

www.iucn.org/species

www.iucnredlist.org

\section{2}

\section{Birdlife \\ INTER NATIONAL.}

\section{BIRDLIFE GLOBAL OFFICE}

WORLD HEADQUARTERS

Wellbrook Court, Girton Road

Cambridge, CB3 ONA

United Kingdom

Tel: +44 1223279837

Fax: +44 1223277200

www.birdlife.org

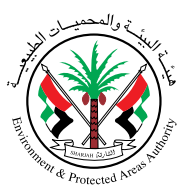

ENVIRONMENT AND PROTECTED AREAS AUTHORITY

PO Box 2926, Sharjah

United Arab Emirates

Tel: +971 65311501

Fax: +971 65311419

www.epaashj.com

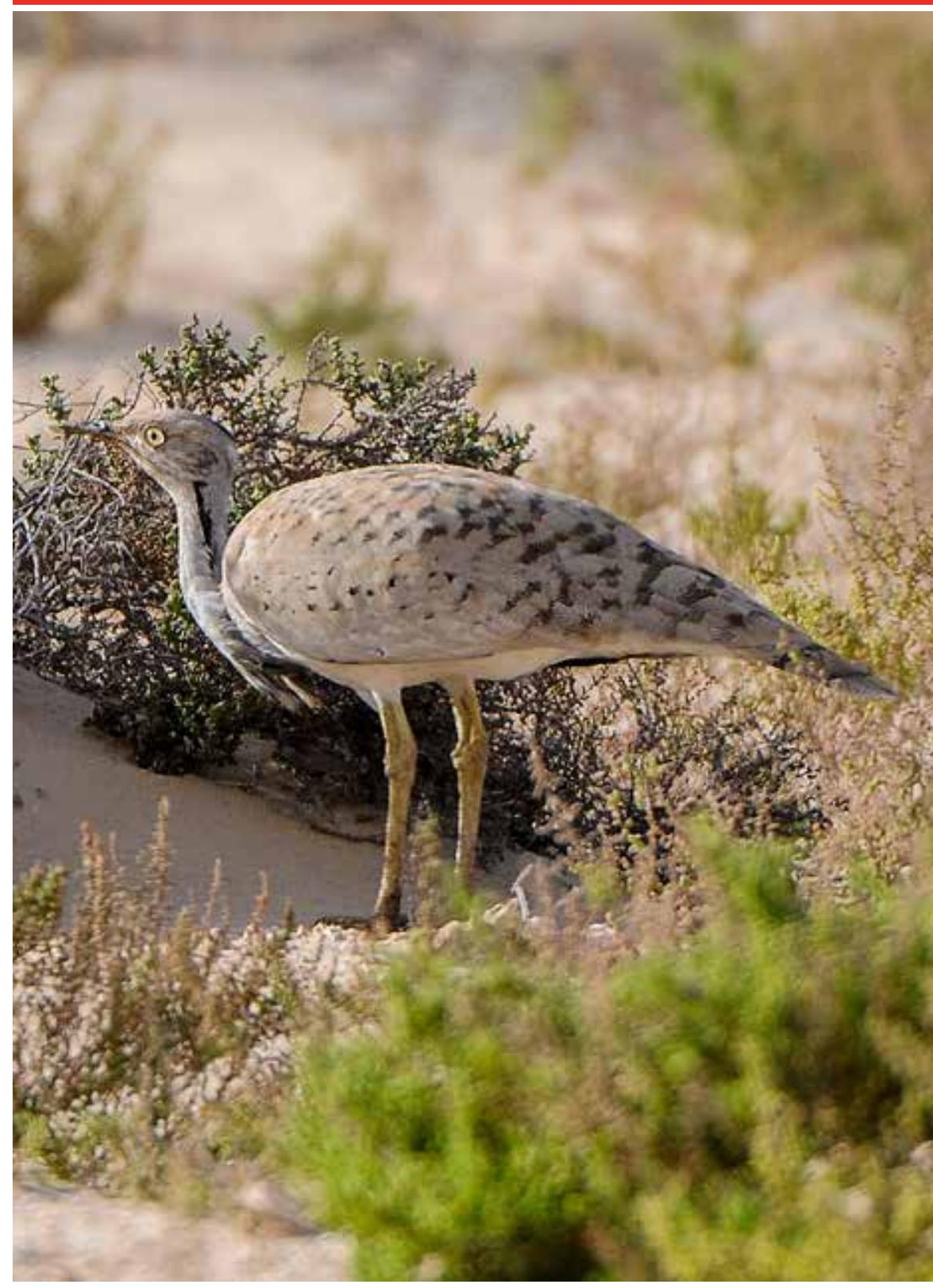

